

\section{DISCLAIMER}

Portions of this document may be illegible in electronic image products. Images are produced from the best available original document. 


\section{NOTICE}

This report was prepared as an account of work sponsored by the United States Government. Neither the United States nor the U.S. Department of Energy (DOE), nor any of its employes, nor any of its contractors, subcontractors or their employes, makes any warranty, expressed or implied, or assumes any legal liability or responsibility for any third party's use or the results of such use of any information, apparatus, product or process disclosed in this report, or represents that its use by such third party would not infringe privately owned rights.

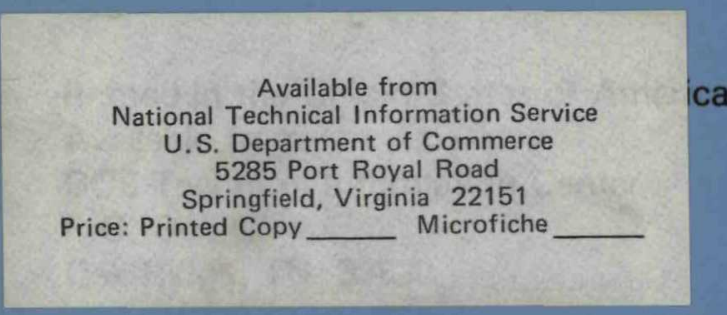

NTIS price codes

Printed Copy: A06

Microfiche copy: A01 


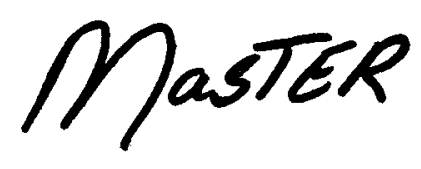

\title{
INTERMEDIATE-SCALE SODIUM-CONCRETE REACTION TESTS WITH BASALT AND LIMESTONE CONCRETE
}

\section{Hanford Engineering Development Laboratory}

\author{
J.A. Hassberger \\ L.D. Muhlestein \\ January 1981
}


-

ii 
HEDL-TME $79-55$

$U C-79 a, b, p$

INTERMEDIATE-SCALE SODIUM CONCRETE REACTION TEST WITH BASALT

AND LIMESTONE CONCRETE

J. A. Hassberger

L. D. Muhlestein

\begin{abstract}
Ten tests were performed to investigate the chemical reactions and rate and extent of attack between sodium and basalt and limestone concretes. Test temperatures ranged from 510 to $870^{\circ} \mathrm{C}\left(950\right.$ to $\left.1600^{\circ} \mathrm{F}\right)$ and test times from 2 to 24 hours. Sodium hydroxide was added to some of the tests to assess the impact of a sodium hydroxide-aided reaction on the overall penetration characteristics.

Data suggest that the sodium penetration of concrete surfaces is limited. Penetration of basalt concrete in the presence of sodium hydroxide is shown to be less severe than attack by the metallic sodium alone. Presence of sodium hydroxide changes the characteristics of sodium penetration of limestone concrete, but no major differences in bulk penetration were observed as compared to penetration by metallic sodium.
\end{abstract}


The authors are pleased to acknowledge the efforts of a number of individuals who were instrumental in planning, performing and documenting these experiments. Vince Cook, lead technician for the 105-DR facility, with his associates George MacDonald and Frank Carvo, prepared and performed the tests. R.W. Wierman, R.K. Hilliard, and J.D. McCormack provided valuable suggestions, experience and assistance in the planning and execution of this test series. Battelle Northwest Laboratory photographers documented the tests throughout the series, giving the valuable record presented in this report. Cooperative efforts between the researchers at Sandia Laboratories, HEDL's FFTF safety organization under D.E. Simpson, and the CRBRP safety organization through J. Scharnhorst provided the technical guidance, direction and impetus behind these tests. 
$\begin{array}{ll} & \text { Abstract } \\ & \text { Acknow ledgements } \\ & \text { Figures } \\ & \text { Tables } \\ \text { I. } & \text { SUMMARY } \\ \text { II. } & \text { INTRODUCTION } \\ \text { III. } & \text { EXPERIMENTAL FACILITY AND PROCEDURE } \\ & \text { A. TEST FACILITY } \\ \text { B. TEST CELL } & \text { C. SODIUM DELIVERY SYSTEM }\end{array}$

IV. TEST ARTICLES 11

A. CONCRETE SAMPLES 11

B. SODIUM RESERVOIRS 17

C. TEST ARTICLE ASSEMBLY 21

D. INSTRUMENTATION 21

V. TEST PROCEDURE 29

VI. TEST RESULTS 31

A. TEST DISCUSSION -- TEST SC-13 31

B. TEST DISCUSSION -- TEST SC-14 33

C. TEST DISCUSSION -- TEST SC-15 44

D. TEST DISCUSSION -- TEST SC-16 49

E. TEST DISCUSSION -- TEST SC-17 57

F. TEST DISCUSSION -- TEST SC-18 62 


\section{CONTENTS}

Page

G. TEST DISCUSSION -- TEST SC-19

66

H. TEST DISCUSSION -- TEST SC-20

71

I. TEST DISCUSSION -- TEST SC-21

80

J. TEST DISCUSSION -- TEST SC-22

87

VII. SUMMARY OF OBSERVED PENETRATIONS

99

VIII. RELEASE OF GASEOUS REACTION PRODUCTS 105

IX. REFERENCES

111 


\section{FIGURES}

Figure $\quad \underline{\text { Page }}$

1 Plan View of the Large Sodium Fire Facility, 105-DR Building 8

2 Schematic of Test Article 12

3 Concrete Section of Test Article Before Pouring the Concrete 13

4 Lower Section of Test Article Showing Concrete 14

5 Concrete Cask, Including Thermocouple Locations 15

6 Sketch of the Horizontal Surface Test Sodium Reservoir 22

$7 \quad$ Horizontal Test Sodium Reservoir Lid 23

8 Test Installation 24

9 SC-13 Sodium Poo 1 Temperatures 32

10 SC-13 Cell Pressure and Indicated Hydrogen Concentration 34

11 SC-13 Test Specimen $\quad 35$

12 Detail on the Surface of SC-13 Test Specimen 36

13 SC-14 System Temperatures 38

14 SC-14 Cell Pressure and Indicated Hydrogen Concentration 39

15 Surface of Test Specimen SC-14 41

16 Surface of Test Specimen SC-14 After Removal of Residue 42

17 Unreacted Concrete of Test Specimen SC-14 43

18 SC-15 System Temperatures 45

19 SC-15 Cel1 Pressure and Indicated Hydrogen Concentration 46

20 SC-15 Test Article Before Disassembly 47

21 Reaction Product Residue on Test SC-15 Concrete Sample 48

22 Surface of Unreacted Concrete from Test SC-15 50

23 SC-16 System Temperatures 51 


\section{FIGURES (Cont'd)}

Figure

$\underline{\text { Page }}$

24 SC-16 Cel1 Pressure and Indicated Hydrogen Concentration

53

25 Test Article from Test SC-16 Before Disassembly

54

26 Concrete Surface and Location of Maximum Penetration from Test SC-16

55

27 Unreacted Concrete Specimen from Test SC-16 56

28 SC-17 System Temperatures 58

29 SC-17 Cell Pressure and Indicated Hydrogen Concentration 60

30 Top Surface of Concrete Specimens After Test SC-17 61

31 Concrete Specimen from Test SC-17 After Partial Inspection 63

32 SC-18 System Temperatures $\quad 64$

33 SC-18 Cell Pressure and Indicated Hydrogen Concentration 65

34 Surface of Test Specimen SC-18 Concrete Section Following Test

35 Concrete Specimen After Removal of a Portion of Reaction Product Crust

36 Penetration Depths Following Test SC-18

69

37 SC-19 System Temperatures $\quad 70$

38 SC-19 Ce11 Pressure and Indicated Hydrogen Concentration 72

39 Surface of Test SC-19 Concrete Specimen Following Test 73

40 Concrete from Test SC-19 After Inspection 74

$41 \quad$ SC-20 System Temperatures $\quad 76$

42 SC-20 Ce11 Pressure and Indicated Hydrogen Concentration 77

43 Surface of Test Specimen SC-20 Concrete Section After Test 78

44 Side View of Test SC-20 Concrete Test Section After

Removal of Cask 


\section{FIGURES (Cont'd)}

Figure Page

45 Partial Section View of Concrete Specimen from Test SC-20 81

$46 \quad$ SC-21 System Temperatures 83

47 SC-21 Cell Pressure and Indicated Hydrogen Concentration 84

48 SC-21 Test Article After Removal of Sodium Section 85

49 Detail of the Reaction Product Mass from Test SC-21 86

50 Side View of the Test Specimen from Test SC-21

51 Detailing the Observed Penetration and Showing Substantial Cracking of the Specimen

52 SC-22 System Temperatures 90

53 SC-22 Cel1 Pressure and Indicated Hydrogen Concentration 92

54 General View of the Complete Test Assembly after Removal from the Test Vessel

55 The Surface of the Reaction Product Mass 94

56 The Bottom of the Reaction Product Mass Showing a Section of Unreacted Concrete

57 Cross Section of the Concrete Section of Test SC-22 96

58 Sodium and Sodium Hydroxide Penetration into Concrete 104

$59 \quad$ Hydrogen Released Data 109 
$\underline{T a b l e}$

1 Sumary of SC Test Conditions

2 Concrete Mix Composition 16

3 WRL Basalt Concrete Composition 18

4 Summary of Chemical Analys is of Concrete Mix B-2 18

5 WRL Limestone Concrete Composition Mix L-1 19

6 Sumary of Chemical Analys is of Concrete Mix L-1 19

7 Sumary of Test Article Ages at Test 20

8 Thermocouple List DAS and Recorder Channe1 26

9 Gas Sample System $\quad 27$

10 DAS System -- Magnetic Tape Sequence Information 28

11 Sumary of Average Penetrations 100

12 Surmary of Maximum Penetrations 101

13 Curve Fit Parameters for Penetration Depth Data 104

14 Estimate of Hydrogen Release Data 107

15 Cell Hydrogen Content 108 


\section{SUMMARY}

Chemical reactions between sodium and structural concretes are of interest for breeder reactor safety analys is because these reactions are a potential source of energy and hydrogen. Small- and intermediate-scale sodium-concrete reaction tests with magnetite and limestone concretes completed at the Hanford Engineering Development Laboratory $(1,3)$ suggested that sodium-concrete chemical reactions may be diffusion limited by the build-up of a layer of dense reaction products. However, other tests $(15,16)$ suggested that there may be different reaction mechanisms which could produce 1 arger reaction rates. One hypothes is suggested was that the accumulation of sodium hydroxide in the sodium pool may initiate and produce a more rapid chemical attack.

Intermediate scale tests with magnetite and limestone concretes have been performed previously at the Hanford Engineering Development Laboratory (HEDL) and have been reported in Reference 1. The work described herein extends that effort to basalt concretes. In addition, this effort studies the effects of sodium hydroxide accumulation on the penetration characteristics of 1 imestone and basalt concretes. Ten tests were performed, four with limestone concrete, and six with basalt concrete. The test conditions are listed in Table 1. The concrete sample surface area for each test was $0.93 \mathrm{~m}^{2}\left(1 \mathrm{ft}^{2}\right)$ and the volume was $0.028 \mathrm{~m}^{3}\left(1 \mathrm{ft}^{3}\right)$. The reaction time for each test ranged from 2 to 24 hours, and the test temperatures ranged from 510 to $870^{\circ} \mathrm{C}$ ( 950 to $1600^{\circ} \mathrm{F}$ ). Twenty-three kilograms $(50 \mathrm{lb})$ of sodium at the desired test temperature was dumped on the test article, which was at room temperature. The test article and sodium reservoir were then electrically heated to maintain the desired temperature. At the end of a specified test period, the remaining sodium (and some liquid reaction products) was decanted from the test article in an attempt to terminate the reactions.

Data were recorded in the form of temperatures in the sodium pool, concrete, test cell and structures. Continuous gas analys is for hydrogen, oxygen, and moisture were recorded. Post-test examination consisted of 
TABLE 1

SUMMARY OF SC- TEST CONDITIONS

\begin{tabular}{|c|c|c|c|c|c|}
\hline $\begin{array}{c}\text { Test } \\
\text { Number }\end{array}$ & $\begin{array}{r}\text { Tar } \\
\text { Temp } \\
\left({ }^{\circ} \mathrm{C}\right) \\
\end{array}$ & $\begin{array}{l}\text { et } \\
\text { ature } \\
(\mathrm{OF}) \\
\end{array}$ & $\begin{array}{l}\text { Target } \\
\text { Time } \\
(h r) \\
\end{array}$ & $\begin{array}{c}\text { Concrete } \\
\text { Type } \\
\end{array}$ & Comments \\
\hline 13 & 870 & 1600 & $24(1)$ & Limestone & $\begin{array}{l}427^{\circ} \mathrm{C}\left(800^{\circ} \mathrm{F}\right) \\
\mathrm{NaOH} \text { Added } 024 \mathrm{hr}\end{array}$ \\
\hline 14 & 870 & 1600 & 24 & Limestone & $\mathrm{NaOH}(2) \circ \mathrm{O} h r$ \\
\hline 15 & 870 & 1600 & 2 & Basalt & \\
\hline 16 & 870 & 1600 & 8 & Basalt & \\
\hline 17 & 870 & 1600 & 24 & Basalt & Interrupted pour (3) \\
\hline 18 & 870 & 1600 & 8 & Limestone & $\begin{array}{l}\mathrm{NaOH}+\text { concrete } \\
\text { "chunks" } 4)^{\circ} 0 \mathrm{hr}\end{array}$ \\
\hline 19 & 677 & 1250 & 8 & Limestone & $\mathrm{NaOH}(2) \propto 0 \mathrm{hr}$ \\
\hline 20 & 510 & 950 & 8 & Basalt & $\mathrm{NaOH}(2) \odot 0 \mathrm{hr}$ \\
\hline 21 & 677 & 1250 & 8 & Basalt & $\mathrm{NaOH}(2) \propto 0 \mathrm{hr}$ \\
\hline 22 & 870 & 1600 & 24 & Basalt & 2nd "24" hr test (5) \\
\hline
\end{tabular}

(1) Minimum time, extended 2 hours after addition of $\mathrm{NaOH}$.

(2) Approximately $3.6 \mathrm{~kg}(8 \mathrm{lb})$ of $\mathrm{NaOH}$ pellets placed on concrete surface prior to adding sodium.

(3) Technical difficulties halted pour after 9-11 kg (20-25 lb) $\mathrm{Na}$ transferred. Remainder transferred $5 \mathrm{hr}$ later.

(4) $3.6 \mathrm{~kg}$ ( $8 \mathrm{lb}) \mathrm{NaOH}$ as in (+) $4.5 \mathrm{~kg}$ and (10 ib) of $2.5 \mathrm{~cm}$ (1 in.) dia. chunks added prior to sodium transfer.

(5) Repeat of SC-17 with no problems on transfer. 
determinations of penetration depths, chemical analyses and visual observations. Principal test results included the following:

- The chemical reaction penetration into basalt concrete appeared to be limited by the formation of a viscous reaction product layer similar to that in the tests for magnetite and limestone concrete reported earlier(1). Assuming a diffusion limited chemical reaction, the chemical reaction penetration could be empirically described by the asymptotic expression:

$$
x=A\left(1-e^{-B t}\right)
$$

where $X$ is in $\mathrm{cm}, t$ is in seconds,

$$
\begin{aligned}
& A=7.75 \mathrm{~cm}(3.05 \mathrm{in}) \text { and } \\
& B=7.42 \times 10^{-5} \mathrm{Sec}^{-1}\left(0.27 \mathrm{hr}^{-1}\right)
\end{aligned}
$$

- The addition of sodium hydroxide, either initially or later on in the test, did not substantially alter the chemical reaction penetration into the concrete.

- At a sodium pool temperature of $510^{\circ} \mathrm{C}$ (9500F) with added sodium hydroxide, no significant reaction penetration was noted for basalt concrete. At a sodium pool temperature of $677^{\circ} \mathrm{C}\left(1250^{\circ} \mathrm{F}\right)$ with added sodium hydroxide, the reaction penetration into basalt concrete was about half that observed for sodium alone at $870^{\circ} \mathrm{C}\left(1600^{\circ} \mathrm{F}\right)$.

- Reaction penetrations into limestone concrete with added sodium hydroxide were observed to be about 25\% larger than those penetrations with sodium alone. Sodium hydroxide added to the sodium poo 124 hours into the test did not penetrate the reaction product layer. 
-

.

4

- 


\section{INTRODUCTION}

A major objective of the Fast Reactor Safety Program Plan is to demonstrate that containment integrity will be maintained throughout a variety of postulated accident scenarios, including accidents beyond the design base. Consequently, an area which is addressed for completeness is sodium-concrete reactions which can generate energy and hydrogen. The major concern is how much and how fast can hydrogen be generated, and how much energy would be produced from the reactions.

Several experimental programs $(1-17)$ have been completed in regard to sodium-concrete reactions. The tests at $\operatorname{HEDL}^{(1,3,5,11)}$ have focused on determining the energy released, the rate of reaction penetration, and the hydrogen released from sodium-concrete reactions. Two series of small-scale (up to $0.028 \mathrm{~m}^{3}$ of concrete and up to $23 \mathrm{~kg}$ of sodium) sodium-concrete reaction tests, $(1,3,11)$ have been performed at HEDL for limestone and magnetite-concretes. The major results of these tests were that the average sodium reaction penetration depth into the concrete after 24 hours was typically $5 \mathrm{~cm}$, and the bulk of the reaction penetration occurred during the first 8 hours with relatively little additional reaction penetration occurring during the remaining 16 hours. Post-test analys is of the unreacted concrete generally showed that over $80 \%$ of the moisture initially present in the concrete was released during the test. The extent of water released from the concrete resulted from heat transfer in the concrete rather than from sodium penetration of the concrete. A NaOH reaction product phase was produced at the concrete interface which generally formed a viscous barrier layer of reaction products, which 1 imited the reaction penetration into concrete to a few (up to 5) centimeters. Post-test examination of these limited penetration test articles showed that the reaction product was characterized by a hard, rock-like consistency.

Large-scale sodium-concrete reaction tests (normally $1.57 \mathrm{~m}^{3}$ of concrete and 20 to $250 \mathrm{~kg}$ of sodium) have also been performed ${ }^{(15,16)}$ using a right cylindrical concrete crucible with cylindrical cavity as the sodium 
reservoir. Chemical reaction penetrations varied from very little penetration up to $30.5 \mathrm{~cm}$ penetration, with the test generally being sodium limited for those tests where large chemical reaction penetrations occurred. These tests suggested that there may be a different reaction mechanism which could produce larger reaction rates. One hypothesis suggested was that the accumulation of sodium hydroxide in the sodium pool may initiate and produce a more rapid chemical attack.

The objective of the present investigation was to extend the previous HEDL intermediate scale sodium-concrete reaction studies to include basalt concrete, as well as to study the effects of sodium hydroxide accumulation on the chemical reactions of sodium with limestone and basalt concrete. Ten tests were performed, four with limestone, and six with basalt concrete. The concrete sample surface area for each test was $0.93 \mathrm{~m}^{2}\left(1 \mathrm{ft}^{2}\right)$ and the volume was $0.028 \mathrm{~m}^{3}\left(1 \mathrm{ft}^{3}\right)$. The reaction time for each test ranged from 2 to 24 hours, and the test temperatures ranged from 510 to $870^{\circ} \mathrm{C}$ (950 to $\left.1600^{\circ} \mathrm{F}\right)$. 


\section{EXPERIMENTAL FACILITY AND PROCEDURE}

\section{A. TEST FACILITY}

All tests were performed in the Small Fire Room of the Large Sodium Fire Facility (LSFF), shown in Figure 1. This facility provides four large concrete cells, two of which are currently used for sodium spill and fire studies. The facility has provisions for storing, melting, and transferring large amounts of sodium at temperatures of up to $650^{\circ} \mathrm{C}\left(1200^{\circ} \mathrm{F}\right)$ and up to $23 \mathrm{~kg}(50 \mathrm{lb})$ at temperatures to $871^{\circ} \mathrm{C}\left(1600^{\circ} \mathrm{F}\right)$. A ventilation system exists which is capable of exhausting up to $4.7 \mathrm{~m}^{3} / \mathrm{sec}(10,000 \mathrm{scfm})$ of air at $120^{\circ} \mathrm{C}\left(250^{\circ} \mathrm{F}\right)$ to a $61-\mathrm{m}(200-\mathrm{ft})$ stack. The ventilation system includes a scrubber, a HEPA filter bank, and an orifice flowmeter.

A liquid nitrogen supply system is included in the facility. This system is capable of providing up to $.09 \mathrm{~m}^{3} / \mathrm{sec}(200 \mathrm{scfm})$ of nitrogen up to a total volume to $1400 \mathrm{~m}^{3}(50,000 \mathrm{scf})$. Flowrates are measured using a turbine flowmeter or rotameter, depending on flowrate.

The facility also provides general work and storage areas, office space, and cleanup facilities.

\section{B. TEST CELL}

The tests were performed in the small fires test cell, located in the Small Fire Room. This cell is approximately $3.7 \mathrm{~m}(12 \mathrm{ft})$ tall by $2.1 \mathrm{~m}$ $(7 \mathrm{ft})$ in diameter with a total volume of approximately $14 \mathrm{~m}^{3}\left(500 \mathrm{ft}^{3}\right)$. A $1.2-m(4-f t)$ personnel equipment hatch is provided, along with a large number of $f l$ anged and threaded pipe penetrations.

Purge and vent are accomplished with the LSFF nitrogen supply system. Two vents are provided. One, at the $3.7-\mathrm{m}(12-\mathrm{ft})$ level, is sealed by a 1.9-cm (3/4-in.) electrically operated diaphragm valve. This valve fails closed on loss of electrical power. At the $1.2-\mathrm{m}(4-\mathrm{ft})$ level, a $5-\mathrm{cm}$ 


\section{LARGE SODIUM FIRE FACILITY}

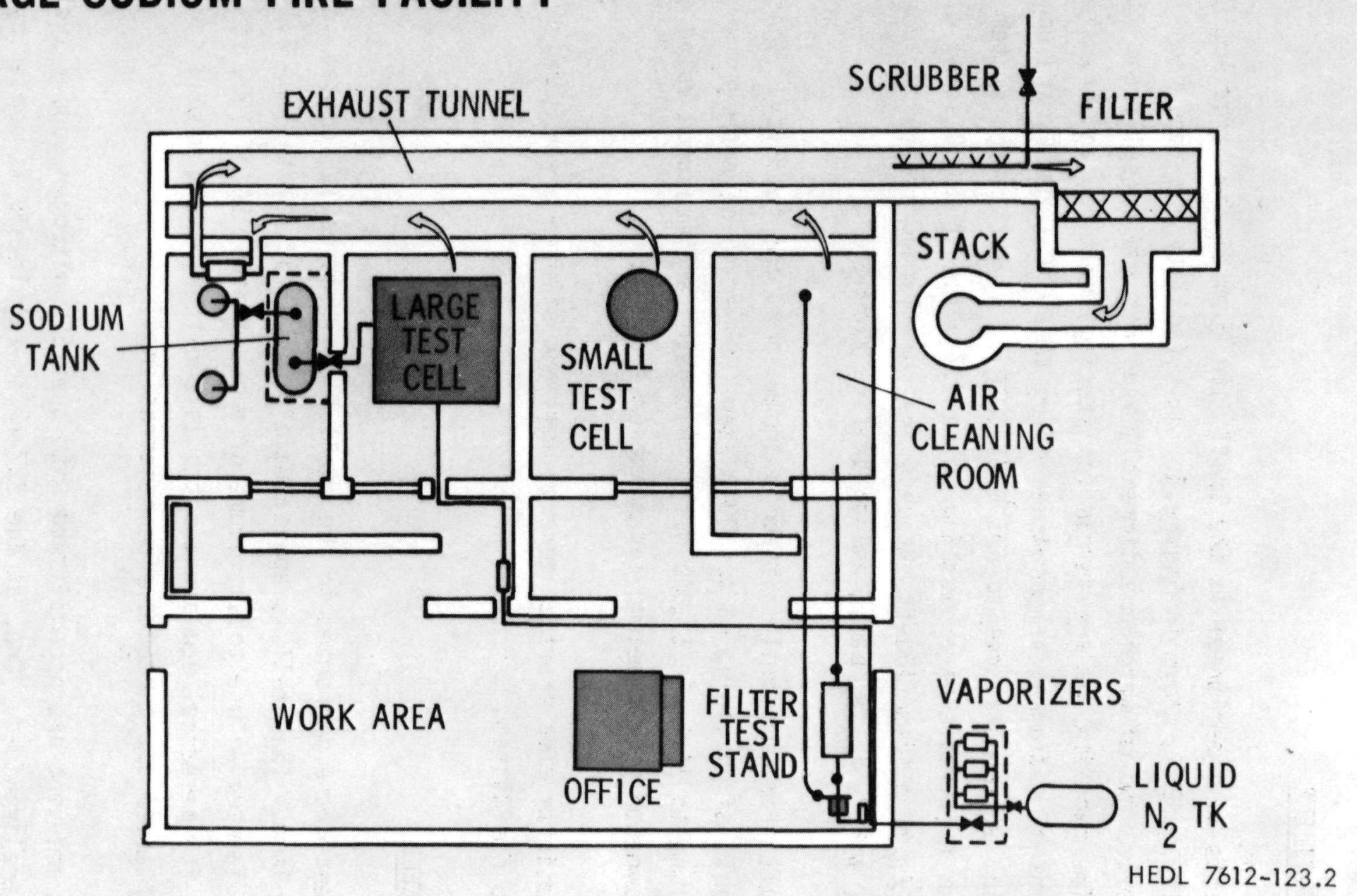

FIGURE 1. Plan View of the Large Sodium Fire Facility, 105-DR Building. (P7612073-1) 
(2-in.) line, sealed with a 5-cm (2-in.) ball valve, is included. This valve is pneumatically operated, electrically actuated, and fails open on loss of electric power. The air supply to this valve is a high pressure nitrogen bottle. Consumption rate is low enough to ensure adequate supply in any event, including extended periods of unmanned operation.

Chain falls are provided both inside and outside the test cell for handling the heavy assembled test articles. Water and drain lines are available for cleanup as necessary.

\section{SODIUM DELIVERY SYSTEM}

Sodium was supplied to the test article, at the desired test temperature, from the Portable Sodium Transfer Vessel (PSTV). This vessel is capable of providing up to $23 \mathrm{~kg}(50 \mathrm{lb})$ of sodium at temperatures up to $871^{\circ} \mathrm{C}\left(1600^{\circ} \mathrm{F}\right)$. The vessel atmosphere is argon, and an external argon bottled gas supply provides the necessary pressurized argon used for cover gas and for sodium transfer. Sodium is charged into the PSTV at $2040^{\circ} \mathrm{C}$ $\left(400^{\circ} \mathrm{F}\right)$ from a portable drum melt station. 
10 


\section{TEST ARTICLES}

Test articles were made up from two assemblies. The lower section consisted of a mild steel cask into which $0.028 \mathrm{~m}^{3}\left(1 \mathrm{ft}^{3}\right)$ of concrete was cast. The upper section, also a mild steel cask, served as the sodium reservoir. The two sections were attached by seal-welding two flanges provided. (See Figure 2.)

Each test article was equipped with thermocouples and electrical heaters. All assemblies were insulated with $7.6 \mathrm{~cm}$ ( 3 in.) of mineral wool insulation prior to installation into the test rig. Figures 3 and 4 are photographs of the concrete section before and after pouring the concrete.

\section{A. CONCRETE SAMPLES}

The concrete samples were prepared by pouring $0.028 \mathrm{~m}^{3}\left(1 \mathrm{ft}^{3}\right)$ of concrete into a cask made of mild steel. The cask was nominally $34 \mathrm{~cm}$ (13.5 in.) inside diameter and $30.5 \mathrm{~cm}$ (12 in.) deep. Flanges were welded to both ends. At one end, a blank plate with a fiber gasket was bolted to provide the base. The other flange allowed the sodium reservoir to be sealwelded to the concrete specimen. Four Type $K$, ungrounded, stainless steel sheathed, $1.6-\mathrm{mm}(1 / 16-$ in. $)$ thermocouples were located in the cask prior to pouring the concrete. These thermocouples penetrated the sides of the casks through swagelock fittings and extended diameterally approximately $10 \mathrm{~cm}$ (4 in.) from the wall. The thermocouples were located approximately $( \pm 6 \mathrm{~mm}$, $1 / 4$ in.) at locations $-2.5,-7.6,-17.8$, and $-27.9 \mathrm{~cm}(-1,-3,-7$, and -11 in.) below the level of the concrete surface. Figure 3 shows a sketch of the concrete cask prior to filling with concrete.

Two concrete mixes, basalt and 1 imestone, were prepared for these tests, both chosen for their general availability and potential use in reactor applications. The mix composition was the same for the two concretes, with the only difference being the type of aggregate. Table 2 summarizes the composition used. 


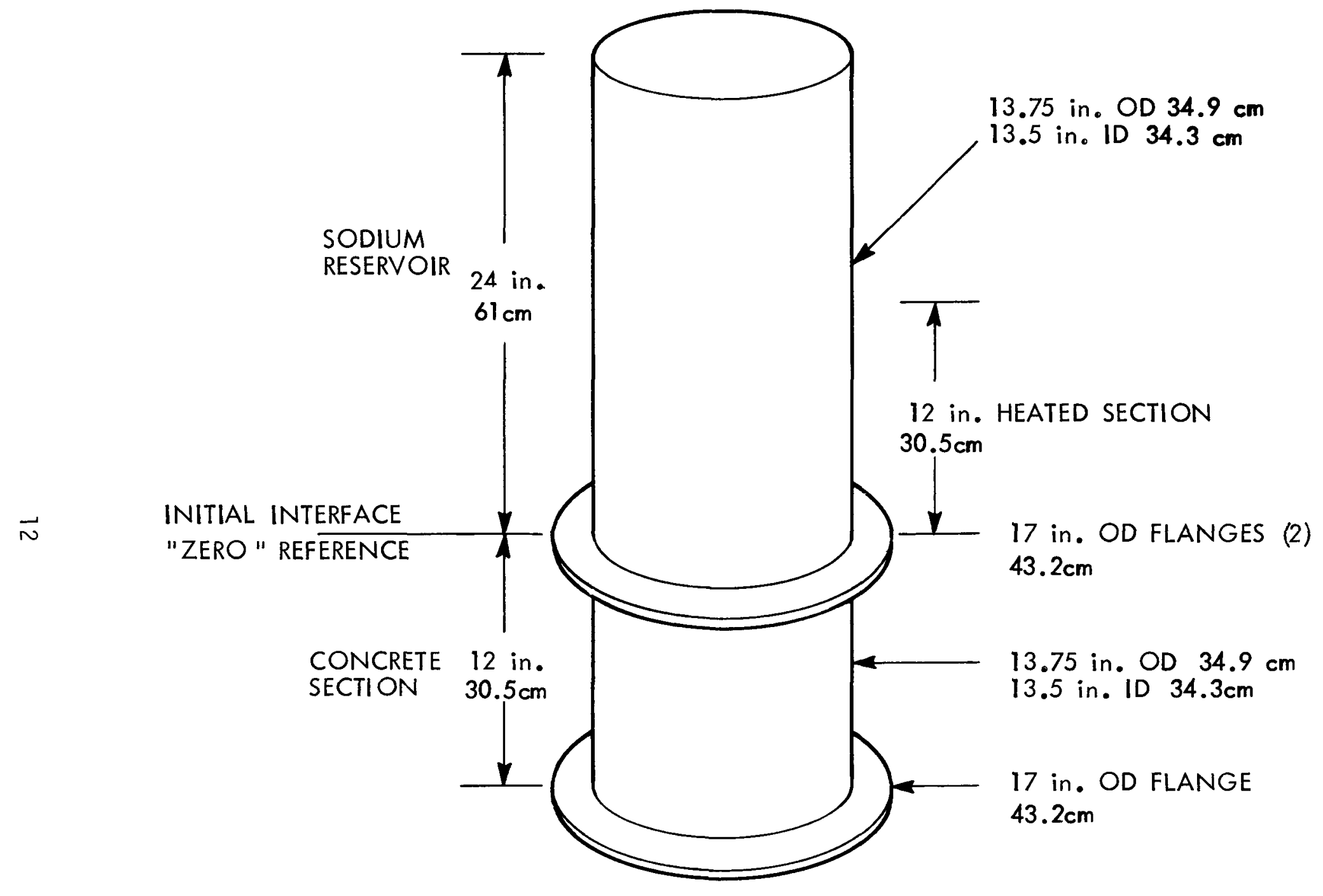

HEDL $7908-173.2$

FIGURE 2. Schematic of Test Article. 

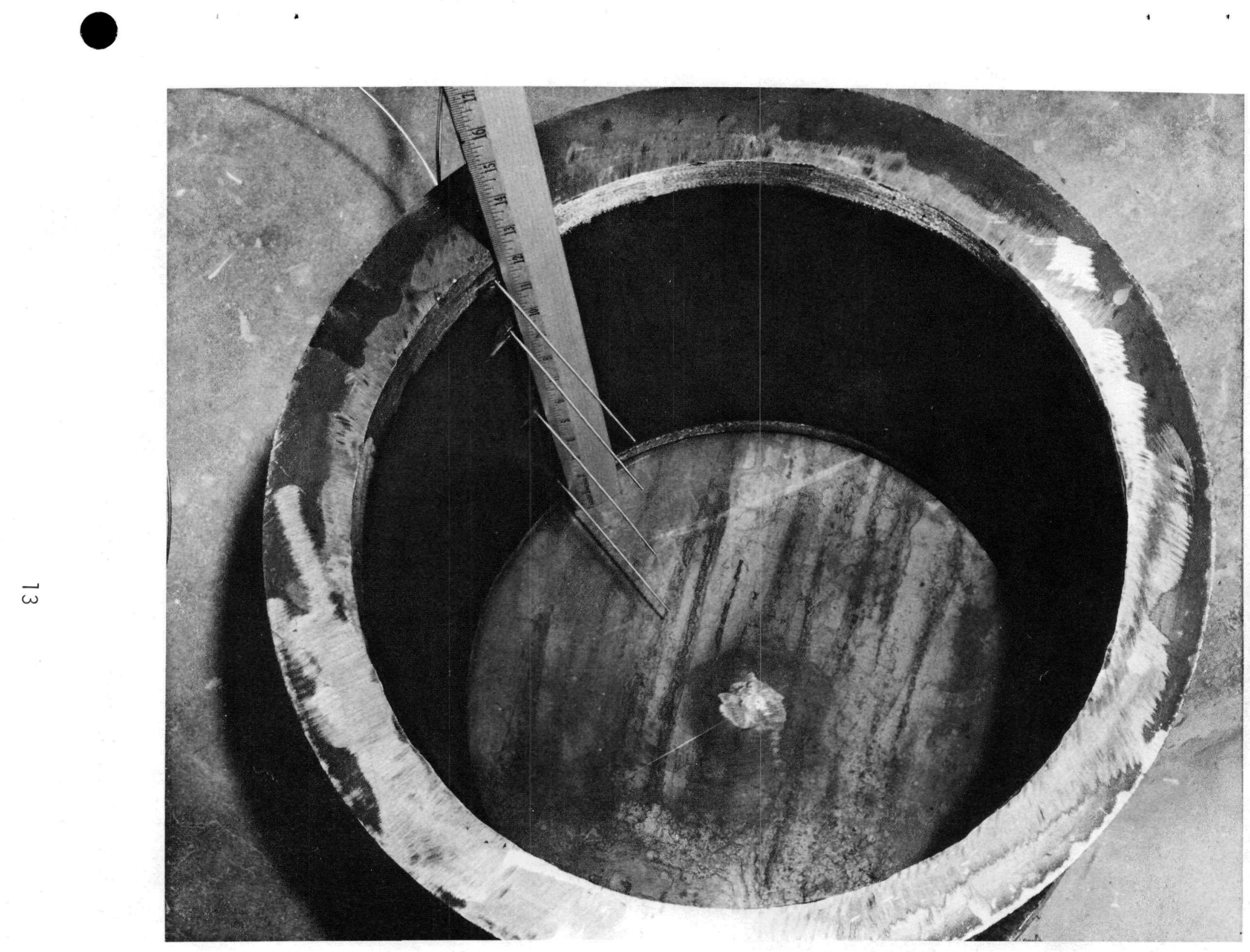

FIGURE 3. Concrete Section of Test Article Before Pouring the Concrete.

Neg $765445-1$ 


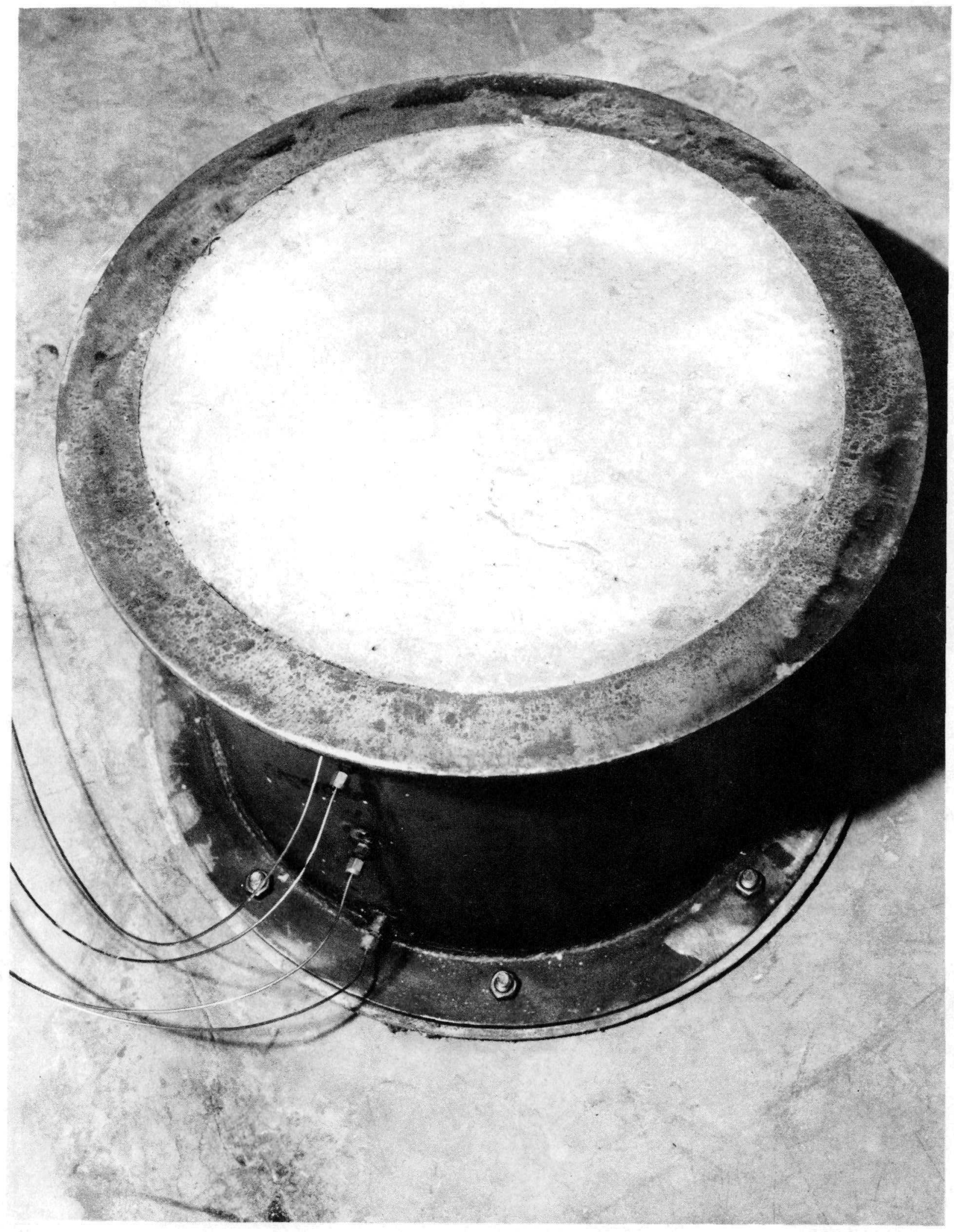

FIGURE 4. Lower Test Section with Concrete.

Neg 765445-2 


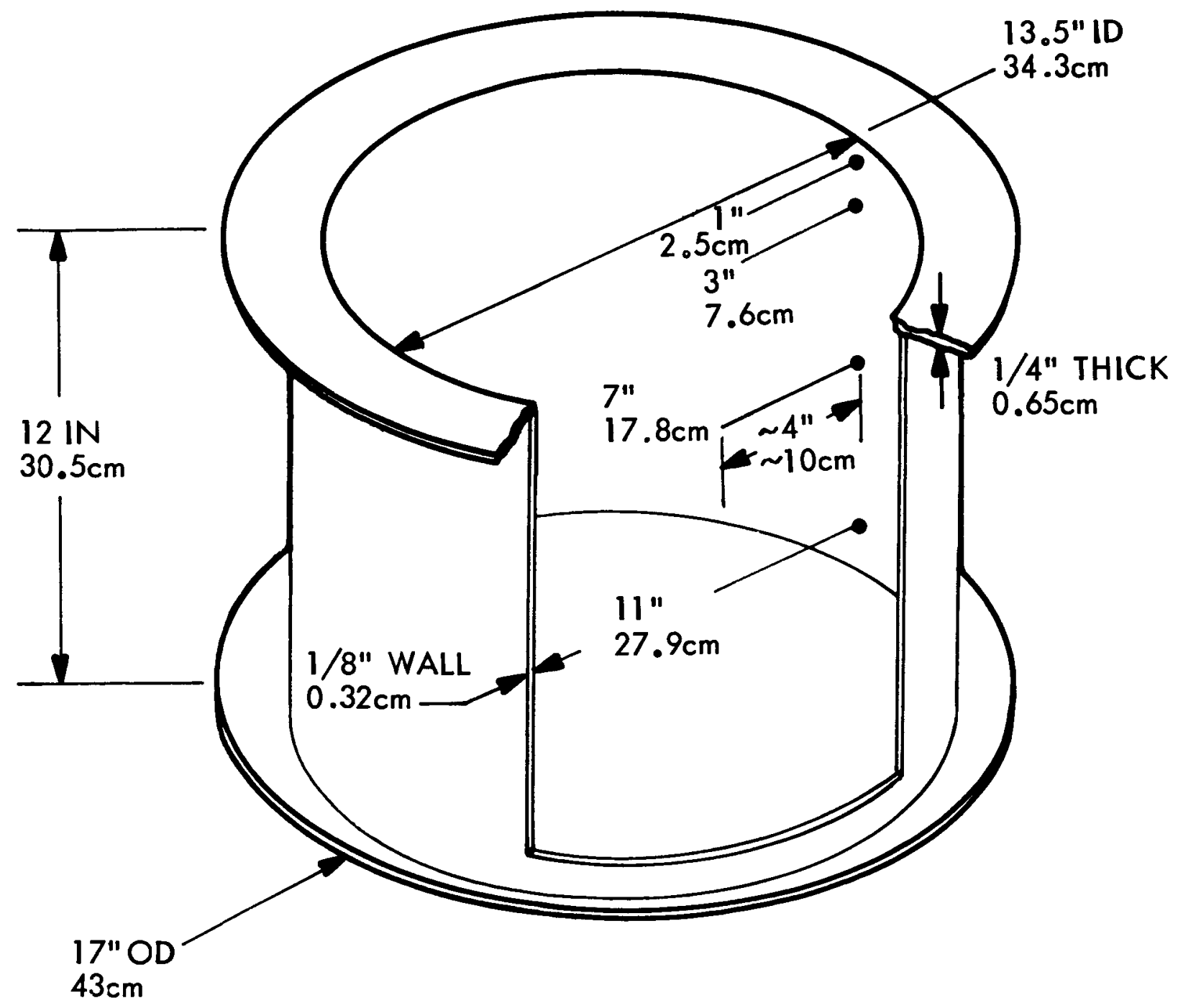

FIGURE 5. Concrete Cask, Including Thermocouple Locations. (P774747-3) 
TABLE 2

CONCRETE MIX COMPOSITION

Component

$\frac{\text { Content }}{\mathrm{kg} / \mathrm{m}^{3} \quad \mathrm{lb} / \mathrm{yd}^{3}}$

Cement (a)

Pozzalan

Sand \#4 (b)

Aggregate (3/4 in.)(b)

Water

Entrained Air
260

46

439

78

839

1080

142

$5 \%$
Weight $(\%)$

11.0

2.0

35.4

45.6

6.0

$5 \%$
1415

1821

240

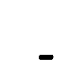


The specimens were prepared by pouring the concrete into the prepared casks. A sheet metal shroud was used to protect the thermocouples and to maintain their alignment during the pouring. Specimens were tamped and troweled. No attempt was made to produce a smooth finish, but rather all aggregate was submerged and the surfaces smoothed with a wood float.

Laboratory analyses of a sample of magnetite, basalt, and limestone concrete were performed by the Westinghouse Research Laboratories. (12) Table 3 details the cement used and Table 4 summarizes the result of this analysis for basalt concrete. The limestone mix used for the laboratory analyses was somewhat different than the composition used for the present tests. Tables 5 and 6 sumarize the mix and results of the analysis for 1 imestone concrete.

Basalt concrete samples were poured on May 6, 1976. The test articles were cured in a damp environment for 28 days, after which they were stored indoors until they were assembled into a test article.

Limestone samples were poured on two separate dates. Samples for tests SC-13 and 14 were poured on May 5, 1977, and had a 28-day compressive strength of $4240 \mathrm{psi}$. The remaining samples were poured on January 11, 1978.

Table 7 sumarizes the ages of the specimen at the time of each test.

\section{B. SODIUM RESERVOIRS}

The sodium reservoir used for these tests was an open right-circular cylinder, flanged to mate with the concrete pots. The cylinder was $34 \mathrm{~cm}$ (13.5 in.) ID and $61 \mathrm{~cm}(24$ in.) high.

A lid with a standpipe was fitted loosely to the top of the reservoir. Two or three thermocouples (depending on the test) were fixed to the inside to measure the sodium temperatures, one at $2.5 \mathrm{~cm}(1 \mathrm{in.})$ and one at $12.7 \mathrm{~cm}$ ( 5 in.) from the concrete surface after assembly. Later tests used a third 
TABLE 3

WRL BASALT CONCRETE COMPOSITION MIX B-2

$\begin{array}{lcr}\text { Cement (a) } & 494 \mathrm{lb} / \mathrm{yd}^{3} & 293 \mathrm{~kg} / \mathrm{m}^{3} \\ \text { Sand } & 1471 \mathrm{lb} / \mathrm{yd}^{3} & 872 \mathrm{~kg} / \mathrm{m}^{3} \\ \text { Aggregate } & 1804 \mathrm{lb} / \mathrm{y}^{3} & 1070 \mathrm{~kg} / \mathrm{m}^{3} \\ \text { Water } & 246 \mathrm{lb} / \mathrm{y}^{3} & 146 \mathrm{~kg} / \mathrm{m}^{3} \\ \text { WRA (b) } & 25 \mathrm{oz} / \mathrm{yd}^{3} & .71 \mathrm{~kg} / \mathrm{m}^{3} \\ \text { AEA (c) } & 5 \mathrm{oz} / \mathrm{yd}^{3} & .15 \mathrm{~kg} / \mathrm{m}^{3}\end{array}$
(a) Portland Type II
(b) Water-Reducing Agent
(c) Air-Entraining Agent

TABLE 4

SUMMARY OF CHEMICAL

ANALYSIS OF CONCRETE MIX B-2

Species

$$
\begin{aligned}
& \mathrm{SiO}_{2} \\
& \mathrm{Al}_{2} \mathrm{O}_{3} \\
& \mathrm{CaO}
\end{aligned}
$$

$\mathrm{MgO}$

$\mathrm{Fe} 0$

$\mathrm{Fe}_{2} \mathrm{O}_{3}$

$\mathrm{TiO}_{2}$

$\mathrm{Na}_{2} \mathrm{O}$

$\mathrm{K}_{2} \mathrm{O}$

$\mathrm{S}=$

$\mathrm{SO}_{4}$

$\mathrm{CO}_{2}$
Weight \%

51.4

11.3

12.9

3.0

2.1

5.3

1.7

2.4

1.43

0.02

0.20

0.57

92.32 
TABLE 5

WRL LIMESTONE CONCRETE COMPOSITION

MIX L1
Cement (a)
Flyash
Limestone Sand
Limestone Aggregate
Water
AEA (b)
WRA (c)
(a) Portland Cement Type I
(b) Air Entraining Agent
(c) Water Reducing Agent

$3201 \mathrm{~b} / y \mathrm{~d}^{3}$

$230 \mathrm{lb} / \mathrm{yd}^{3}$

$190 \mathrm{~kg} / \mathrm{m}^{3}$

$1487 \mathrm{lb} / \mathrm{yd}^{3}$

$136 \mathrm{~kg} / \mathrm{m}^{3}$

$1528 \mathrm{lb} / \mathrm{yd}^{3}$

$881 \mathrm{~kg} / \mathrm{m}^{3}$

$260 \mathrm{lb} / \mathrm{yd}^{3}$

$905 \mathrm{~kg} / \mathrm{m}^{3}$

$$
15 \mathrm{oz} / \mathrm{yd}^{3}
$$

$154 \mathrm{~kg} / \mathrm{m}^{3}$

$.43 \mathrm{~kg} / \mathrm{m}^{3}$

$13.1 \mathrm{oz} / \mathrm{yd}^{3}$

$.37 \mathrm{~kg} / \mathrm{m}^{3}$

TABLE 6

SUMMARY OF CHEMICAL ANALYSIS OF CONCRETE MIX L-1

Species

$\mathrm{SiO}_{2}$

$\mathrm{Al}_{2} \mathrm{O}_{3}$

$\mathrm{CaO}$

$\mathrm{MgO}$

$\mathrm{Fe} 0$

$\mathrm{Fe}_{2} \mathrm{O}_{3}$

$\mathrm{TiO}_{2}$

$\mathrm{Na}_{2} \mathrm{O}$

$\mathrm{K}_{2} \mathrm{O}$

$\mathrm{S}=$

$\mathrm{SO}_{4}$

$\mathrm{CO}_{2}$
Weight \%

7.4

2.4

43.85

4.8

0.45

1.6

0.16

0.09

0.75

0.09

0.74

32.5

94.83 
TABLE 7

SUMMARY OF TEST ARTICLE AGES AT TEST

\begin{tabular}{|c|c|c|c|c|}
\hline $\begin{array}{c}\text { Test } \\
\text { Number } \\
\end{array}$ & $\begin{array}{c}\text { Concrete } \\
\text { Type } \\
\end{array}$ & $\begin{array}{l}\text { Date } \\
\text { Pour } \\
\end{array}$ & $\begin{array}{l}\text { Test } \\
\text { Date } \\
\end{array}$ & $\begin{array}{r}\text { Concrete } \\
\text { Age/Days } \\
\end{array}$ \\
\hline SC-13 & Limestone & $5-5-77$ & $12-14-77$ & 223 \\
\hline$S C-14$ & Limestone & $5-5-77$ & $1-10-78$ & 250 \\
\hline SC-15 & Basalt & $5-6-76$ & $2-22-78$ & 658 \\
\hline$S C-16$ & Basalt & $5-6-76$ & $2-28-78$ & 664 \\
\hline SC -17 & Basalt & $5-6-76$ & $3-16-78$ & 680 \\
\hline SC-18 & Limestone & $1-11-78$ & $3-22-78$ & 70 \\
\hline SC-19 & Limestone & $1-11-78$ & $3-28-78$ & 76 \\
\hline$S C-20$ & Basalt & $5-6-76$ & $4-5-78$ & 700 \\
\hline$S C-21$ & Basalt & $5-6-76$ & $4-12-78$ & 707 \\
\hline$S C-22$ & Basalt & $5-6-76$ & $4-17-78$ & 712 \\
\hline
\end{tabular}


thermocouple at a $7.6-\mathrm{cm}(3-i n$.$) elevation. They were located diameterally$ about $7.5 \mathrm{~cm}$ ( 3 in.) from the wall. Eight electrical resistance heaters were attached to the lower $30.5 \mathrm{~cm}$ (12 in.) of the sodium reservoir to maintain desired sodium temperatures. The heaters were arranged in four zones, each zone nominally 2400 watts. Each zone was controlled by SCR-type controllers and each zone was supplied with a thermocouple located $0.6 \mathrm{~cm}(1 / 4 \mathrm{in}$.$) from$ the heater sheath. The heaters were foil wrapped after installation to reduce radiative heat losses. Figure 6 summarizes the configuration and features of the horizontal sodium reservoir. Figure 7 shows the lid used.

\section{TEST ARTICLE ASSEMBLY}

The test article was assembled by seal-welding the sodium reservoir to the concrete specimen. The horizontal specimens were oriented at random. The welding was done with a TIG welder, and the heat-affected zone was maintained adequately far from the concrete.

Following welding and final heater and thermocouple installation, the test articles were insulated with three $2.5-\mathrm{cm}(1-\mathrm{in}$.$) layers of mineral wool$ insulation.

The test article was then bolted into a cask equipped to be rotated on the appropriate stand. The entire assembly was placed inside the test cell, along with the catch pan and support stand. Figure 8 is a photograph of the installed test specimen. The tipping mechanisms were designed to allow the test article to be decanted remotely, using a cable arrangement. The cables can be seen in Figure 4 .

\section{INSTRUMENTATION}

Test instrumentation consisted of thermocouples, gas composition analyzers, and cell pressure gauges or transducers. The locations of the test article thermocouples were discussed in the previous section. Other 


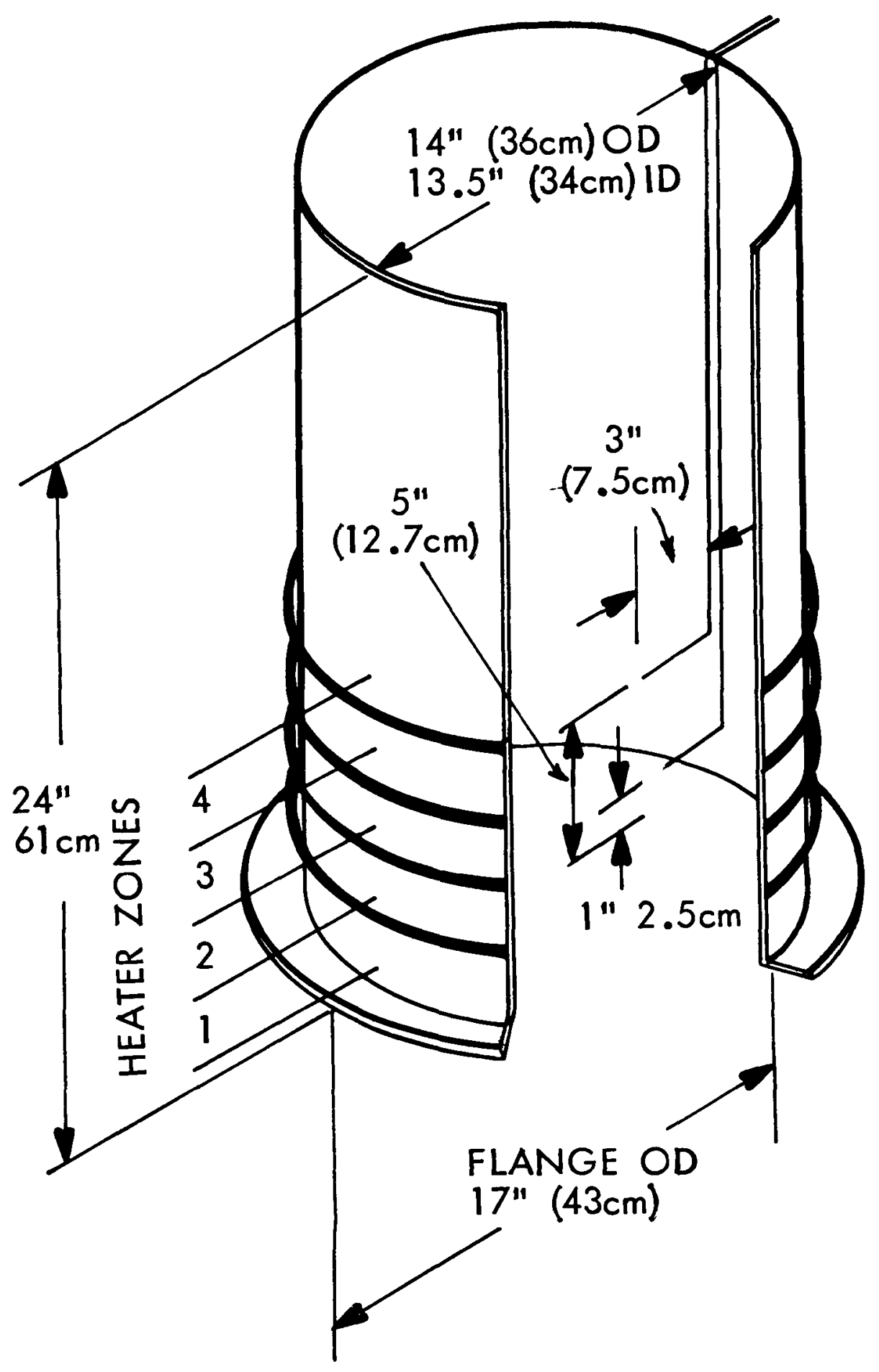

FIGURE 6. Showing a Sketch of the Horizontal Surface Test Sodium Reservoir. (P775086-1) 


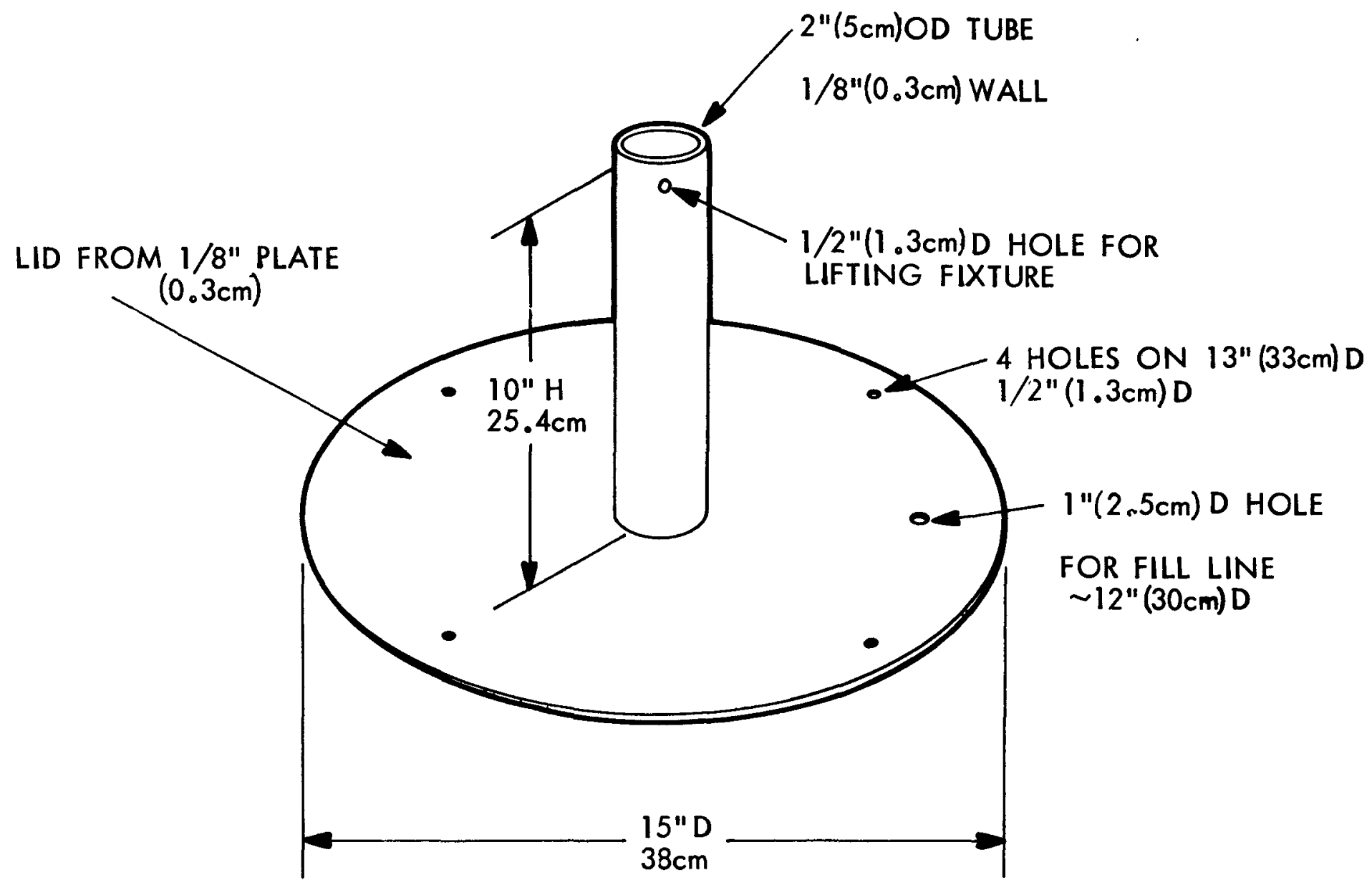

FIGURE 7. Horizontal Test Sodium Reservoir Lid. (P774747-2) 


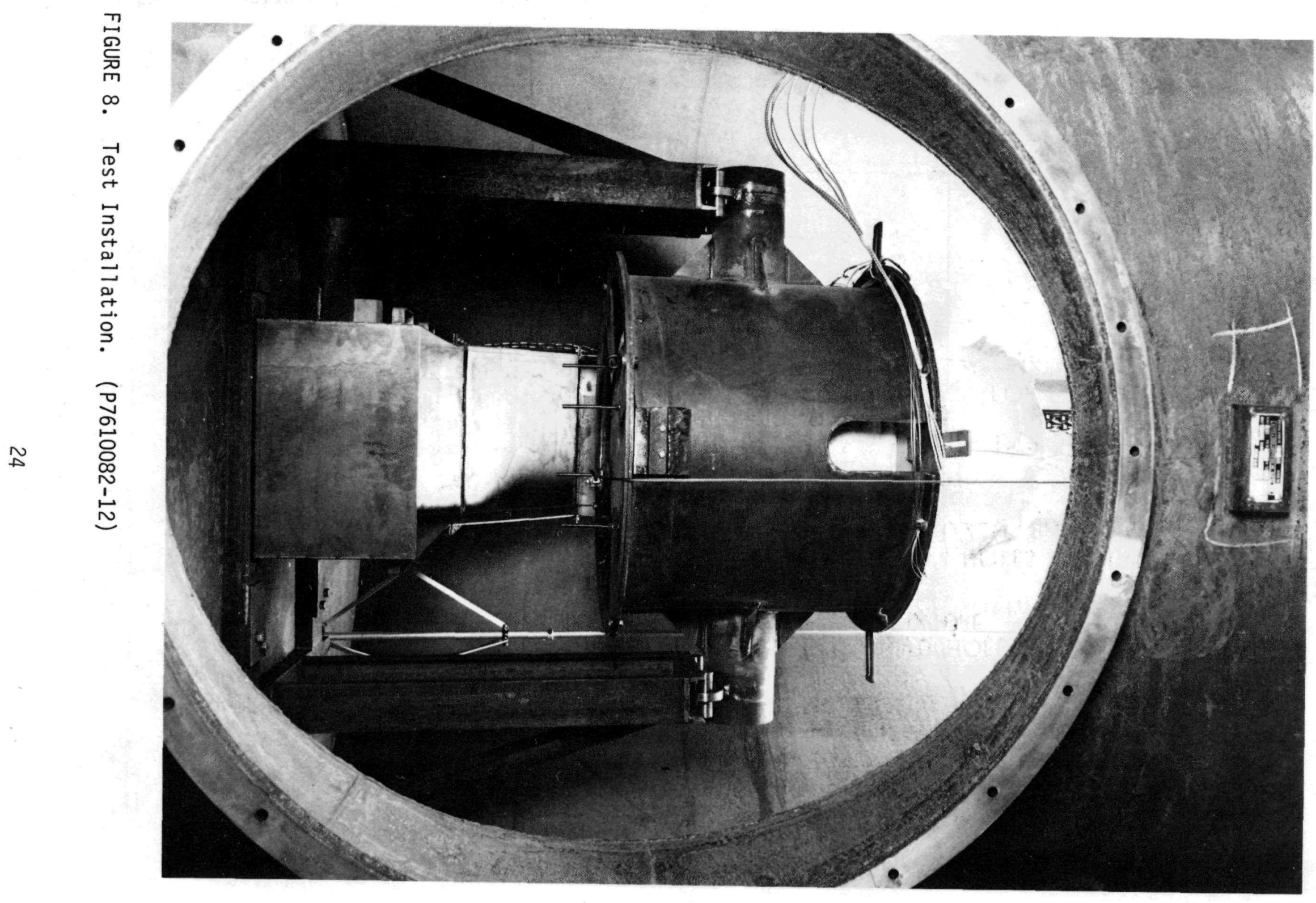

0

- 
thermocouple locations will be discussed here, along with the atmosphere monitoring devices.

In addition to the four concrete test article thermocouples, sodium reservoir thermocouples, and reservoir heater control thermocouples, 10 thermocouples were used to measure various temperatures of interest. One thermocouple was placed $5 \mathrm{~cm}$ ( 2 in.) inside the vent stack, and two were used to measure the cell atmosphere temperature -- one at the $1.8-\mathrm{m}(6-\mathrm{ft})$ and one at the 3.7-m (12-ft) levels.

One thermocouple was placed on the inside cell wall and one on the outside cell wall. Two thermocouples were used to monitor exhaust temperatures at the exit of the upper cell vent/purge line. One was placed $5 \mathrm{~cm}$ (2 in.) upstream of the exit and one was placed $5 \mathrm{~cm}$ (2 in.) downstream of the exit. One thermocouple was embedded in the test article insulation and two were installed in the dump pan. Several were also placed on the sodium dump lines. Table 8 summarizes the thermocouple locations and the associated readout channel. Thermocouple outputs were recorded on multi-point recorders, in parallel with a data logger recording on digital magnetic tape.

Continuous gas analys is was recorded from the 3.7-m (12-ft) level via the $0.6-\mathrm{cm}(1 / 4-i n$.$) line. The lines were fitted with filters upstream of$ a diaphragm-type sample pump. The cell atmosphere was sampled for hydrogen using a thermal conductivity cell; the oxygen sampler used a polarographic sensor. Water vapor was measured as dewpoint, using an aluminum oxide hygroscopic capacitor. Cell pressure was measured with a diaphragm pressure transducer. Cell pressure and gas concentrations were recorded on multipoint-strip chart recorders and magnetic tape. Table 9 summarizes the gas analyzers and data acquisition. Table 10 summarizes the tape sequence number for the various recorded channels for each test. Data was recorded on tape as a continuous string of 7-digit numbers. The sequence number indicates the location in that string of the desired information. The starting point of a given Channel is $1+7 * S$ where $S$ is the sequence number associated with the channel as indicated on Table 10. 
TABLE 8

THERMOCOUPLE LIST

DAS AND RECORDER CHANNEL

Location

\begin{tabular}{|c|c|c|c|c|}
\hline & SC-13 & SC-14 & $\begin{array}{l}S C-15 \text { to } \\
S C-22\end{array}$ & $S C-16$ \\
\hline $\begin{array}{lr}\text { Sodium Reseroir } & 2.5 \mathrm{~cm}(1 \mathrm{in.}) \\
7.6 \mathrm{~cm}(3 \mathrm{in.}) & 12.7 \mathrm{~cm}(5 \mathrm{in.}) \\
& 2.5 \mathrm{~cm}(1 \mathrm{in.}) \\
& 7.6 \mathrm{~cm}(3 \mathrm{in.}) \\
& 17.8 \mathrm{~cm}(7 \text { in.) } \\
& 27.9 \mathrm{~cm}(11 \text { in.) }\end{array}$ & $\begin{array}{l}1 \\
- \\
2 \\
3 \\
4 \\
5 \\
6\end{array}$ & $\begin{array}{l}1 \\
2 \\
3 \\
4 \\
5 \\
6 \\
7\end{array}$ & $\begin{array}{l}1 \\
2 \\
3 \\
4 \\
5 \\
6 \\
7\end{array}$ & $\begin{array}{l}1 \\
2 \\
3 \\
7 \\
6 \\
5 \\
4\end{array}$ \\
\hline Vent Stack & 13 & 8 & 8 & 8 \\
\hline $\begin{array}{lll}\text { Cell } & 1.8 \mathrm{~m}(6 \mathrm{ft}) \text { Atmo. } \\
\text { Cel1 } & 3.7 \mathrm{~m}(12 \mathrm{ft}) \text { Atmo. }\end{array}$ & $\begin{array}{r}18 \\
9\end{array}$ & $\begin{array}{r}9 \\
10\end{array}$ & $\begin{array}{r}9 \\
10\end{array}$ & $\begin{array}{r}9 \\
10\end{array}$ \\
\hline Insulation & 14 & 11 & 11 & 11 \\
\hline $\begin{array}{l}\text { Cell Inside Surface } \\
\text { Cell Outside Surface }\end{array}$ & $\begin{array}{l}19 \\
10\end{array}$ & $\begin{array}{l}12 \\
13\end{array}$ & $\begin{array}{l}12 \\
13\end{array}$ & $\begin{array}{l}12 \\
13\end{array}$ \\
\hline $\begin{array}{l}\text { Catch Pan Bottom } \\
\text { Catch Pan Side }\end{array}$ & $\begin{array}{l}7 \\
8\end{array}$ & $\begin{array}{l}14 \\
15\end{array}$ & $\begin{array}{l}14 \\
15\end{array}$ & $\begin{array}{l}14 \\
15\end{array}$ \\
\hline $\begin{array}{l}1.9 \mathrm{~cm}(3 / 4 \text { in. }) \text { Vent Inside } \\
1.9 \mathrm{~cm}(3 / 4 \text { in.) Vent Outside }\end{array}$ & $\begin{array}{l}11 \\
12\end{array}$ & $\begin{array}{l}16 \\
17\end{array}$ & $\begin{array}{l}16 \\
17\end{array}$ & $\begin{array}{l}16 \\
17\end{array}$ \\
\hline Heater Zone $\begin{array}{r}1 \\
2 \\
3 \\
4\end{array}$ & $\begin{array}{l}- \\
- \\
-\end{array}$ & $\begin{array}{l}- \\
-\end{array}$ & $\begin{array}{l}18 \\
19 \\
20 \\
21\end{array}$ & $\begin{array}{l}18 \\
19 \\
20 \\
21\end{array}$ \\
\hline $\begin{array}{l}\text { Inside Dumpline } \\
\text { Outside Dumpline }\end{array}$ & - & $\overline{-}$ & $\begin{array}{l}22 \\
23\end{array}$ & $\begin{array}{l}22 \\
23\end{array}$ \\
\hline $\begin{array}{l}\mathrm{NaOH} \text { Tank Upper } \\
\text { Middle } \\
\text { Lower } \\
\text { NaOH Dump Line }\end{array}$ & $\begin{array}{l}15 \\
16 \\
17 \\
20\end{array}$ & & & \\
\hline
\end{tabular}

Tests

8 
TABLE 9

GAS SAMPLE SYSTEM

$\begin{array}{lccc}\text { Gas } & \text { Detector } & \text { DAS Point } & \text { Recorder pt. } \\ \mathrm{H}_{2} & \text { Conductivity } & 83 & 1 \\ \mathrm{O}_{2} & \text { Polarographic } & 82 & 0 \\ \mathrm{H}_{2} \mathrm{O} & \begin{array}{l}\text { Hygroscope } \\ \text { Capacitor }\end{array} & 85^{*} & 4 \\ \text { Pressure } & & 86 & 5\end{array}$

* Not recorded for Test SC-14 due to malfunction. 
ณ

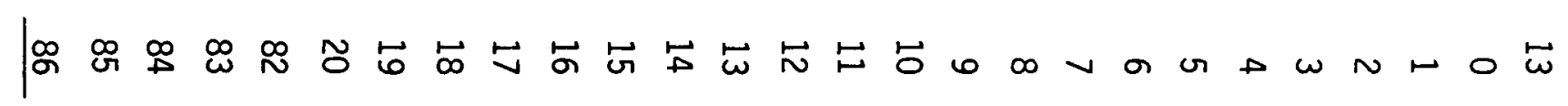

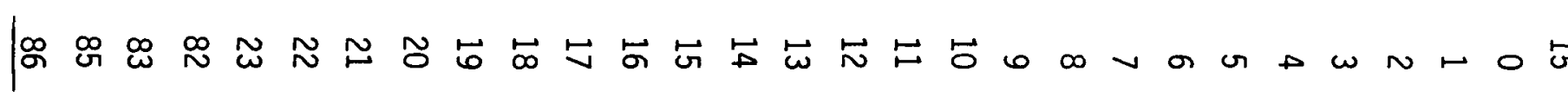

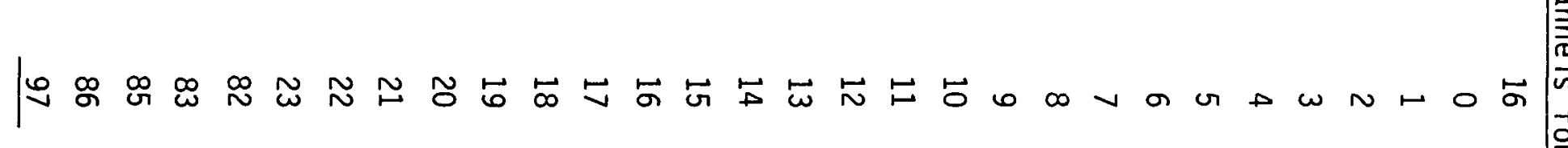

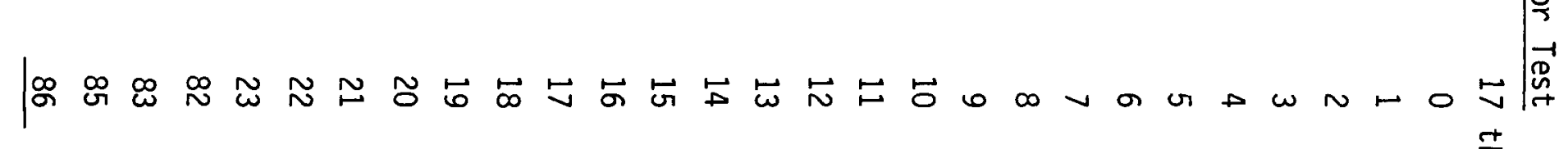




\section{TEST PROCEDURE}

Following installation of the test article into the test cell, testing began by purging the test cell with nitrogen until the cell atmosphere contained less than $1 \%$ of $\mathrm{O}_{2}$ by volume. About five minutes prior to sodium dump, the sodium supply lines were preheated to $650^{\circ} \mathrm{C}\left(1200^{\circ} \mathrm{F}\right)$ and the sodium reservoir heater zones 2, 3 and 4 were energized with the controller set points set to the desired test temperature. One minute prior to sodium spill, heater zone 1 was energized. At time zero, the sodium supply valve from the PSTV was opened. Sodium transfer was determined to be complete when the argon cover gas flowrate to the PSTV increased substantially. The PSTV was removed after cooling and reweighed to verify the quantity of sodium transferred.

Following the pour, the heater controllers were allowed to maintain the desired test temperature. No effort was made to monitor power consumption. Gas analysis and thermocouple data were monitored and recorded during the test.

One half hour prior to the decant, the $1.9-\mathrm{cm}(3 / 4-\mathrm{in}$.$) vent valve was$ opened. Approximately 15 minutes thereafter, the $5.1-\mathrm{cm}(2-i n$.$) valve was$ opened and a $5.6-\mathrm{m}^{3} / \mathrm{min}(200-\mathrm{cfm})$ nitrogen purge was initiated. Two minutes prior to the decant, the purge was reduced to $0.14 \mathrm{~m}^{3} / \mathrm{min}$ ( $5 \mathrm{cfm}$ ) and the tipping cables attached to the lid and dump lines. At the desired decant time ( $T$ zero + test time), the decant line was pulled to tip the reaction vessel. Following the decant, the reaction vessel was allowed to turn upright, the cables were removed, and the cable penetrations were resealed. The low flow $\left(0.14 \mathrm{~m}^{3} / \mathrm{min}, 5 \mathrm{cfm}\right)$ nitrogen purge was maintained during cooldown.

Following cooldown, the cell was ventilated with air and entered. Disassembly, inspection, and cleanup began irmediately. Samples were taken of the catch pan contents and any unusual features were noted. 
The test article was removed, insulation was removed, and the sodium reservoir was separated from the concrete specimen by grinding off the seal weld. Samples were taken of the reaction product. The concrete was removed from the cask either by grinding or flame cutting the cask to separate it into two halves. Photographs were taken of the concrete. The sections were photographed and the profile of the reaction-concrete interface was determined.

Some exceptions to this general procedure occurred. These exceptions are covered under the general discussion of each test. 


\section{TEST RESULTS}

Results of the tests described here fall into several categories. Of principal importance are the data obtained on the depth of reaction penetration as a function of time. Several other parameters were also measured including gaseous product release and transients penetration rate as inferred from thermocouple data.

Discussion of these items will be preceded by a brief discussion of the observations made of each test. These observations will include a brief test commentary and presentation of principal thermocouple, pressure, and atmosphere gas concentration traces.

\section{A. TEST DISCUSSION -- TEST SC-13}

Test SC-13 investigated the effect of sodium hydroxide accumulation on the penetration of sodium into limestone concrete. It had been proposed that water released during the early stages of a sodium-concrete reaction produces sodium hydroxide which forms a separate interactive layer between the sodium and the concrete surface. This test was designed to investigate the potential for this $\mathrm{NaOH}$ layer to penetrate the reaction product layers formed during the early stages of the interaction.

The test was performed by first allowing $870^{\circ} \mathrm{C}\left(1600^{\circ} \mathrm{F}\right)$ sodium to interact with a limestone specimen for 24 hours in the "normal" manner discussed in Section $V$. At the end of the 24 -hour period, $3.6 \mathrm{~kg}$ ( 8 lb) of molten $\mathrm{NaOH}$ at $427^{\circ} \mathrm{C}\left(800^{\circ} \mathrm{F}\right)$ was injected into the sodium pool and allowed to interact freely for a period of 2 hours, after which the reaction was terminated by decanting the sodium and hydroxide.

Sodium pool thermocouples indicated increased temperatures (see Figure 9) shortly following addition of the $\mathrm{NaOH}$. Concrete thermocouples gave no indications of response to the addition of the $\mathrm{NaOH}$. Evaluation of the data, coupled with post-test inspection, indicates that the hydroxide 


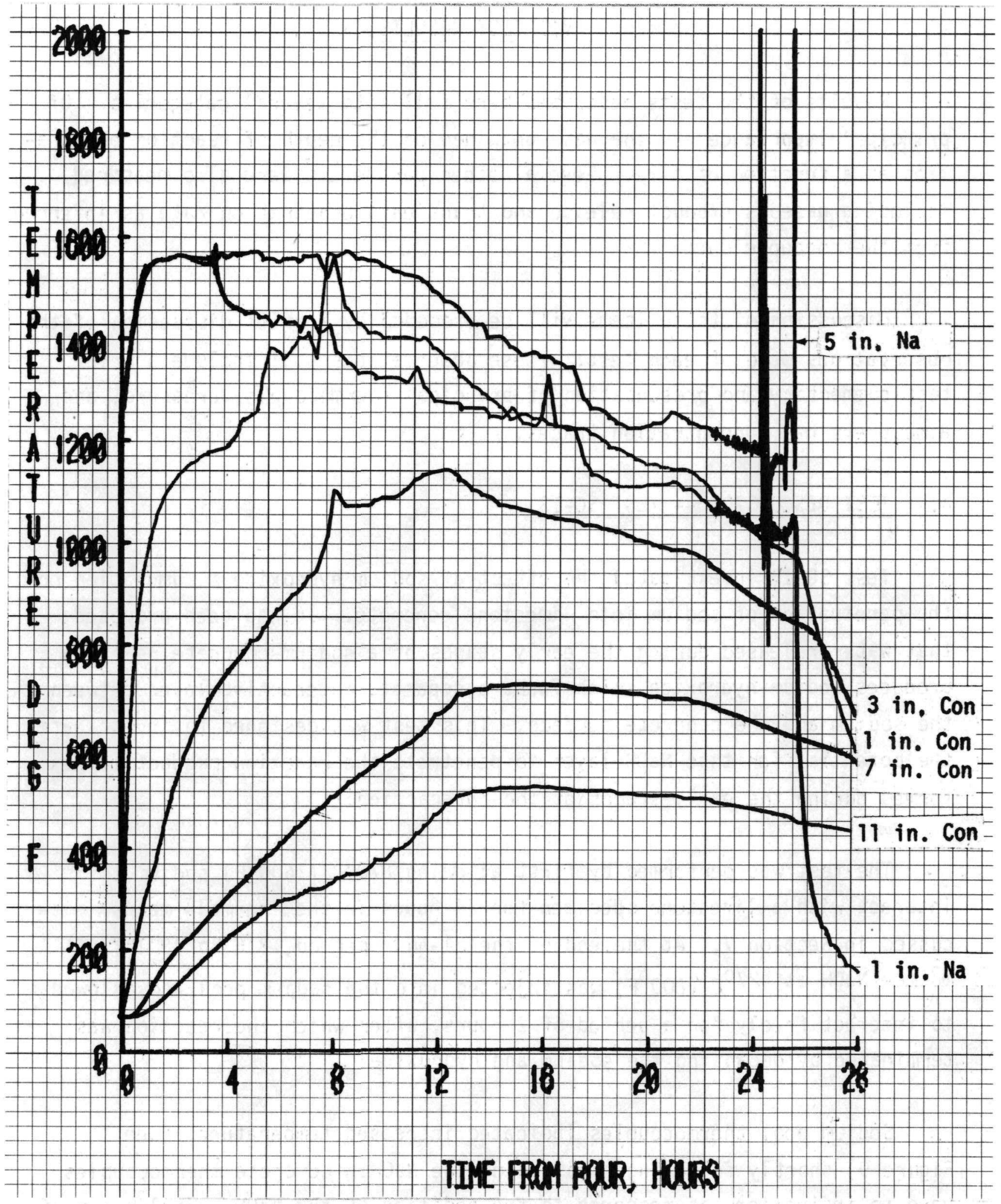

FIGURE 9. SC-13 System Temperatures. 
reacted exothermically with some of the reaction product layer, but that the energies and time extent of the interaction and the masses of the affected materials were small.

Figure 10 indicates cell pressure during test SC-13.

Post-test inspection showed that the sodium hydroxide did not penetrate the reaction product layer which developed prior to the sodium hydroxide injection. This layer had developed to a thickness in the range from 3.8 to $5.1 \mathrm{~cm}$ ( 1.5 to $2 \mathrm{in.}$ ). Samples of the layer showed it to have a density between 1.96 and $2.44 \mathrm{~g} / \mathrm{cc}$. Total sodium content of the material was analyzed to be $24 \mathrm{w} / 0$ and approximately $25-30 \mathrm{w} / 0$ as $\mathrm{Na}_{2} \mathrm{CO}_{3} \cdot$ One sample yielded $11.7 \mathrm{w} / 0$ free carbon, while the other two samples showed 0.4 and $0.7 \mathrm{w} / 0$ free carbon. The high carbon content of the one sample would be expected given a reduction of sodium carbonate by sodium to form sodium oxide and free carbon. This reaction is a substantial energy producer, and the hydroxide could have accelerated the reaction by dissolving the $\mathrm{Na}_{2} \mathrm{CO}_{3}$, thereby increasing its availability to the sodium.

Penetrations observed were $4.4 \mathrm{~cm}(1.75 \mathrm{in.})$ on the average with a local maximum of $7.6 \mathrm{~cm}$ ( 3 in.). Figures 11 and 12 show the concrete specimen after a portion of the reaction product layer had been removed and a hole observed in the center of the specimen. Substantial cracking was noted throughout the test article, some of which is seen in the photographs. Several of these cracks were observed in the region of the hole in the center. A large number of separated chunks were observed on the suface between the solid specimen and reaction product layer.

\section{B. TEST DISCUSSION -- TEST SC-14}

Test SC-14 also investigated some of the effects of hydroxide accumulation in the bulk sodium pool on the overall rate and extent of the reaction. This test was performed by adding $3.6 \mathrm{~kg}(8 \mathrm{lb})$ of reagent grade, dry sodium 


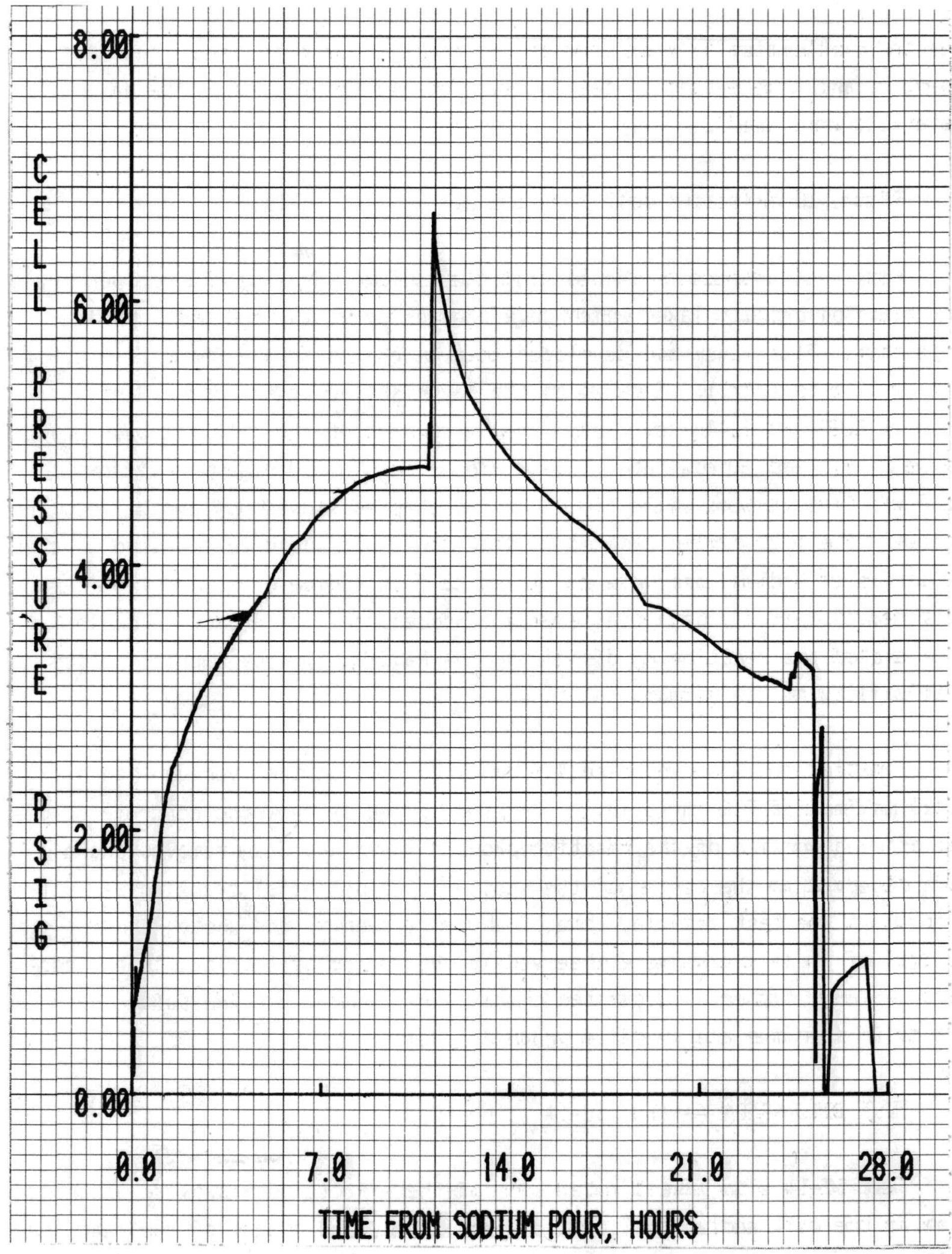

FIGURE 10. SC-13 Cell Pressure and Indicated Hydrogen Concentration. 


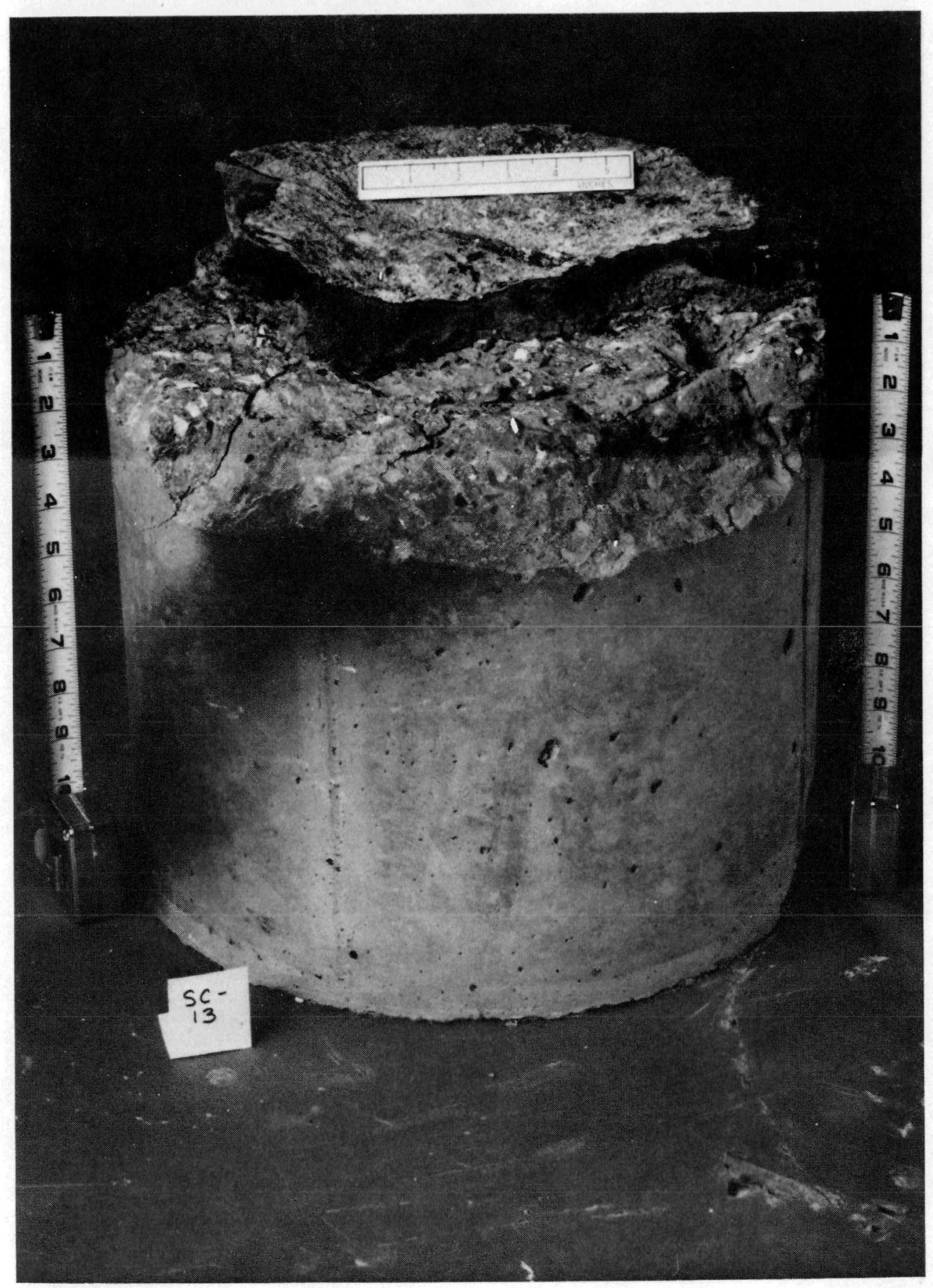

FIGURE 11. SC-13 Test Specimen.

Neg 7712206-5cn 


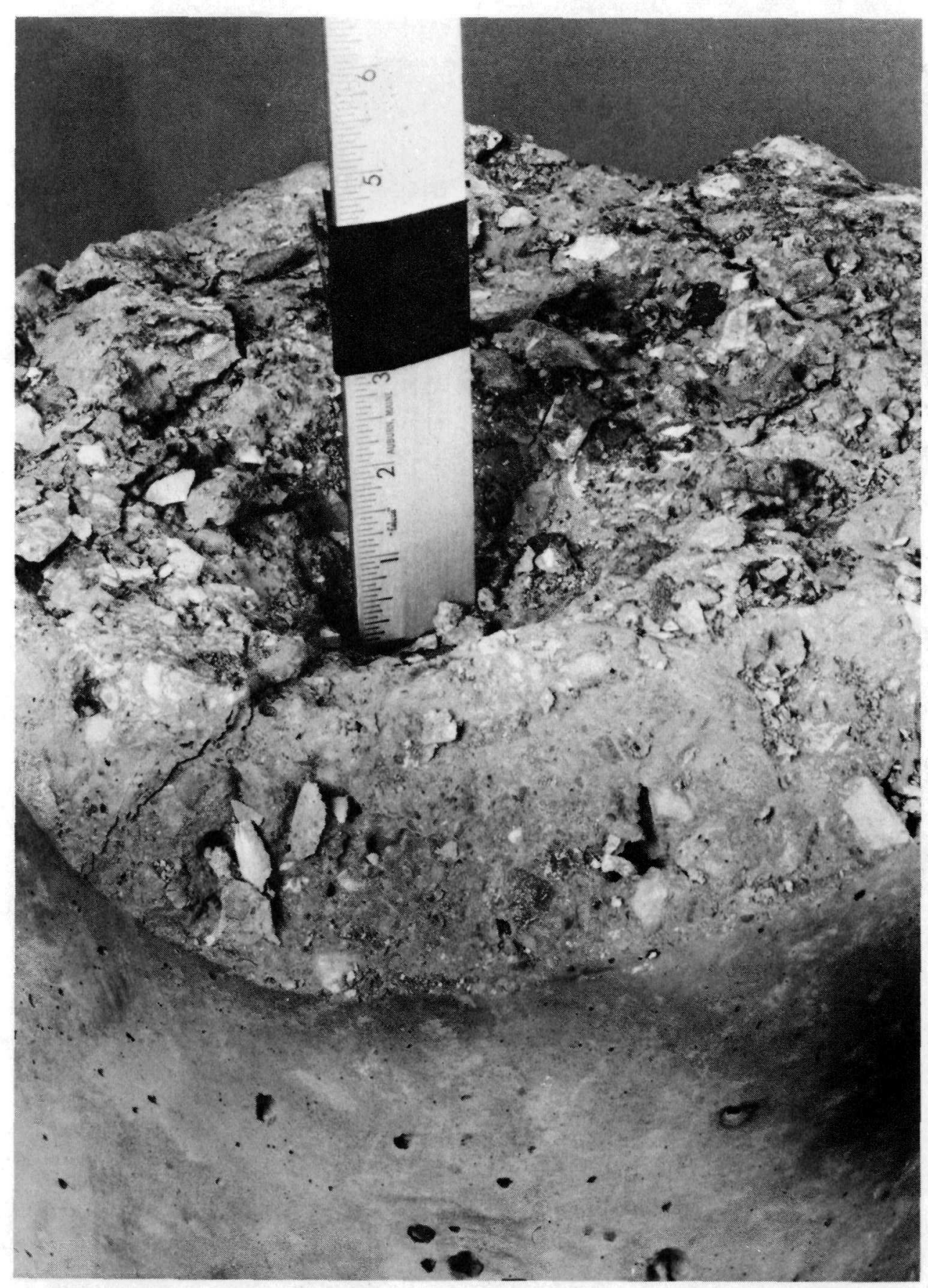

FIGURE 12. Detail on the Surface of the SC-13 Test Specimen. Neg 7712766-1cn 
hydroxide pellets above the concrete surface prior to the $871^{\circ} \mathrm{C}\left(1600^{\circ} \mathrm{F}\right)$ sodium transfer. The test was maintained at $871{ }^{\circ} \mathrm{C}\left(1600^{\circ} \mathrm{F}\right)$ for 24 hours and then decanted. The sodium hydroxide constituted $14 \%$ by weight $\mathrm{NaOH}$ in solution with metallic sodium at the start of the test.

Thermocouple measurements showed interesting detail throughout the heated portion of the test. At one hour, the $2.5-\mathrm{cm}\left(1-\mathrm{in}_{\text {. }}\right)$ concrete thermocouple indicated an increase in the rate of temperature rise at that location. At 2-3/4 hours into the test, the same thermocouple indicated a moderately strong $83^{\circ} \mathrm{C}\left(150^{\circ} \mathrm{F}\right)$ excursion, followed by erratic response about a generally asymptotic temperature profile. Simultaneously, the $2.5-\mathrm{cm}(1-\mathrm{in}$.$) sodium thermocouple indicated a sharp 28^{\circ} \mathrm{C}\left(50^{\circ} \mathrm{F}\right)$ increase, followed by several oscillations between 593 to $793^{\circ} \mathrm{C}\left(1100\right.$ and $\left.1460^{\circ} \mathrm{F}\right)$. The final excursion of the group was followed by an exponential approach to the original temperature indications. The excursions lasted $1 / 2$ hour. Although similar response was not observed in the pressure or hydrogen curves, it is reasonable to assume that a local reaction, perhaps a spalling event, occurred at or very near the location of the 2.5-cm (1-in.) sodium and concrete thermocouples. Other system temperatures showed smoother response to the transient. The deeper concrete temperatures indicated water release points. The $7.6-\mathrm{cm}\left(3-\mathrm{in}_{\text {. }}\right)$ concrete thermocouple showed response to some of the more severe transient events noted at the 2.5-cm (1-in.) leve1, indicating that the $2.5 \mathrm{~cm}\left(1-\right.$ in. $\left._{0}\right)$ fluctuations were in response to events liberating observable energy. The temperature responses are sumarized in Figure 13.

Maximum observed hydrogen concentration was $33.8 \%$ at about 15 hours, as shown in Figure 14. Maximum cell pressure was $12 \mathrm{KPag}(1.75 \mathrm{psig})$ at 10 hours. At 10 hours, the hydrogen concentration was $32 \%$ and the cell temperature was $38^{\circ} \mathrm{C}\left(100^{\circ} \mathrm{F}\right)$ giving $5-8 \mathrm{~kg}(15 \mathrm{lb}) \mathrm{H}_{2}$ in the cell at that time. The cell was not well sealed during the test. Therefore, this is a lower bound to the hydrogen released during the test. 


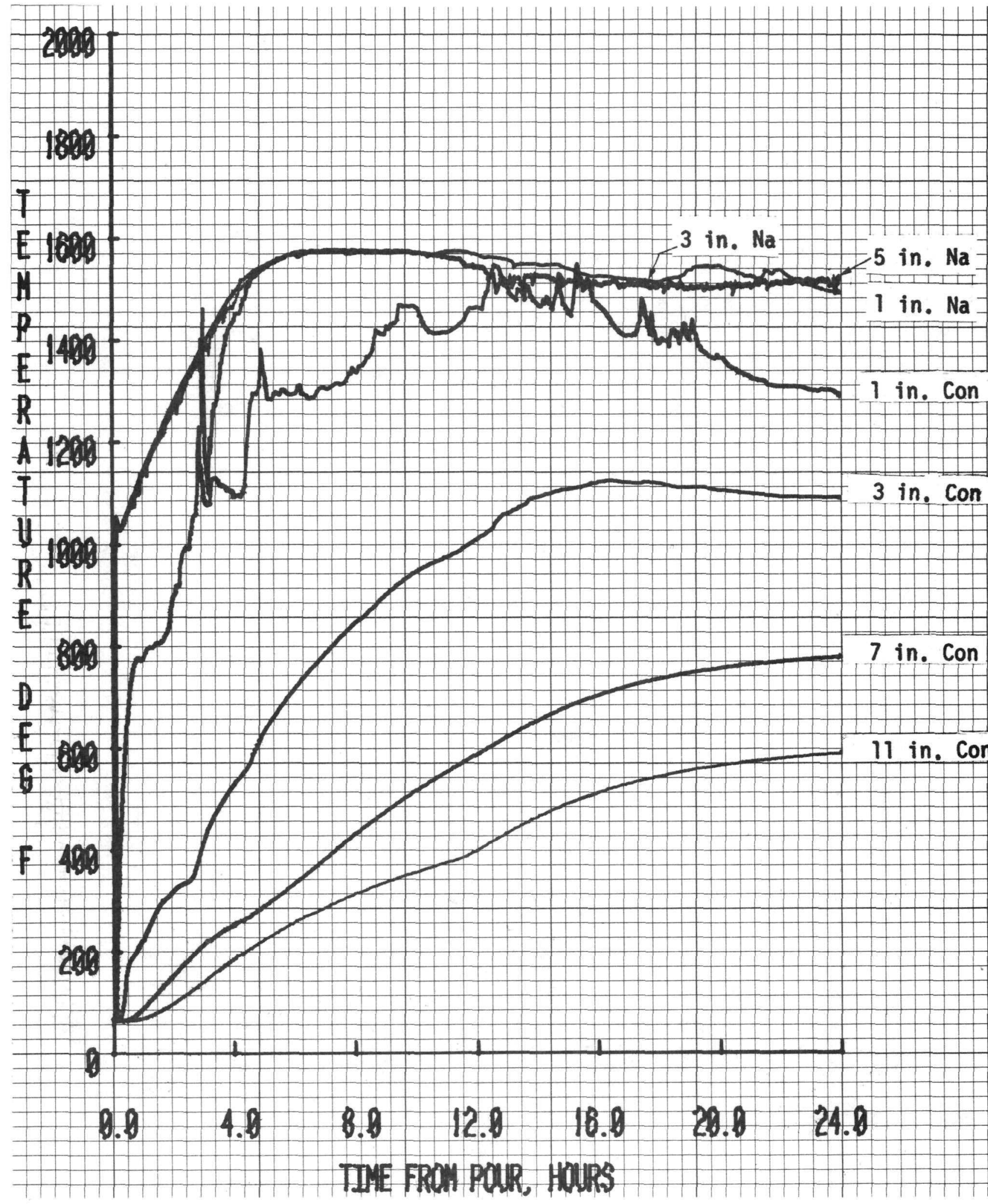

FIGURE 13. SC-14 System Temperatures. 


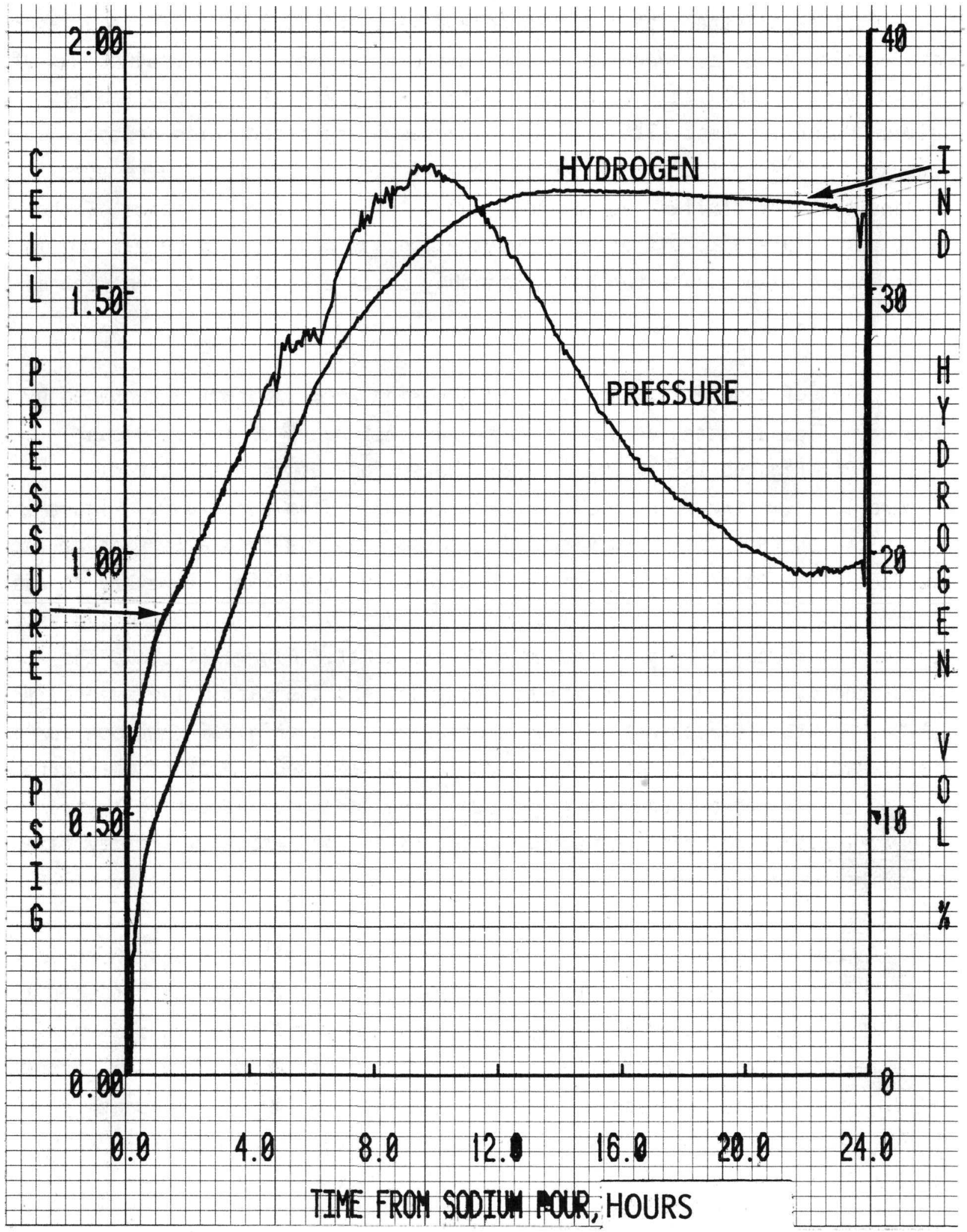

FIGURE 14. Cell Pressure and Indicated Hydrogen Concentration. 
Post-test inspection revealed on ly a very thin $0.3 \mathrm{~cm}(1 / 8-$ in. $)$ layer of reaction products adhering to the concrete surface. This product was of higher density than that observed during SC-13 ( $2.7 \mathrm{vs} 2.2 \mathrm{~g} / \mathrm{cc})$ and of higher $\mathrm{Na}_{2} \mathrm{CO}_{3}$ content ( $31 \%$ vs $27 \%$ ). The resulting penetration depths, average of $5.7 \mathrm{~cm}(2.25 \mathrm{in.})$ and maximum of $8.4 \mathrm{~cm}(3.3 \mathrm{in.})$, were more severe than for similar test without $\mathrm{NaOH} .{ }^{(1)}$ The characteristics of the penetration are also different. Penetration was observed to be maximum in the center, with the center being smoothly concave relative to the rest of the surface.

Chips of concrete caused by edge cracking were apparently consumed by the $\mathrm{NaOH}$ flux assisted mechanism, a feature not noted during previous tests. (1) Figures 15, 16 and 17 show the surface of the test article. Figure 15 shows the surface after removing the sodium reservoir. Figure 16 shows the surface after removing the reaction residue from a portion of the surface. The layer can be seen to be generally very thin. However, it was found to be quite adherent to the concrete and a very thin $0.3-\mathrm{cm}\left(1 / 8-\mathrm{in}_{\text {. }}\right)$ concrete surface layer was removed with the crust. Figure 17 shows the unreacted concrete after removal of the crust and the cask. The generally concave center is apparent in this photograph. The original concrete surface is at " 0 " on the rulers on either side of the specimen. Most of the surface irregularities were rounded off and none were "sharp", indicating that chemical attack was rapid compared to any "spalling" attack which may have contributed to the penetration.

In comparison with test SC-13 and previous tests $(1)$, it was observed that the sodium hydroxide injected at the start of the reaction produced a more rapid and slightly deeper penetration of concrete than did sodium alone or a later accumulation of $\mathrm{NaOH}$. However, the ultimate penetration depths of $5.8 \mathrm{~cm}$ (2.3 in.) average and $8.4 \mathrm{~cm}(3.3 \mathrm{in.}$ ) maximum are reasonably $(50 \%)$ in agreement with those observed for simple sodium attack ${ }^{(1)}$ with $4.3 \mathrm{~cm}$ (1.7 in.) average and $5.3 \mathrm{~cm}(2.1 \mathrm{in.})$ maximum. 


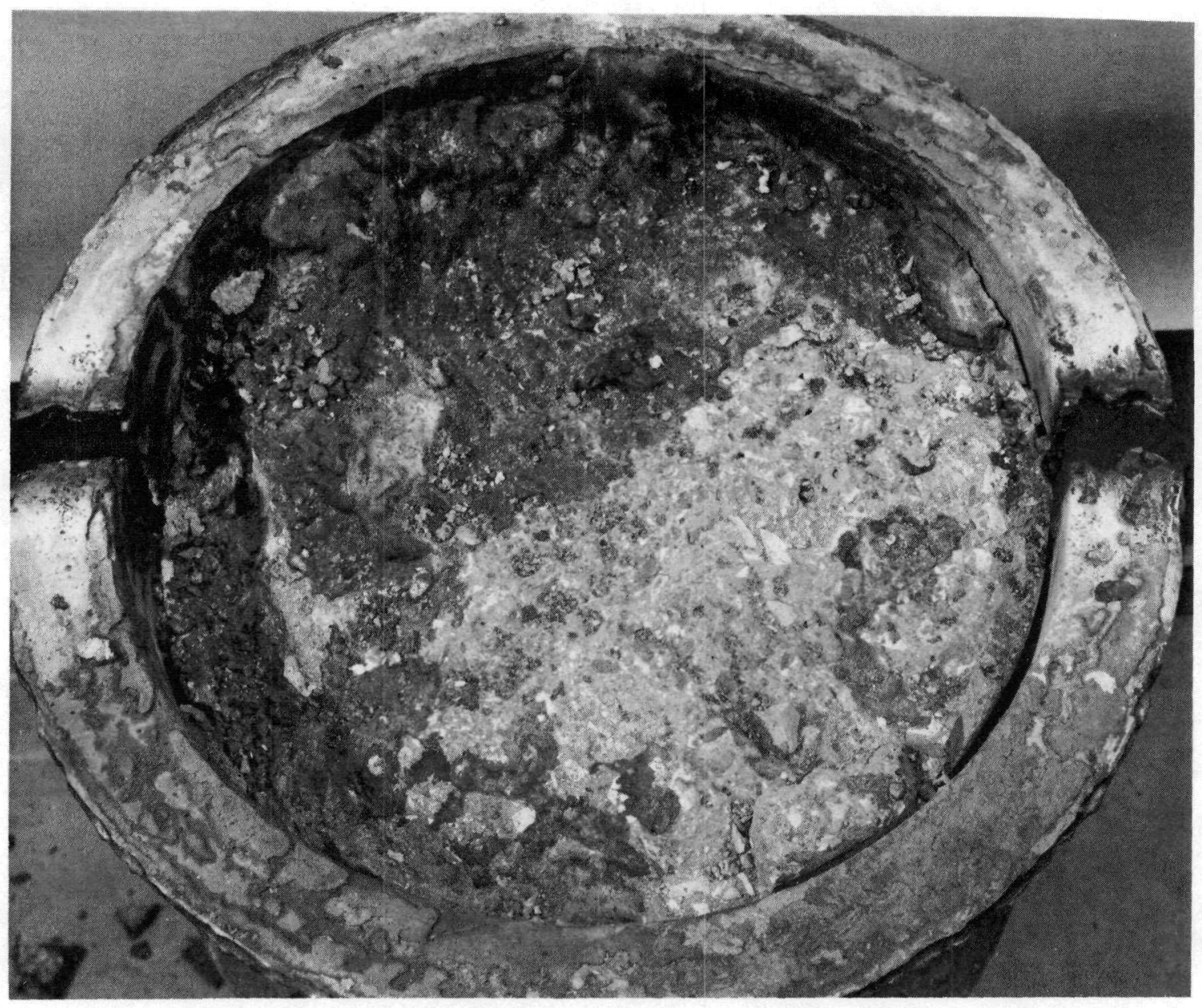

FIGURE 15. Surface of Test Specimen SC-14.

Neg 78A144-6cn 


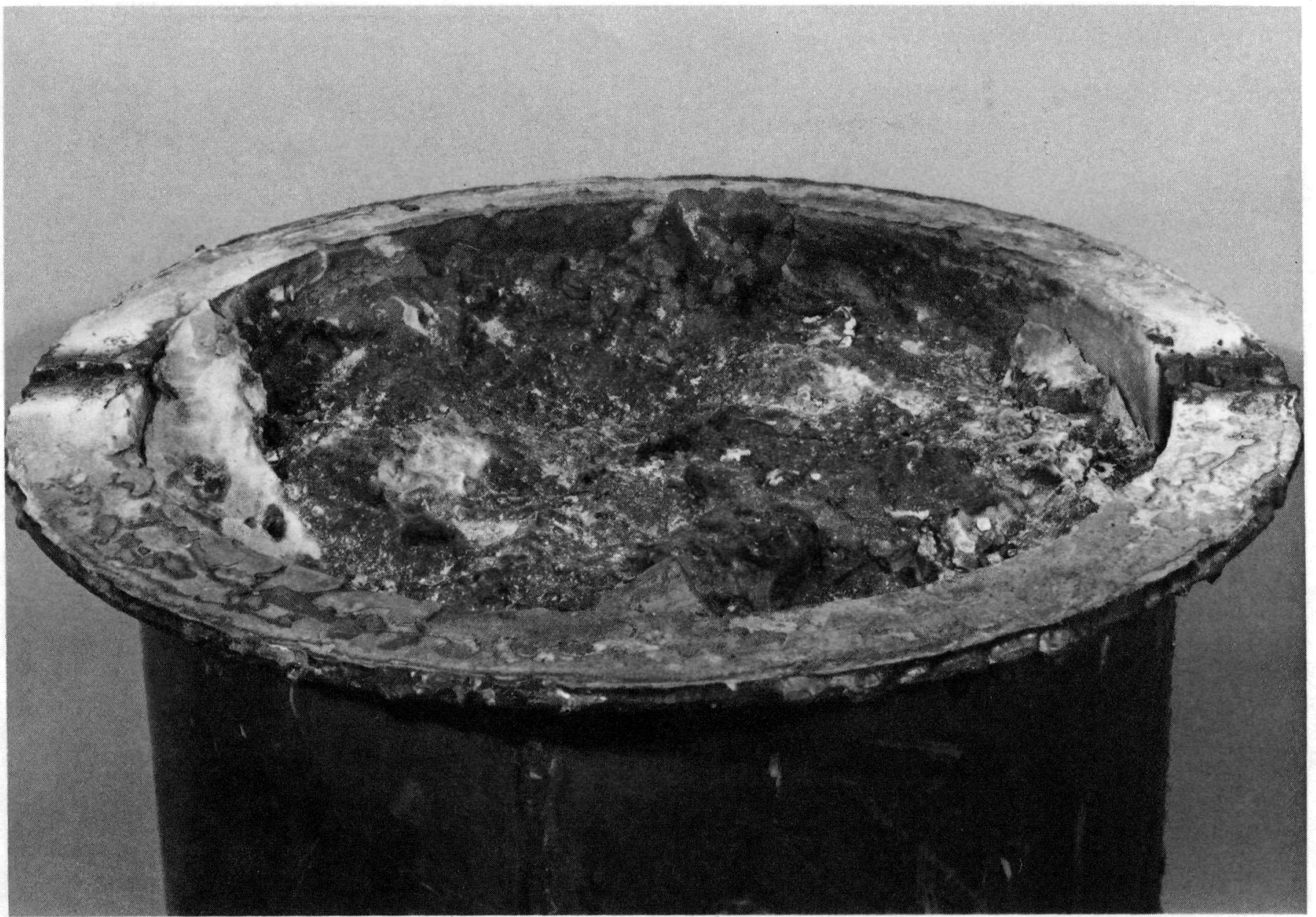

FIGURE 16. Surface of Test Specimen SC-14 After Removal of Residue.

Neg 78A144-1cn 


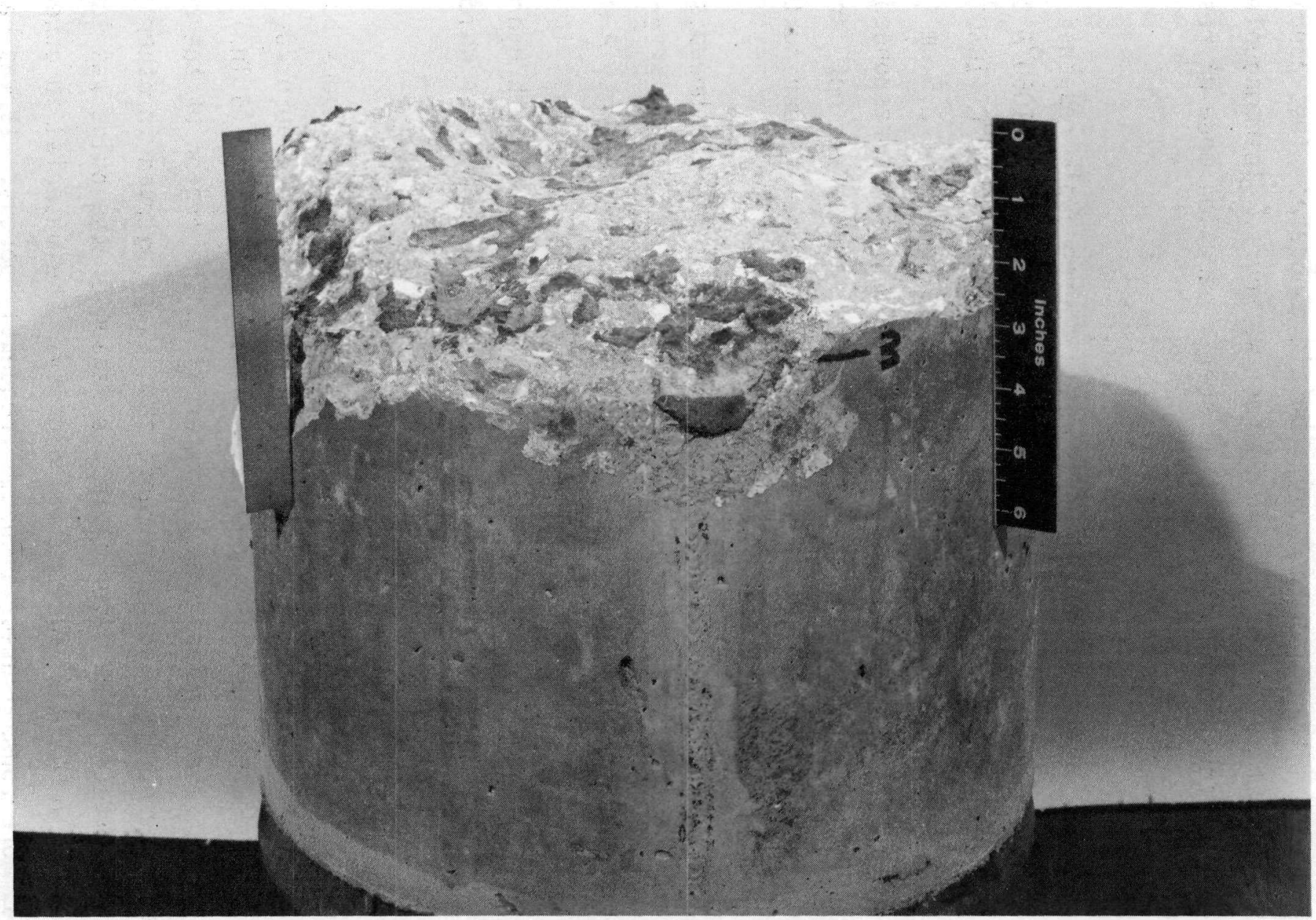

FIGURE 17. Unreacted Concrete of Test Specimen SC-14. 


\section{TEST DISCUSSION -- TEST SC-15}

Test SC-15 was the first test using basalt concrete. Test conditions included a temperature of $871^{\circ} \mathrm{C}\left(1600^{\circ} \mathrm{F}\right)$ for two hours. Thermocouple responses in the concrete showed a normal heat conduction mode of response to the pour during the first 40 minutes.

At that time, the $2.5-\mathrm{cm}$ (1-in.) concrete thermocouple response (Figure 18) showed a discontinuous jump from $566^{\circ} \mathrm{C}$ to $732^{\circ} \mathrm{C}\left(1050^{\circ} \mathrm{F}\right.$ to $1350^{\circ} \mathrm{F}$ ) followed three minutes later by a sharp spike to $582^{\circ} \mathrm{C}\left(1080^{\circ} \mathrm{F}\right)$ and back up. This response indicates a local penetration to the $2.5-\mathrm{cm}(1-\mathrm{in}$. depth at 40 minutes into the test. No other thermocouples responded to this event, indicating that any associated energy release was not large. The $7.5-\mathrm{cm}(3-$ in. $)$ concrete thermocouple proved to be faulty during the test.

Pressure and hydrogen response curves seen in Figure 19 showed some detail of interest. The pressure showed a decrease immediately after completion of the pour, in response to the cell atmosphere cooling. A moderate increase in slope was observed 35 minutes into the test, but this increase was not correlated with temperatures in the test article or with hydrogen response. The hydrogen response showed one event at 55 minutes which was not correlated with other data.

Post-test inspection of the test article showed a conspicuous bulge in the cask surrounding the concrete section, as shown in Figure 20 . The bulge extended downward from the concrete surface by $15.2 \mathrm{~cm}$ ( 6 in.). As Figure 21 shows, the reaction product material in the region of the bulge has a much different physical appearance than that observed in other portions of the surface. The material in the region of the bulge was loose, black and friable, with a low apparent density. The material in other regions was more consolidated, although frequently porous. It was harder, lighter in color, and appeared more dense than the material from the bulge. Chemical analyses of the various materials showed actual specific gravities to be all within the range of 2.42 to 2.69 . Total sodium contents ranged 


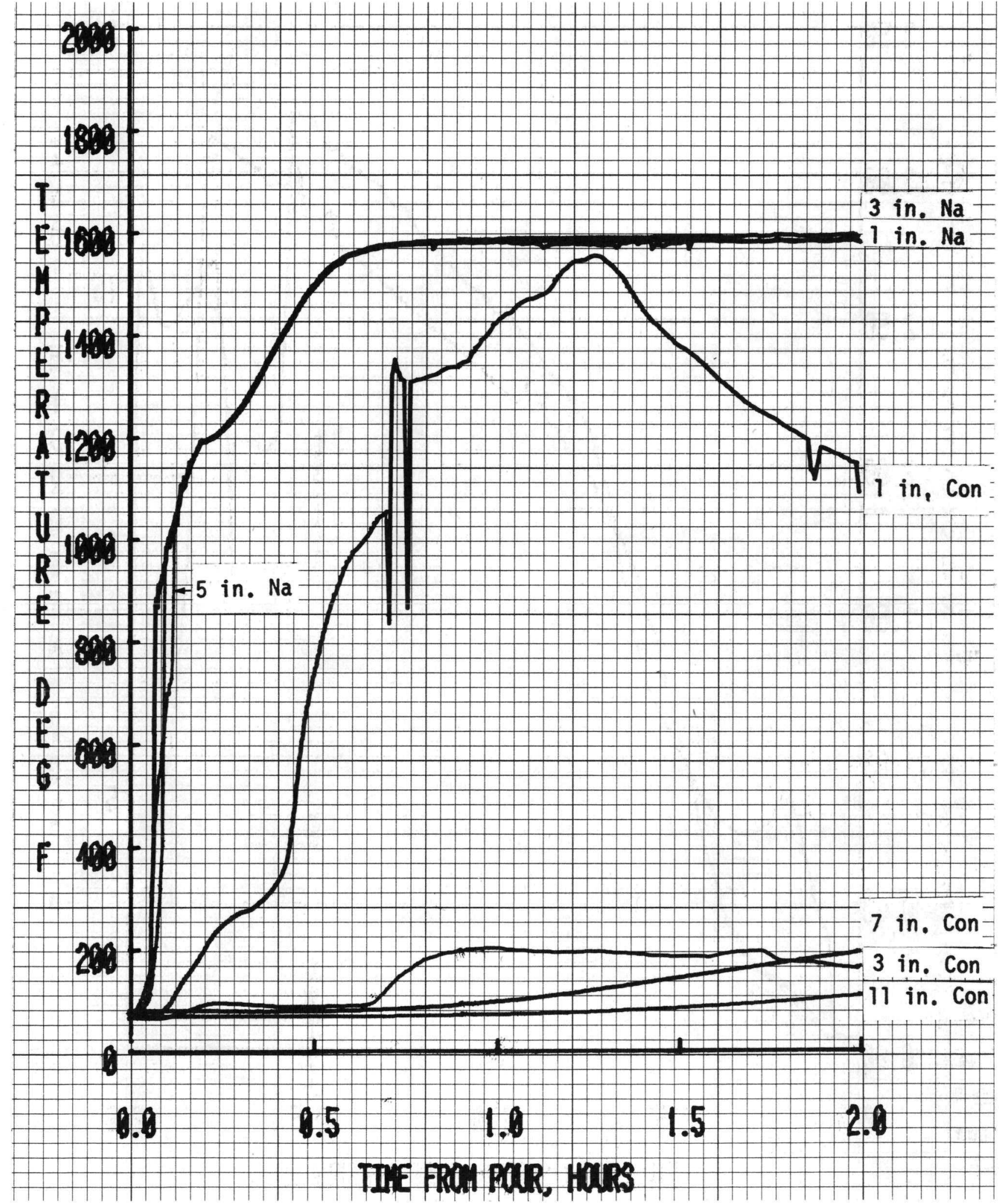

FIGURE 18. SC-15 System Temperatures. 


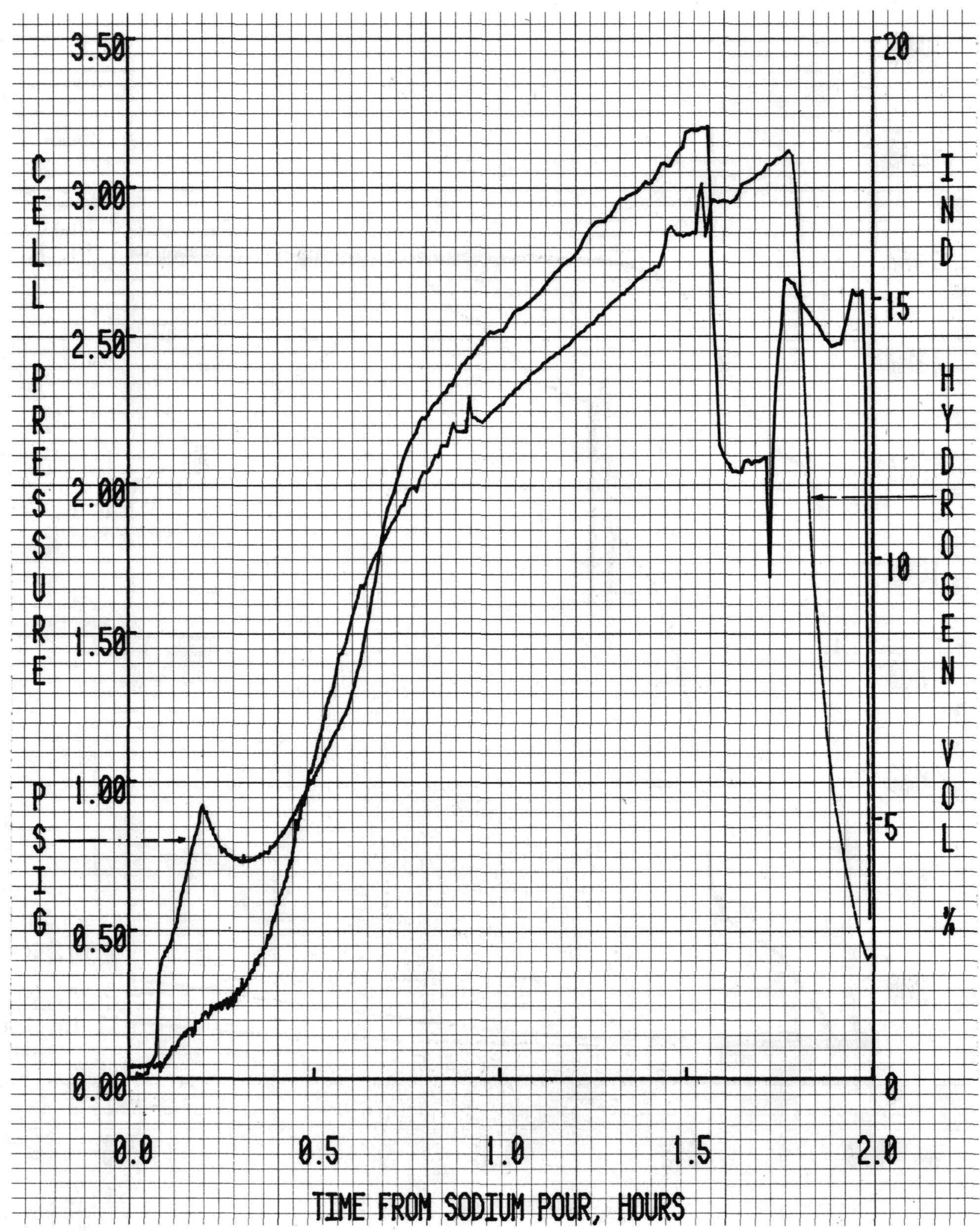

FIGURE 19. SC-15 Cell Pressure and Indicated Hydrogen Concentration. 


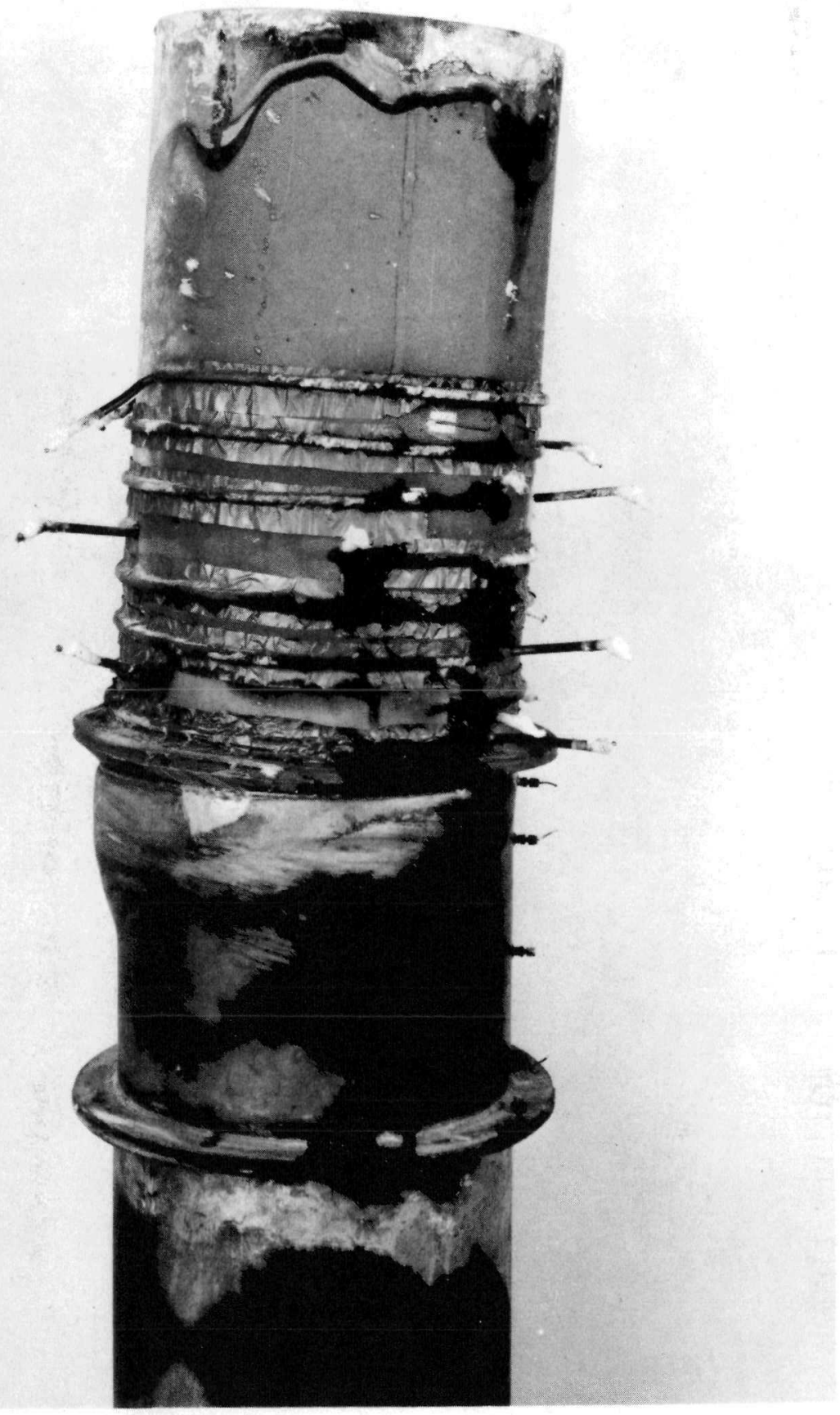

FIGURE 20. SC-15 Test Article Before Disassembly.

Neg 7801970-2cn 


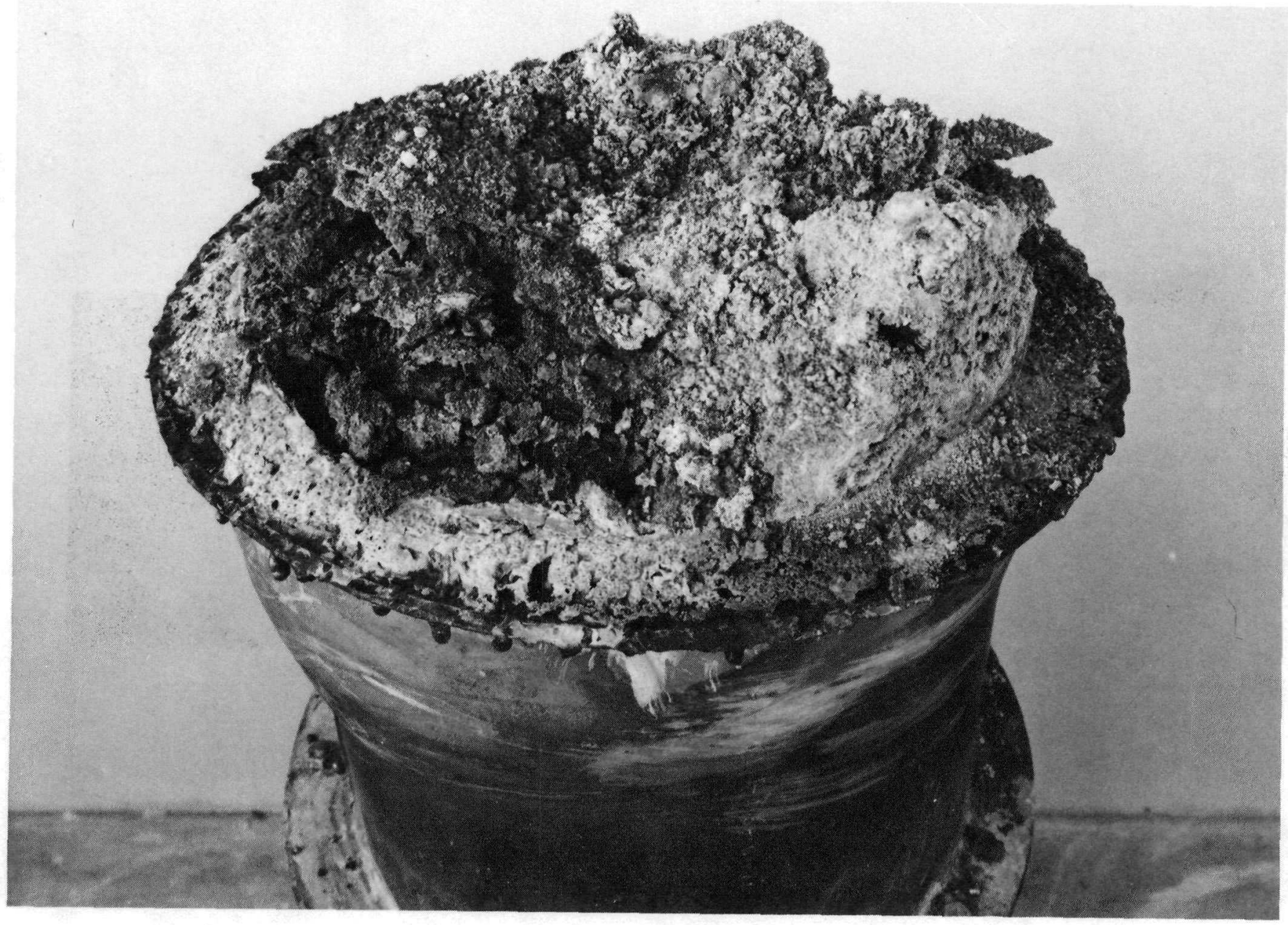

FIGURE 21. Reaction Product Residue on Test SC-15 Concrete Sample.

Neg 781970-3cn 
from $40 \%$ near the top of the residue to $20 \%$ nearest the concrete and in the bulge residue. Sodium hydroxide concentration was generally higher near the top of the reaction produced $(40-70 \%)$ and lower near the bottom $(20-40 \%)$. Material near the concrete was higher in $\mathrm{Fe}, \mathrm{Al}$ and $\mathrm{Si}$ than in other locations, and the buige residue was very high in $\mathrm{Fe}$ and $\mathrm{Si}$, but low in soluble Si.

It is believed that the reaction observed on the side walls was promoted by the low strength of the steel at the $871^{\circ} \mathrm{C}\left(1600^{\circ} \mathrm{F}\right)$ operating temperature. A minor side reaction in this region of generally limited sodium access produced a solid reaction product more voluminous than the original material, which produced the distortion observed. This distortion allowed additional sodium entry into the region to continue the process.

Figure 22 shows the concrete specimen after removing the cask and reaction products. The local penetration where the bulge was shows the effects of this two dimensional attack very clearly. Ignoring the local effects at the wall, an apparent average penetration of $3.18 \mathrm{~cm}(1.25 \mathrm{in.})$ was observed. In the center of the photo can be seen an area of chemical reaction below a flake of concrete at $2.5-\mathrm{cm}\left(1-i_{\text {. }}\right)$ level. This piece appeared to have cracked partly through but is not completely removed from the surface; limited reaction on its underside was observed.

\section{TEST DISCUSSION -- TEST SC-16}

Test SC-16 exposed a basalt test article to $871^{\circ} \mathrm{C}\left(1600^{\circ} \mathrm{F}\right)$ sodium for 8 hours. No unusual observations were made during the heated portion of the test. As the temperature traces (Figure 23) show, a possible penetration to the $2.5-\mathrm{cm}(1-\mathrm{in.})$ thermocouple may have occurred at 1.8 hours into the test. The $7.6 \mathrm{~cm}\left(3-\right.$ in. $\left._{\text {. }}\right)$ thermocouple demonstrated similar behavior at 4 hours into the test. 


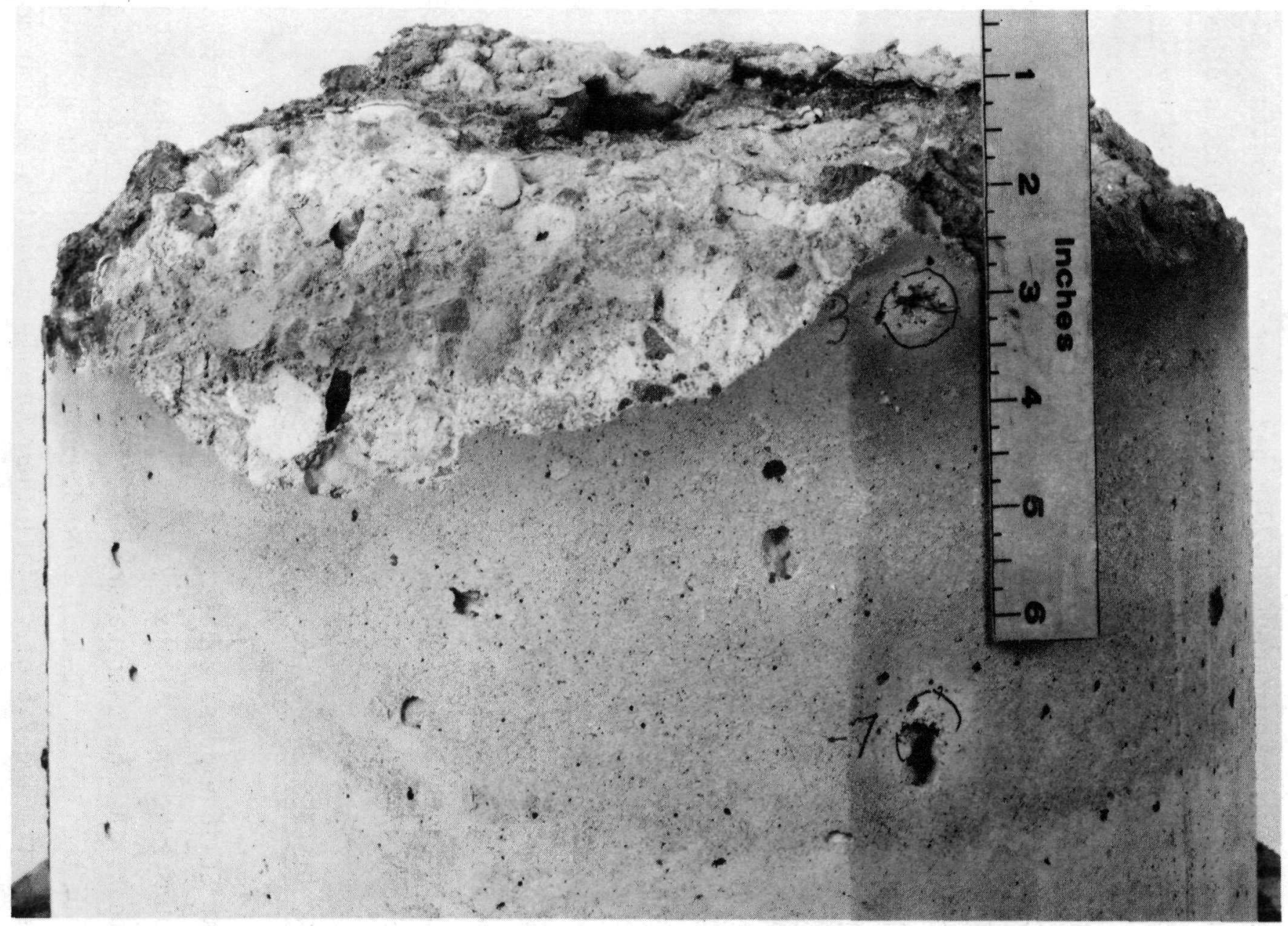

FIGURE 22. Surface of Unreacted Concrete from Test SC-15.

Neg 7801970-12cn 


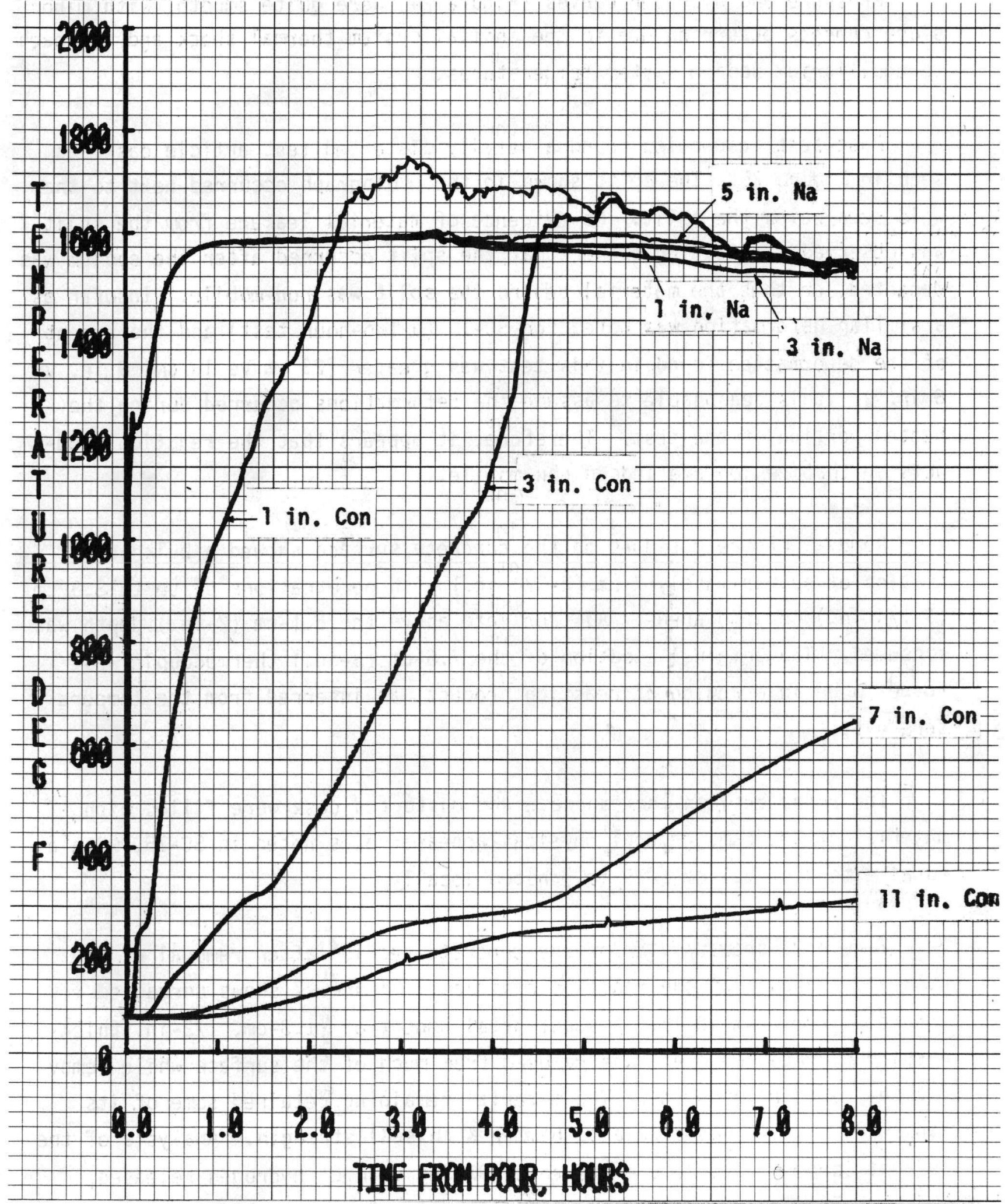

FIGURE 23. SC-16 System Temperatures. 
Pressure and hydrogen curves (Figure 24) were quite smooth, with minor slope changes occurring due to the initial system thermal shock and approach to equilibrium sodium system temperatures.

Post-test inspection found a heavily distorted test article cask, as seen in Figure 25. The split shown in the photograph occurred next to the weld seen below the split. No evidence of material leakage from the split was observed, indicating either that the split occurred after the sodium was decanted, or that the material behind the split was non-mobile. Insofar as a similar deformation was noted for SC-15 (a two-hour test) and the extent of the deformation found in this test was greater $(23 \mathrm{~cm}$ vs $15 \mathrm{~cm} 9$ in. vs 6 in. ), it is reasonable to assume the deformations occurred during the heated portion of the test. Therefore, it appears that the reaction products in that region are indeed non-mobile.

Removal of the residues on the concrete surface showed a bulk penetration of approximately $7 \mathrm{~cm}(2-3 / 4 \mathrm{in}$.) with penetrations of up to $8.3 \mathrm{~cm}$ (3-1/4 in.) in some areas. Al1 concrete above the 5.1-cm (2-in.) depth was consumed. The original location of the $7.6-\mathrm{cm}(3-i n$.$) thermocouple was$ found to be in a region of reaction product, as inferred from the temperature data.

The areas between the concrete and distorted cask were filled with material of the same general physical appearance as noted in SC-15, with a total extent of $2.3 \mathrm{~cm}(0.9$ in.) noted locally.

Figure 26 shows a view of the concrete section after removal of the cask and the bulk of the reaction residues. Figure 27 shows unreacted concrete from test SC-16. A substantial amount of (1.3-cm, 1/2-in. thickness) dehydrated concrete was removed from much of the surface while removing the reaction products. The material remaining retained some of its "apparent" (i.e., resistance to hanmer \& chisel) strength. Analysis of the ce 11 atmosphere grab sample showed $22.9 \%$ (by volume) hydrogen released, which at $58 \mathrm{KPag}(8.4 \mathrm{psig})$ and $43^{\circ} \mathrm{C}\left(110^{\circ} \mathrm{F}\right)$ ce 11 temperature represents 


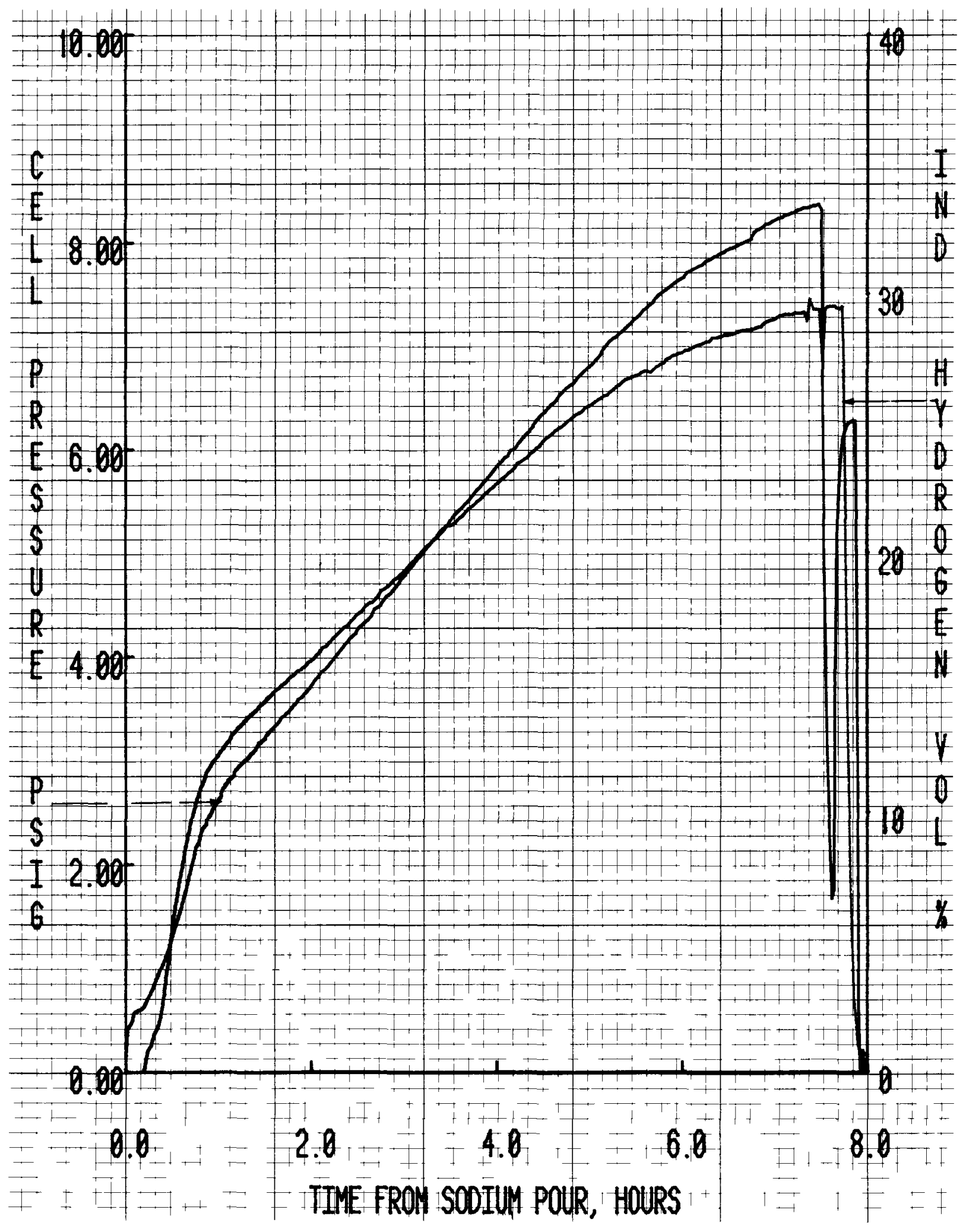

FIGURE 24. SC-16 Cel1 Pressure and Indicated Hydrogen Concentration 


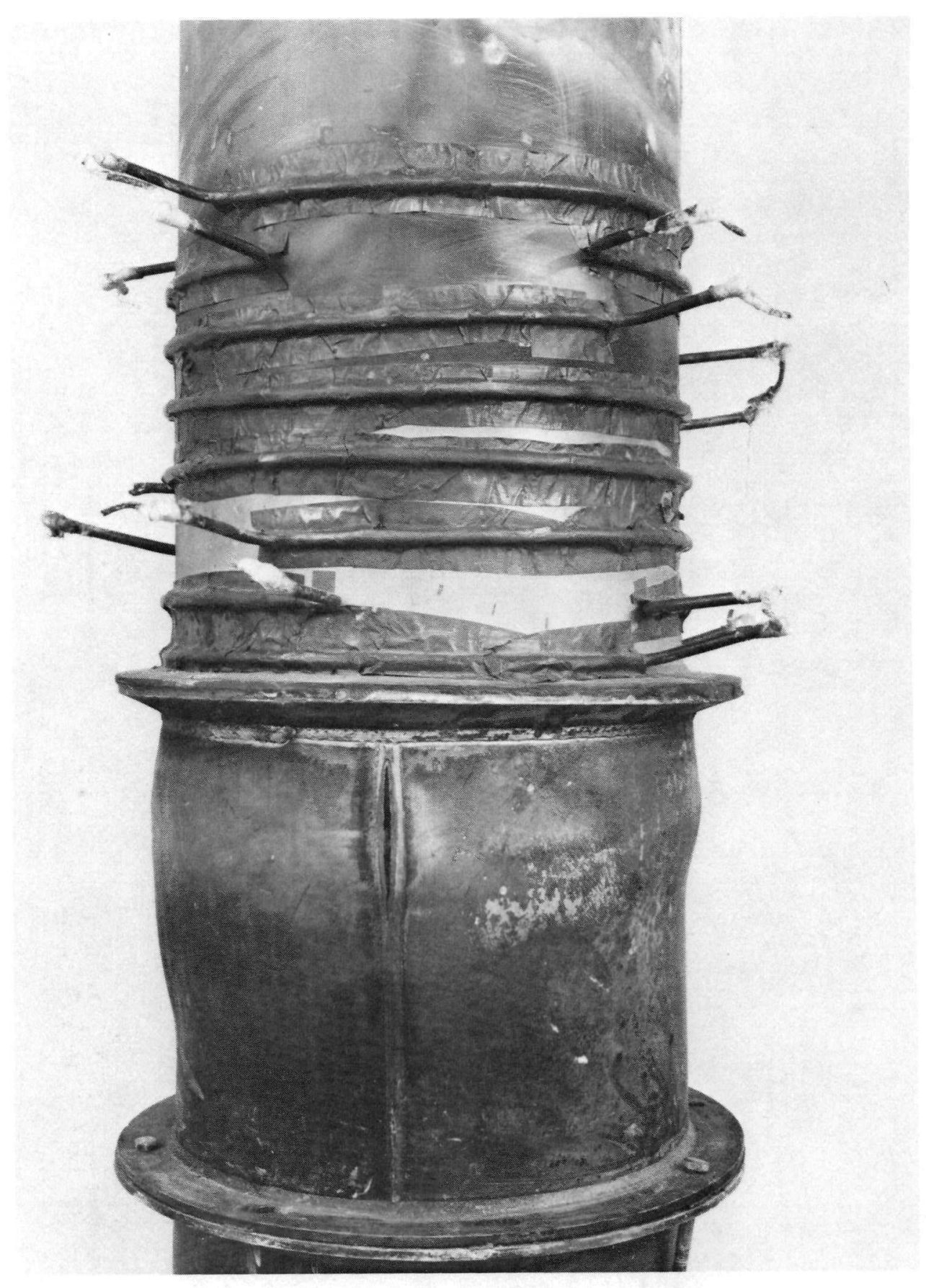

FIGURE 25. Test Article from SC-16 Before Disasssembly. Neg 7862017-10cn 


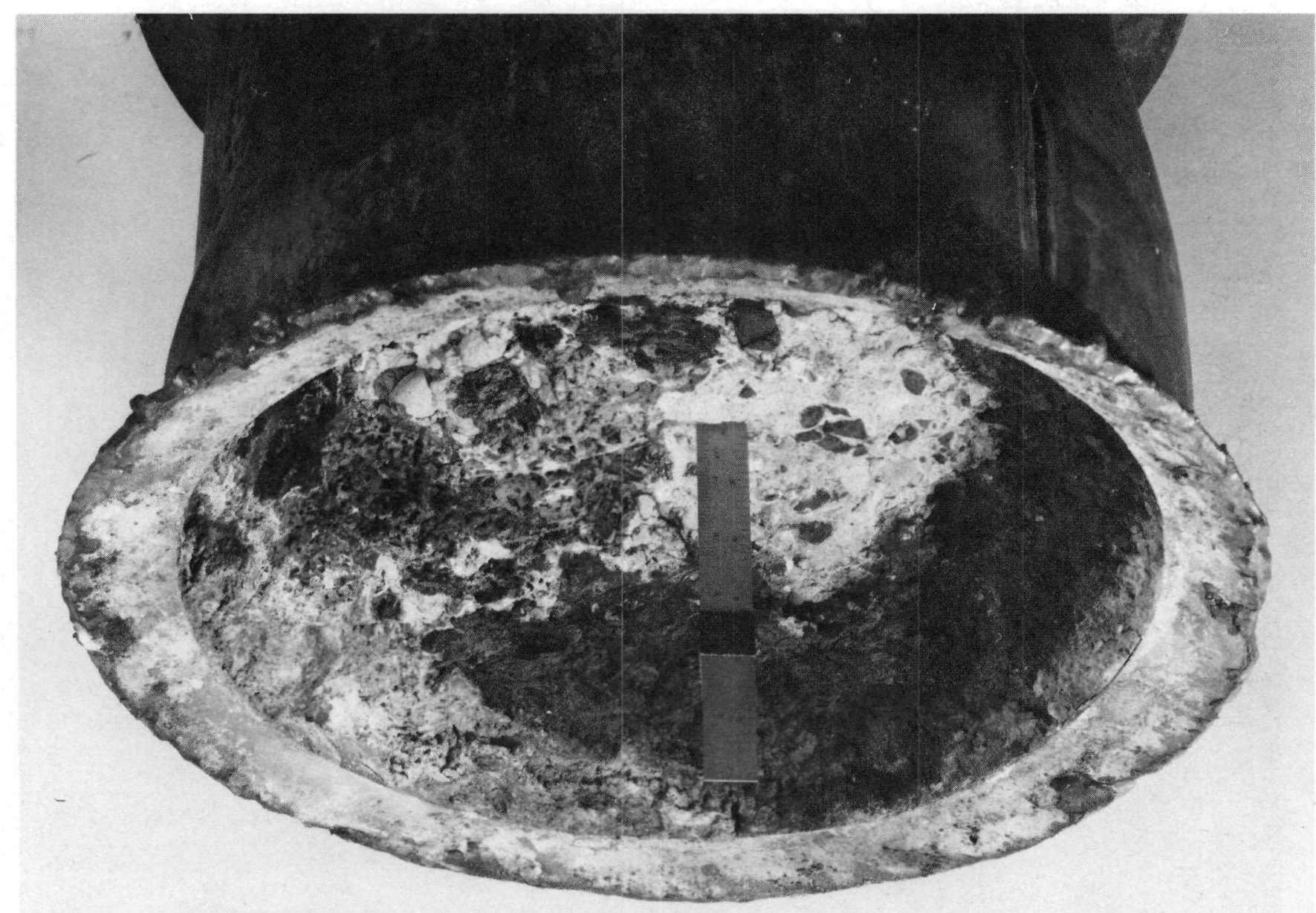




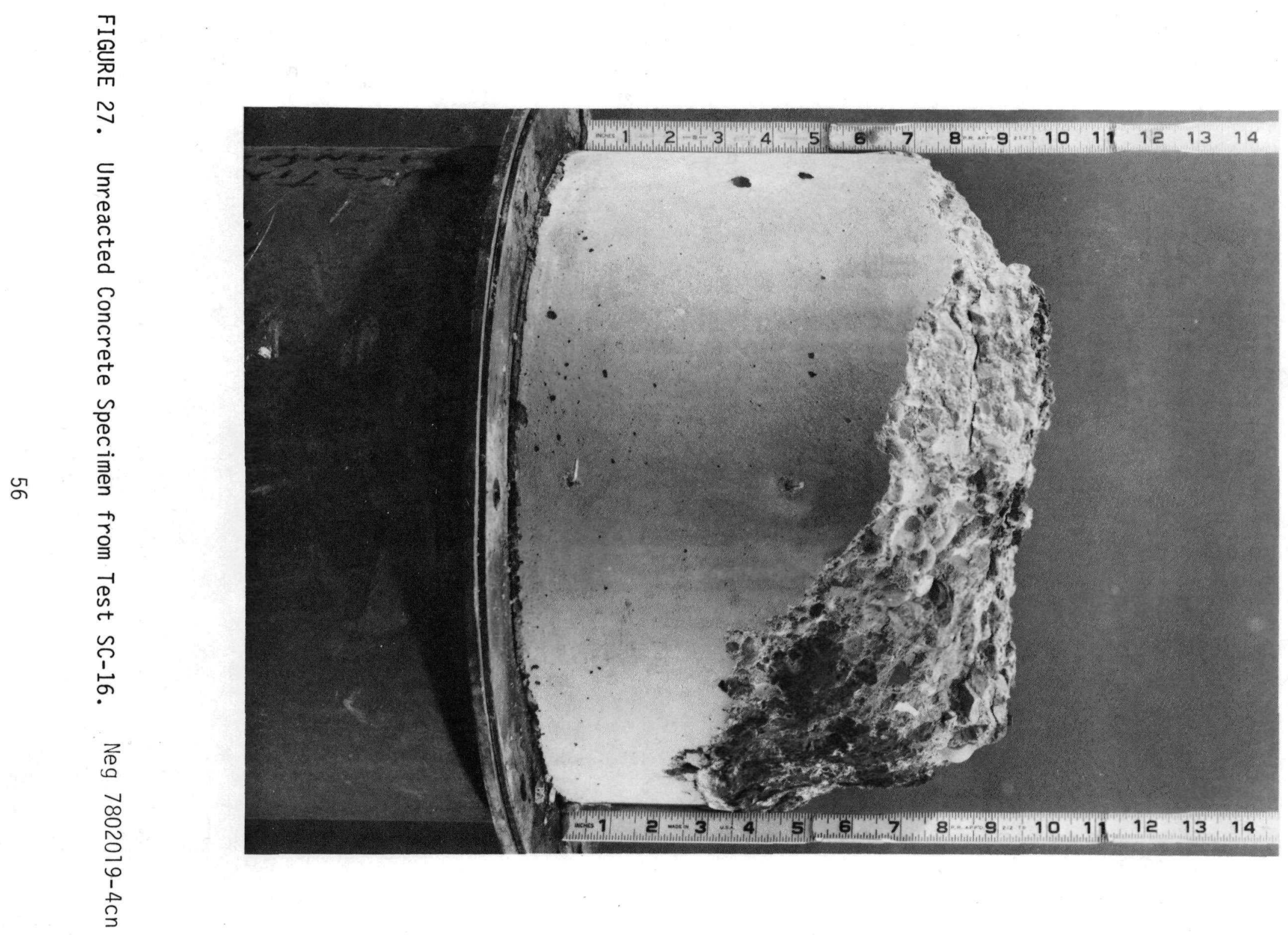


0.6 pound-moles $\mathrm{H}_{2}$, or $60 \%$ of the hydrogen available from the water in the concrete.

\section{E. TEST DISCUSSION -- TEST SC-17}

Test SC-17 was to be a 24 -hour test with basalt concrete. Difficulties prohibited immediate transfer of the total $22.7 \mathrm{~kg}$ (50 lb) sodium inventory as intended. Approximately 4.5 to $11.3 \mathrm{~kg}$ (10 to $25 \mathrm{lb}$ ) of sodium was injected into the test reservoir before the transfer was terminated. The remaining 11.3 to $18.1 \mathrm{~kg}$ (25 to $40 \mathrm{lb}$ ) was successfully transferred approximately 5 hours into the test. At $T=24$ hours, the test was terminated by decanting in the usual manner.

Figure 28 shows that system temperature response to these test conditions proved quite unusual. During the first 2 hours, responses noted were similar to those generally observed in other tests. The $2.5-\mathrm{cm}\left(1-i_{0}\right)$ concrete thermocouple indicated a possible $2.5 \mathrm{~cm}(1-\mathrm{in.})$ penetration at one hour and showed a temperature rise to $28^{\circ} \mathrm{C}\left(50^{\circ} \mathrm{F}\right)$ above the mean sodium temperature of $857^{\circ} \mathrm{C}\left(1575^{\circ} \mathrm{F}\right)$ at 1.5 hours, indicating an observable exothermic reaction. The temperature at this location quickly decayed to $788^{\circ} \mathrm{C}\left(1450^{\circ} \mathrm{F}\right)$, indicating probable accumulation of a non-interactive insulation reaction product layer in the area.

At the time the concrete $2.5-\mathrm{cm}\left(1-\right.$ in. $\left._{\text {. }}\right)$ temperature decayed to $788^{\circ} \mathrm{C}$ $\left(1450^{\circ} \mathrm{F}\right)(2-1 / 2 \mathrm{hr})$ the sodium $2.5-\mathrm{cm}(1-i \mathrm{n}$.$) level showed an exothermic$ event, elevating the temperature briefly to $882^{\circ} \mathrm{C}\left(1620^{\circ} \mathrm{F}\right)$. In response to this event, the $2.5-\mathrm{cm}(1-\mathrm{in}$.$) concrete temperature ceased its decay and$ began rising slowly to $816^{\circ} \mathrm{C}\left(1500^{\circ} \mathrm{F}\right)$. The $2.5-\mathrm{cm}(1-\mathrm{in}$.$) sodium tempera-$ ture decayed to $816^{\circ} \mathrm{C}\left(1500^{\circ} \mathrm{F}\right)$, possibly indicating accumulation of reaction products at that location. Sodium temperatures at 7.5 and $12.7-\mathrm{cm}$ ( 3 and 5 -in.) levels also decayed, leveling at $843^{\circ} \mathrm{C}\left(1550^{\circ} \mathrm{F}\right)$ and the $2.5-\mathrm{cm}(1-\mathrm{in}$.) sodium and concrete temperatures showed a slow approach to this level. 


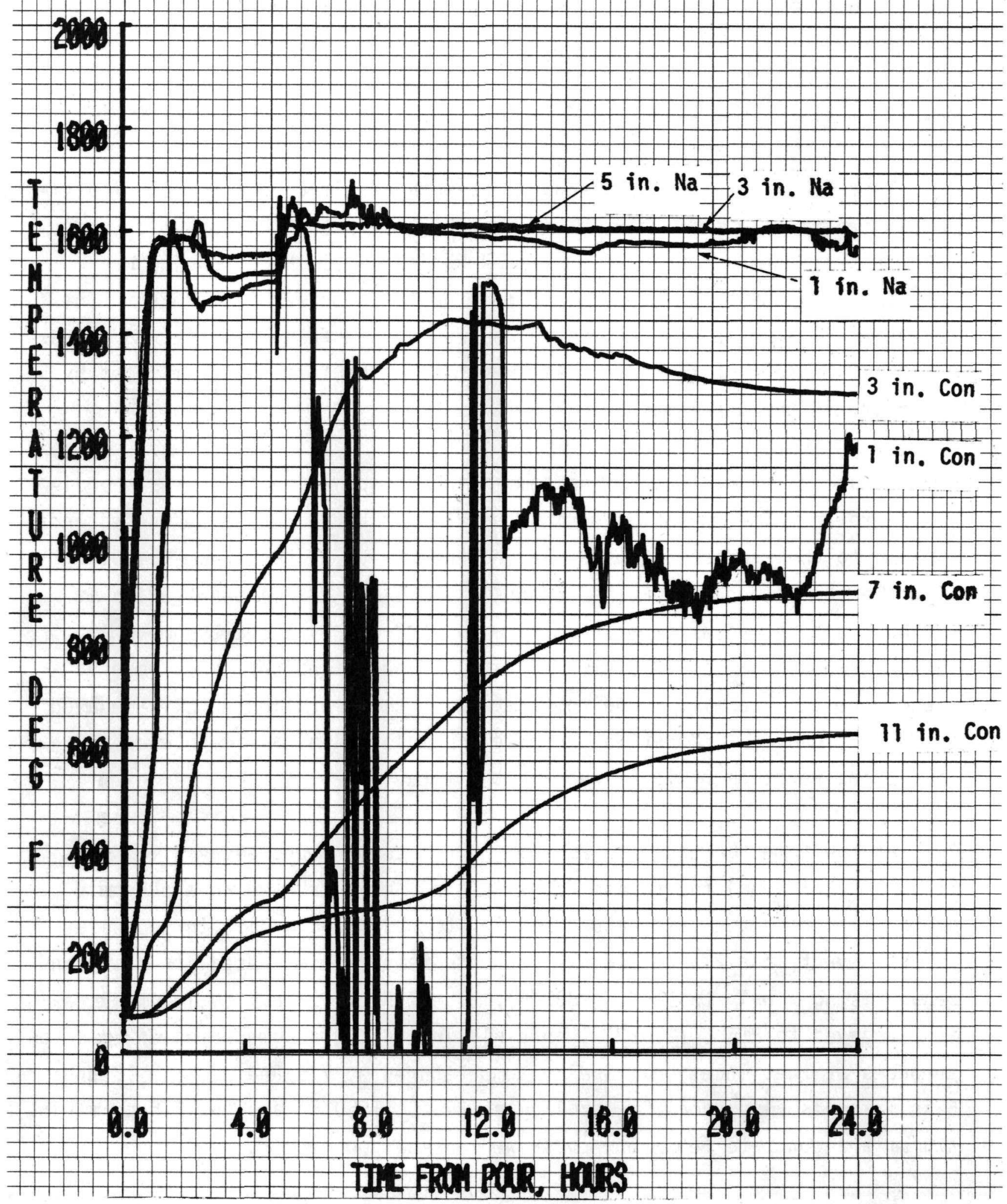

FIGURE 28. SC-17 System Temperatures. 
Five hours into the test, the rest of the sodium inventory was transferred to the test article. All sodium thermocouples responded immediately to the event, as did the $2.5-\mathrm{cm}(1-\mathrm{in}$.$) concrete thermocouple. The 2.5-\mathrm{cm}$ (1-in.) sodium thermocouple showed several peaks substantially $27-55^{\circ} \mathrm{C}$ $\left(50-100^{\circ} \mathrm{F}\right)$ above the mean pool temperatures, indicating observable exotherms over the next three hours. The $2.5-\mathrm{cm} .(1-i n$.$) concrete thermocouple$ failed at six hours into the test. The cause of failure was not determined. The $7.5-\mathrm{cm}(3-\mathrm{in}$.$) concrete thermocouple showed some minor response to$ events noted at the $2.5-\mathrm{cm}(1-\mathrm{in}$.) sodium level. These responses were delayed slightly and may give some indication of the change in thermal diffusivity of the reacted and/or dehydrated concrete. Other concrete thermocouples indicated purely conductive response to the event, with slope changes produced at the characteristic water release temperature range of 93 to $150^{\circ} \mathrm{C}\left(200\right.$ to $\left.300^{\circ} \mathrm{F}\right)$.

Hydrogen concentration and pressure responses (Figure 29) generally followed the events noted from the thermocouple traces; minor hydrogen and pressure increases coincided with the exothermic events noted at two and six hours into the test.

Post-test inspection revealed that the reaction progressed very differently than for SC-15 and 16. No distortion or penetration along the sides was noted. The reaction product layer was very different than that observed for SC-15 and 16. Figure 30 shows a view of the top of the concrete specimen after removing the sodium reservoir. The reaction product separated near the original interface, leaving 5.1 to $7.5 \mathrm{~cm}$ (2 to 3 in.) of residue in the sodium section.

The reaction product contained a large number of voids, looking like sponge. However, the voids were not generally interconnected, so that the material was not pervious. Pieces of aggregate were found in several places throughout the material. The product was hard and brittle, breaking into larger (2.5-cm, 1-in. diameter) pieces. The pieces separated fairly cleanly from the concrete surface. The color of the product was generally a greenish-brown with some darker greys, blacks and tans. 


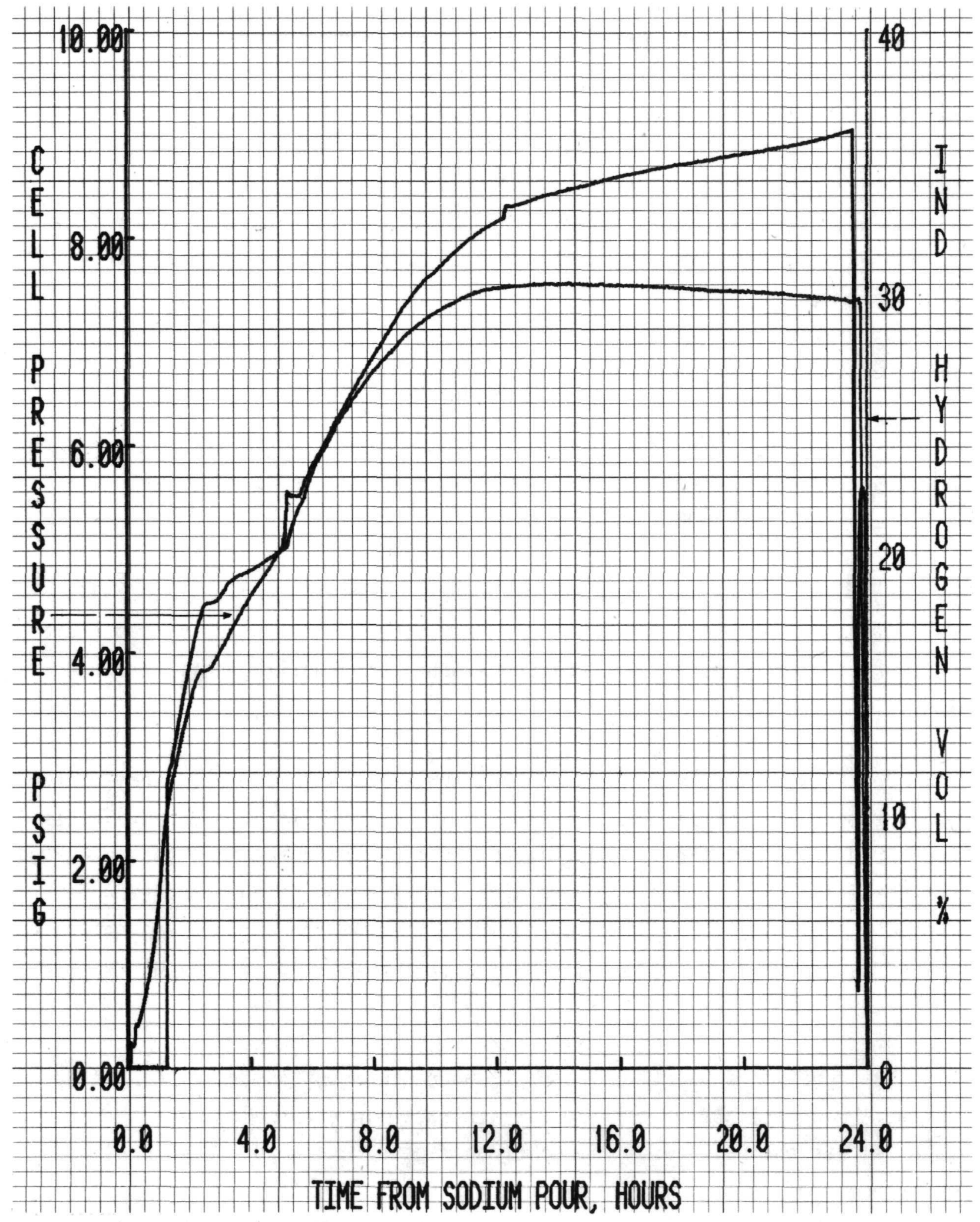

FIGURE 29. SC-17 Cell Pressure and Indicated Hydrogen Concentration. 


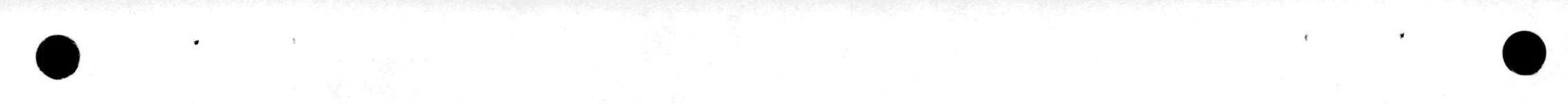

노

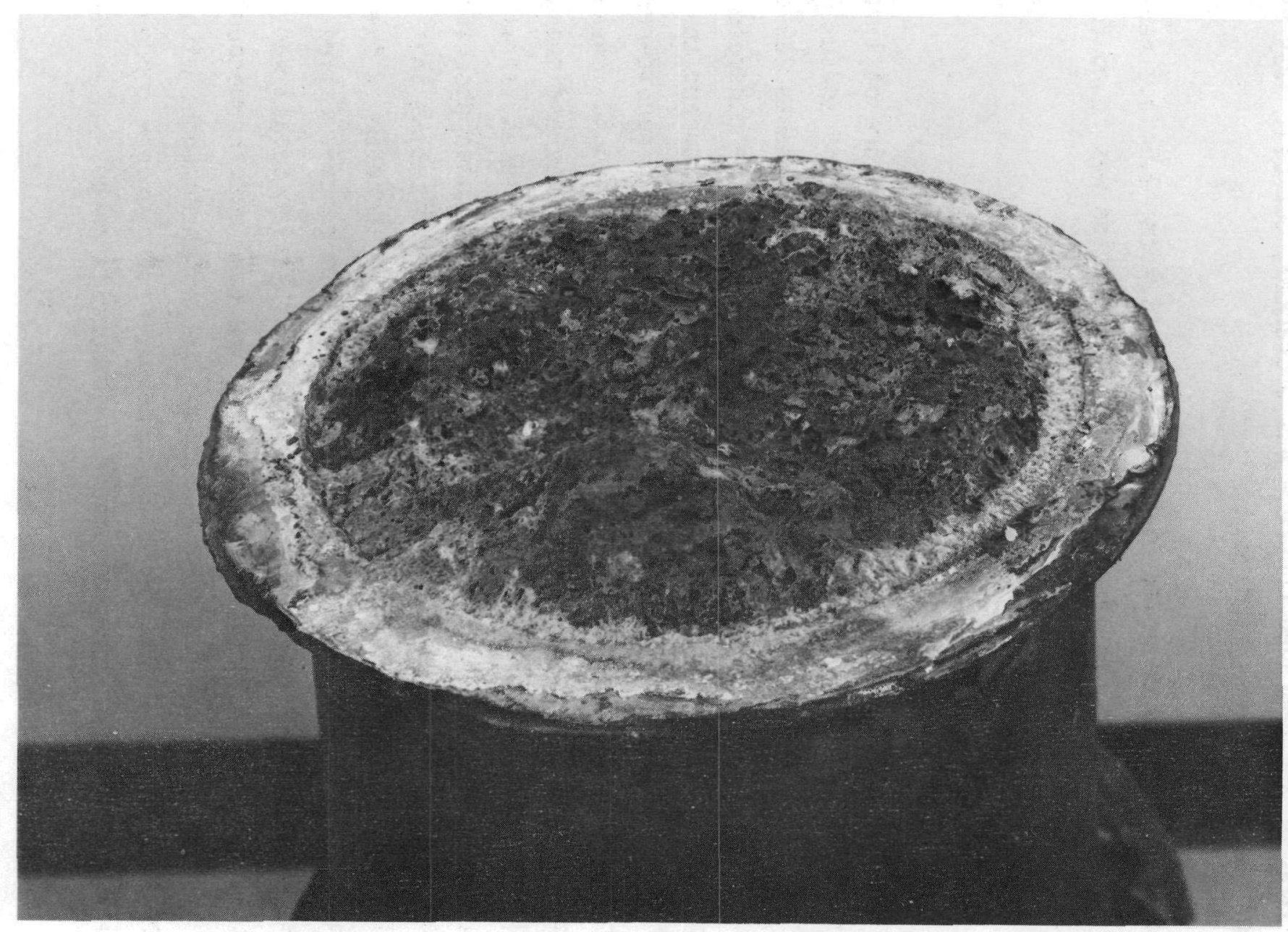

FIGURE 30. Top Surface of Concrete Specimens After Test SC-17. Neg 7802882-13cn 
Figure 31 shows the surface of the test article after removing the cask and some of the reaction product crust. Much of the concrete below the crust, particularly that near the the edges, was very weak, and very heavily cracked. Most of the degraded concrete was uncracked, but fell away from the bulk of the sample when handled.

The penetration was observed to be greatest $(6.4 \mathrm{~cm}, 2.5 \mathrm{in}$.$) near the$ center of the specimen. The average reaction penetration was found to be $5.7 \mathrm{~cm}(2.25 \mathrm{in.})$.

\section{F. TEST DISCUSSION -- TEST SC-18}

Test conditions for test SC-18 included an 8-hour exposure of limestone concrete to $871^{\circ} \mathrm{C}\left(1600^{\circ} \mathrm{F}\right)$ sodium. Initially $3.6 \mathrm{~kg}$ ( $\left.8 \mathrm{lb}\right)$ of sodium hydroxide pellets and $4.5 \mathrm{~kg}(10 \mathrm{lb})$ of limestone concrete chunks $2.5 \mathrm{~cm}$ (1 in.) in diameter were added prior to the sodium pour. The concrete chunks were added to increase the initial surface area of interaction and to make more water available for the initial reaction, in the manner considered to be similar to what would occur due to spalling. This test would investigate, in part, the effects of an early rapid release of water and energy on the overall rate and extent of penetration. Temperature traces, shown in Figure 32, during the first 1 to 2 hours were similar to those observed for test SC-14. Slopes were not significantly different, indicating that the additional surface area did not generate an observable increase in the net energy generated. At two hours into the test a heater circuit failed but was recovered approximately one hour later. No particular detajl was observed fram the sodium thermocouple traces. The concrete thermocouple responses were indicative of a simple heat conduction phenomenon, with no evidence of significant surface erosion. Pressure and hydrogen concentration results were similar, with no significant details noted. (See Figure 33.)

Post-test disassembly showed very limited penetration of the test article surface. All of the chunks were consumed, however. An average 


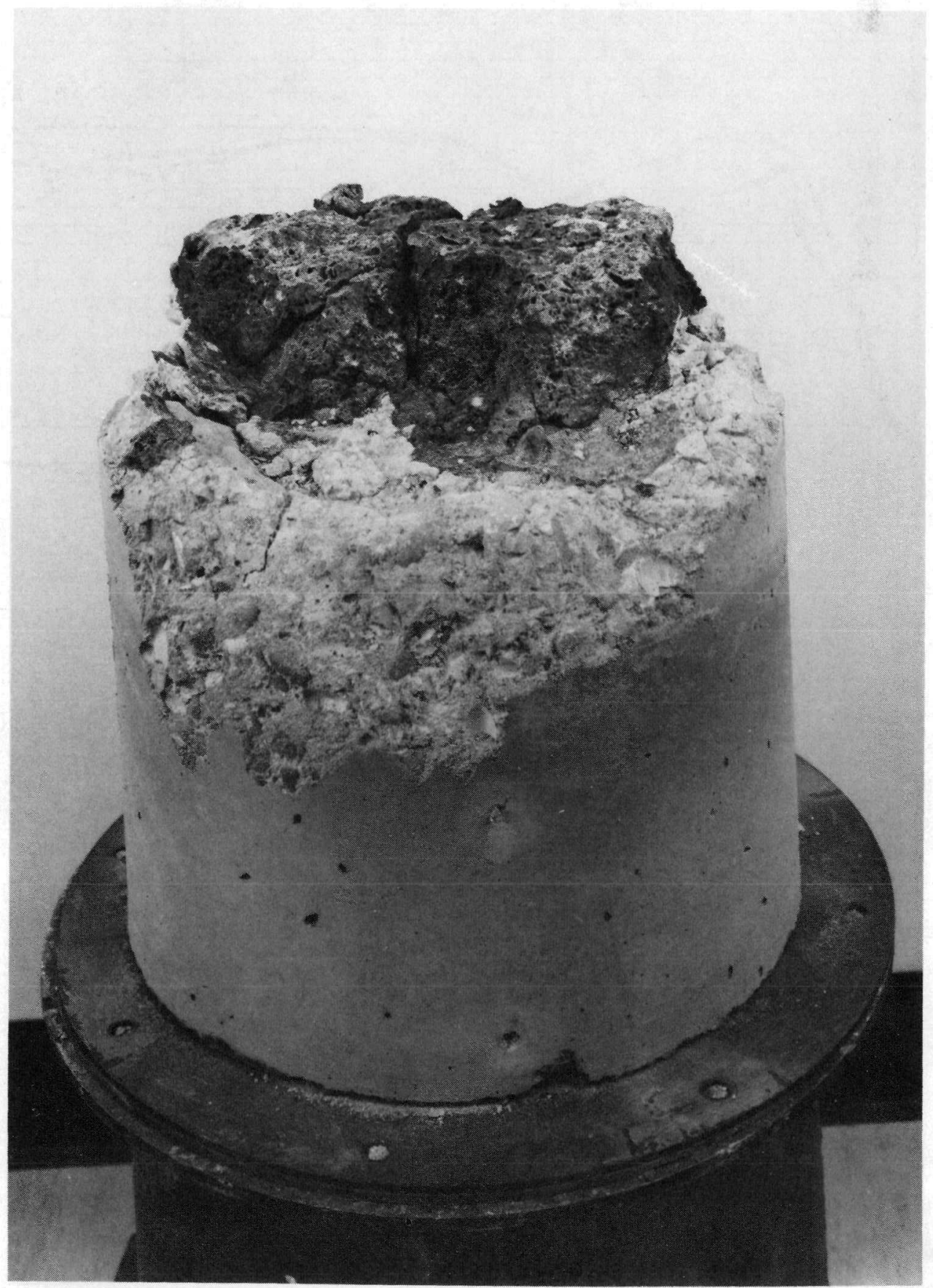

FIGURE 31. Concrete Specimen from Test SC-17 After Partial Inspection. Neg 7802882-1cn 


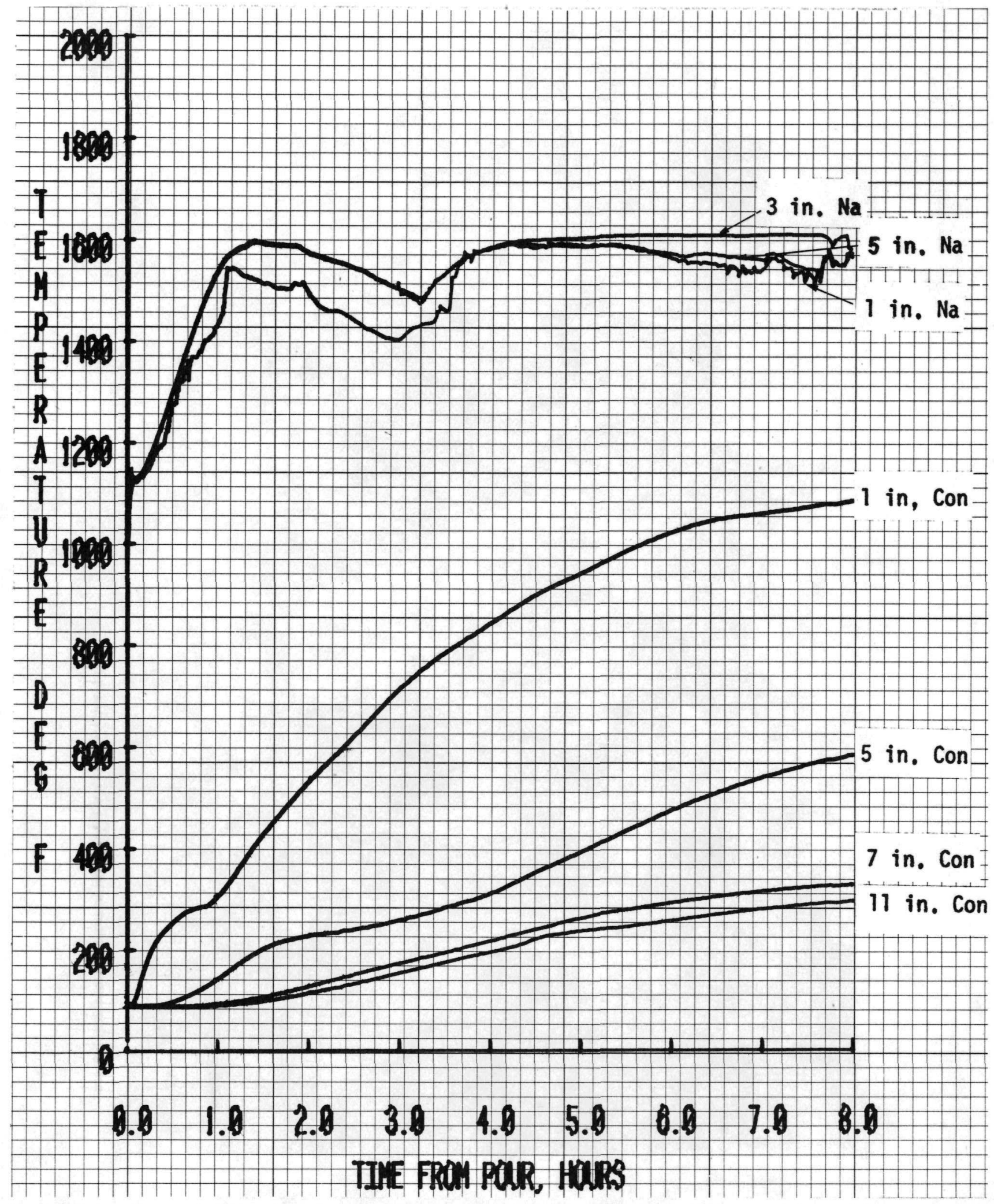

FIGURE 32. SC-18 System Temperatures. 


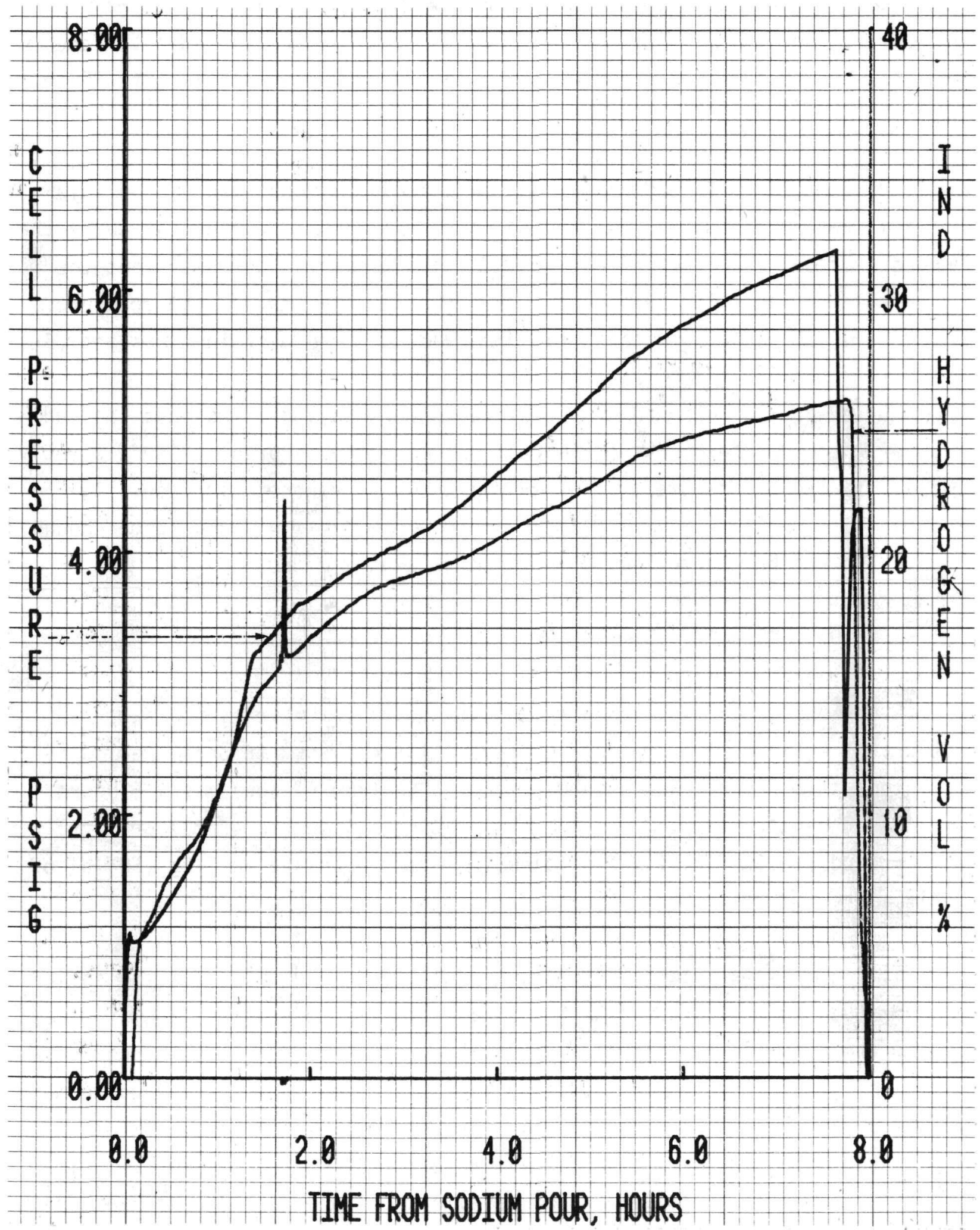

FIGURE 33. SC-18 Cell Pressure and Indicated Hydrogen Concentration. 
penetration over the surface, excluding the erosion of the chunks, was observed to be $2.5 \mathrm{~cm}$ (1 in.). A section of the outside diameter surface near the thermocouple penetrations was locally eroded to a $4.4-\mathrm{cm}(1.75-\mathrm{in}$. depth.

The surface of the concrete was found to be covered with a hard layer varying from approximately 2.5 to $4.6 \mathrm{~cm}$ (1 to 3 in.) in thickness above the eroded surface. This layer had a substantial amount of porosity, but the upper sections appeared less porous than the section nearest the concrete. Figures 34,35 and 36 summarize the observed appearance of the test article.

Review of the data and test article appearance indicates that the addition of the concrete chunks served to produce reaction products sufficiently rapidly to inhibit substantial attack to the base concrete surface. Any additional energy release caused by the increased area was not large enough to be resolved by the methods and equipment used for these tests.

\section{G. TEST DISCUSSION -- TEST SC-19}

Questions concerning sodium hydroxide stability at elevated temperatures $\left(871^{\circ} \mathrm{C}, 1600^{\circ} \mathrm{F}\right)$ prompted a test at a lower system temperature. A limestone test article was subjected to $677^{\circ} \mathrm{C}\left(1250^{\circ} \mathrm{F}\right)$ sodium for 8 hours and then decanted. $3.6 \mathrm{~kg}$ ( $8 \mathrm{lb}$ ) of sodium hydroxide (anhydrous pellets) were included as an initial condition, together with the $22.7 \mathrm{~kg}$ (50 1b) of sodium.

Figure 37 summarizes the temperature histories recorded for the sodium pool and concrete specimen. At 1.5 hours into the test, the 2.5-cm (1-in.) sodium thermocouple began indicating deviations above the average pool temperature. These indications continued for 1-1/2 hours, and then became more erratic. At 2-1/2 hours into the test, when the $2.5-\mathrm{cm}(1-\mathrm{in}$.) sodium thermocouple indicated its local maximum temperature, the 2.5-cm (1-in.) concrete thermocouple showed an increase in the slope of its response curve, indicating possible local penetration to the $2.5-\mathrm{cm}(1-i n$.$) level. Again,$ 


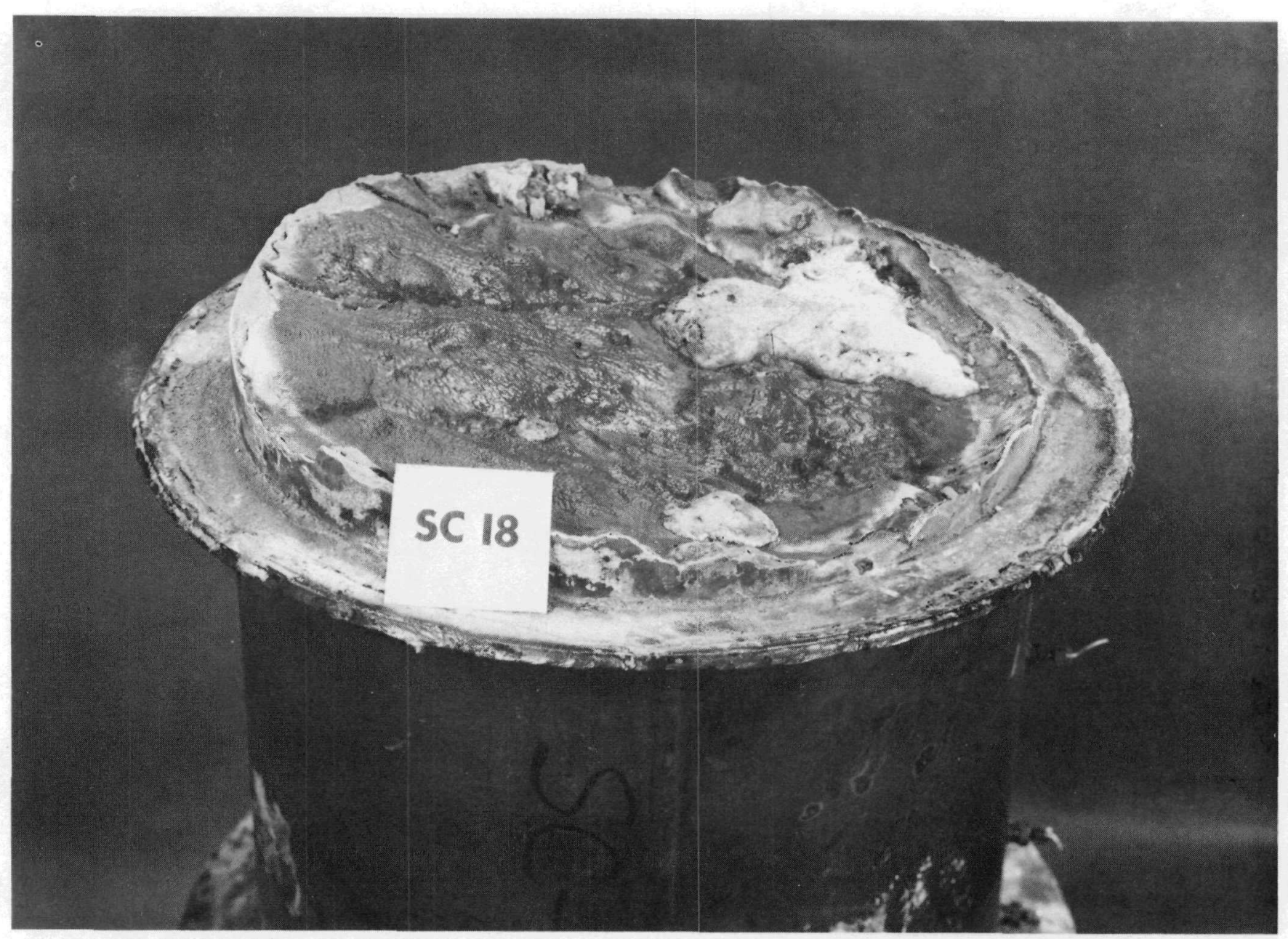

FIGURE 34. Surface of Test SC-18 Concrete Section Following Test. Neg $7803251-7 \mathrm{cn}$ 


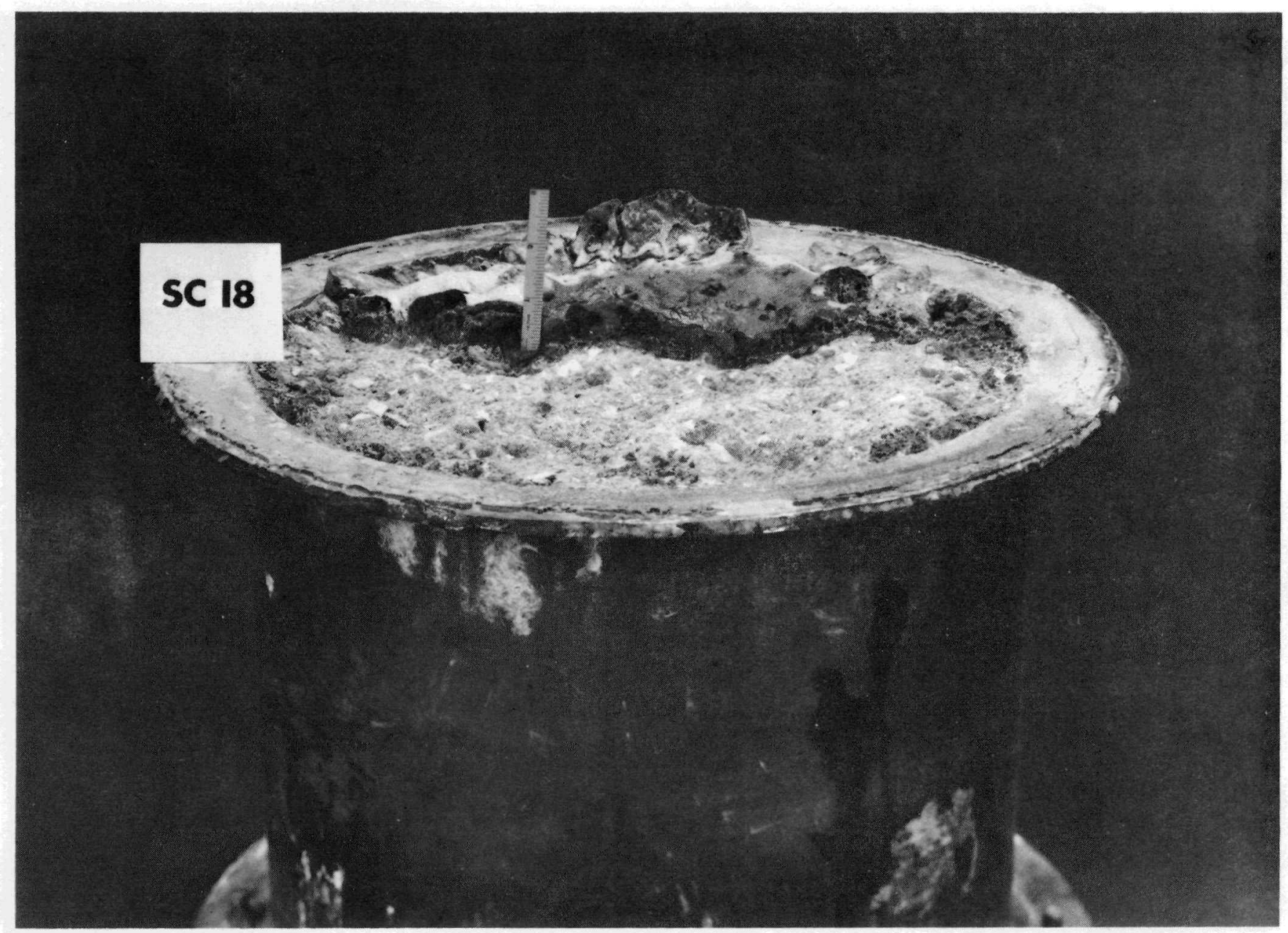

FIGURE 35. Concrete Specimen After Removal of a Portion of the Reaction Product Crust.

Neg 7803257-13cn 


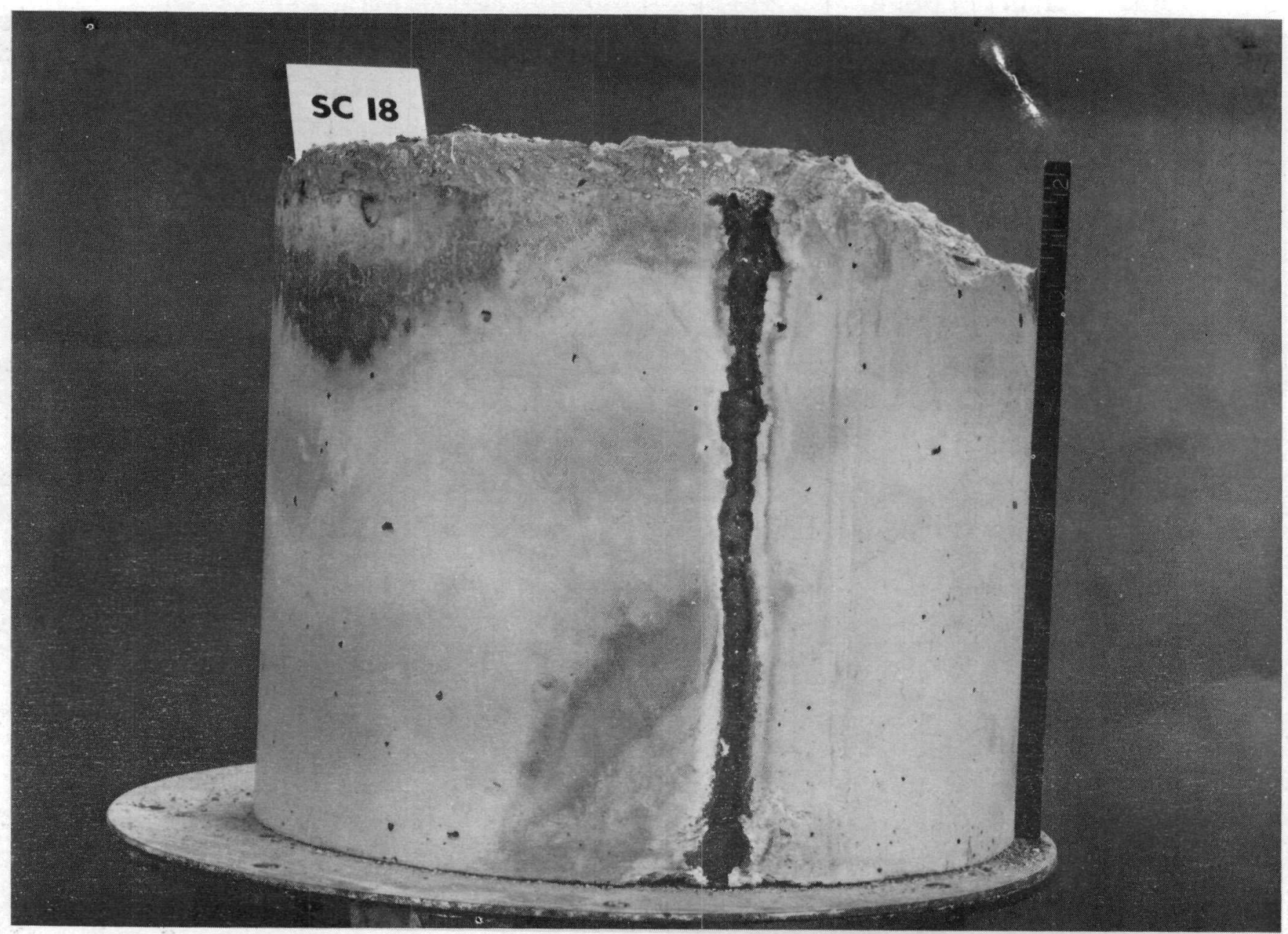

FIGURE 36. Penetration Depths Following Test SC-18. 


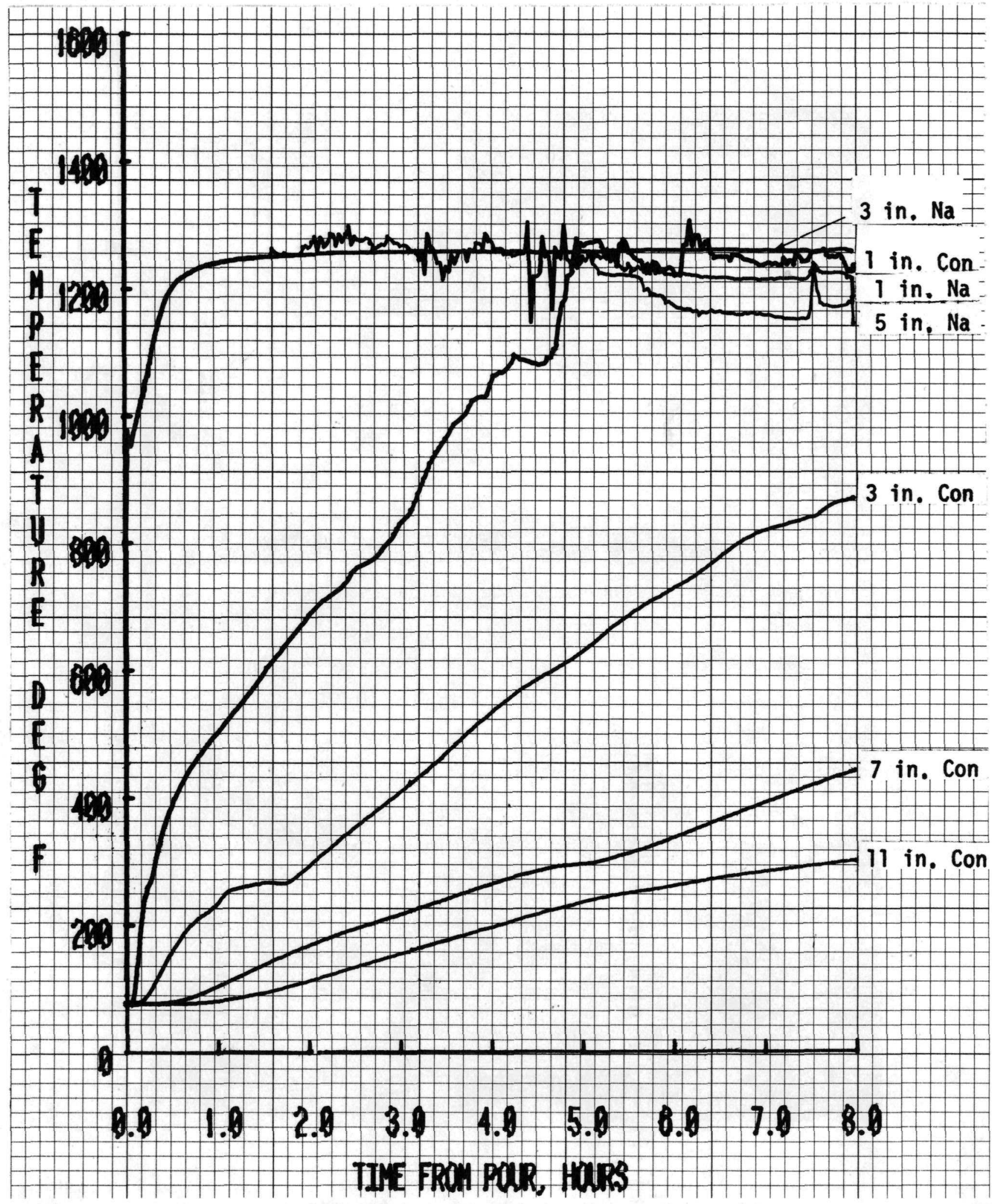

FIGURE 37. SC-19 System Temperatures. 
at four hours into the test, the temperature levels at the $2.5-\mathrm{cm}(1-\mathrm{in}$. sodium and concrete thermocouples showed correlated responses. At 4-1/2 hours into the test, the $2.5-\mathrm{cm}(1-i n$.$) sodium thermocouple showed a very$ sharp erratic response, accompanied by a temperature decrease at the $2.5-\mathrm{cm}$ (1-in.) concrete level; th is was followed shortly thereafter by a very rapid increase of $2.5-\mathrm{cm}(1-i n$.$) concrete temperature to mean sodium temperatures$ at five hours, after which the $2.5-\mathrm{cm}(1-i n$.$) concrete temperature was gen-$ erally above that at the $2.5-\mathrm{cm}(1-\mathrm{in}$.) sodium level. At that time, the 12.7 -cm (5-in.) sodium thermocouple showed a decreasing temperature trace, the cause of which was not determined. The sheathed, 7.6-cm (3-in.) sodium thermocouple showed almost no detail during the test.

Other thermocouples at the $7.6,17.8$ and $27.9-\mathrm{cm}(3,7$, and 11-in.) concrete levels showed generally smooth heat conduction responses to the transients occurring at the interface. Hydrogen and pressure responses (Figure 38) were also quite smooth, with little detail noticed.

Post-test inspection showed that most of the reaction products were decanted from the concrete suface, as seen in Figure 39. A crust was observed adhering to the concrete surface. This crust was found to be very rich in sodium hydroxide and varied between 0.3 and $2.5-\mathrm{cm}(1 / 8$ and 1 in.) in thickness but was generally between 3 and $6 \mathrm{~mm}(1 / 8$ and $1 / 4 \mathrm{in}$.). Figure 40 shows the concrete specimen after the crust and cask had been removed. As $c$ an be seen in the photo, the penetration is generally minimum along the edge and greater near the center of the specimen, similar to the penetration characteristics noted for test SC-14. Average and maximum penetrations were observed to be 3.8 and $5.7 \mathrm{~cm}$ (1.5 and $2.25 \mathrm{in.})$ respectively.

\section{H. TEST DISCUSSION -- SC-20}

Test SC-20 parameters included a basalt specimen, $510^{\circ} \mathrm{C}\left(950^{\circ} \mathrm{F}\right)$ sodium temperatures and an 8-hour test duration. $3.6 \mathrm{~kg}(8 \mathrm{lb})$ of sodium hydroxide was placed on the concrete surface prior to the sodium pour. The 


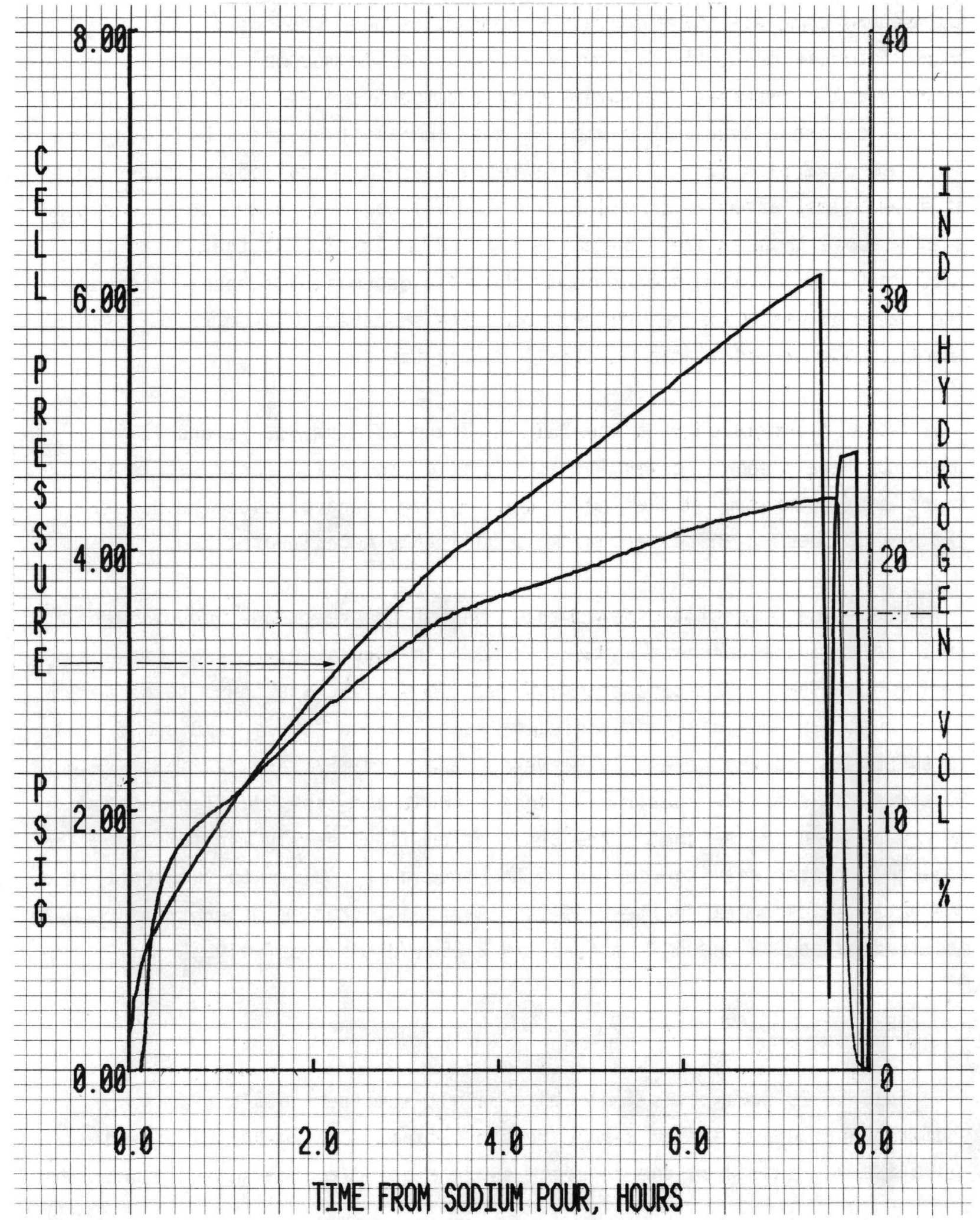

FIGURE 38. SC-19 Cell Pressure and Indicated Hydrogen Concentration. 


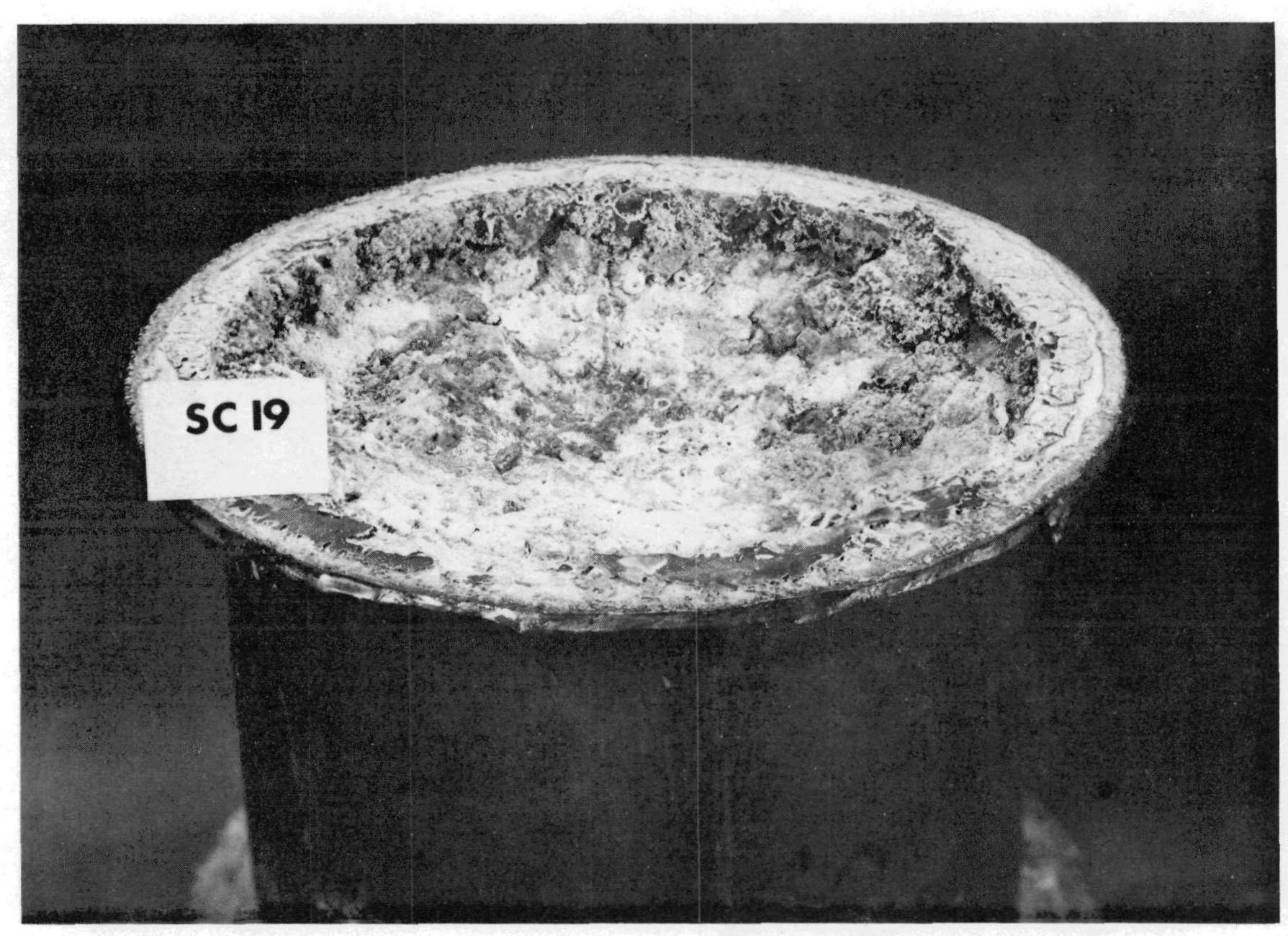

FIGURE 39. Surface of Test SC-19 Concrete Specimen Following Test. Neg 7803251-3cn 


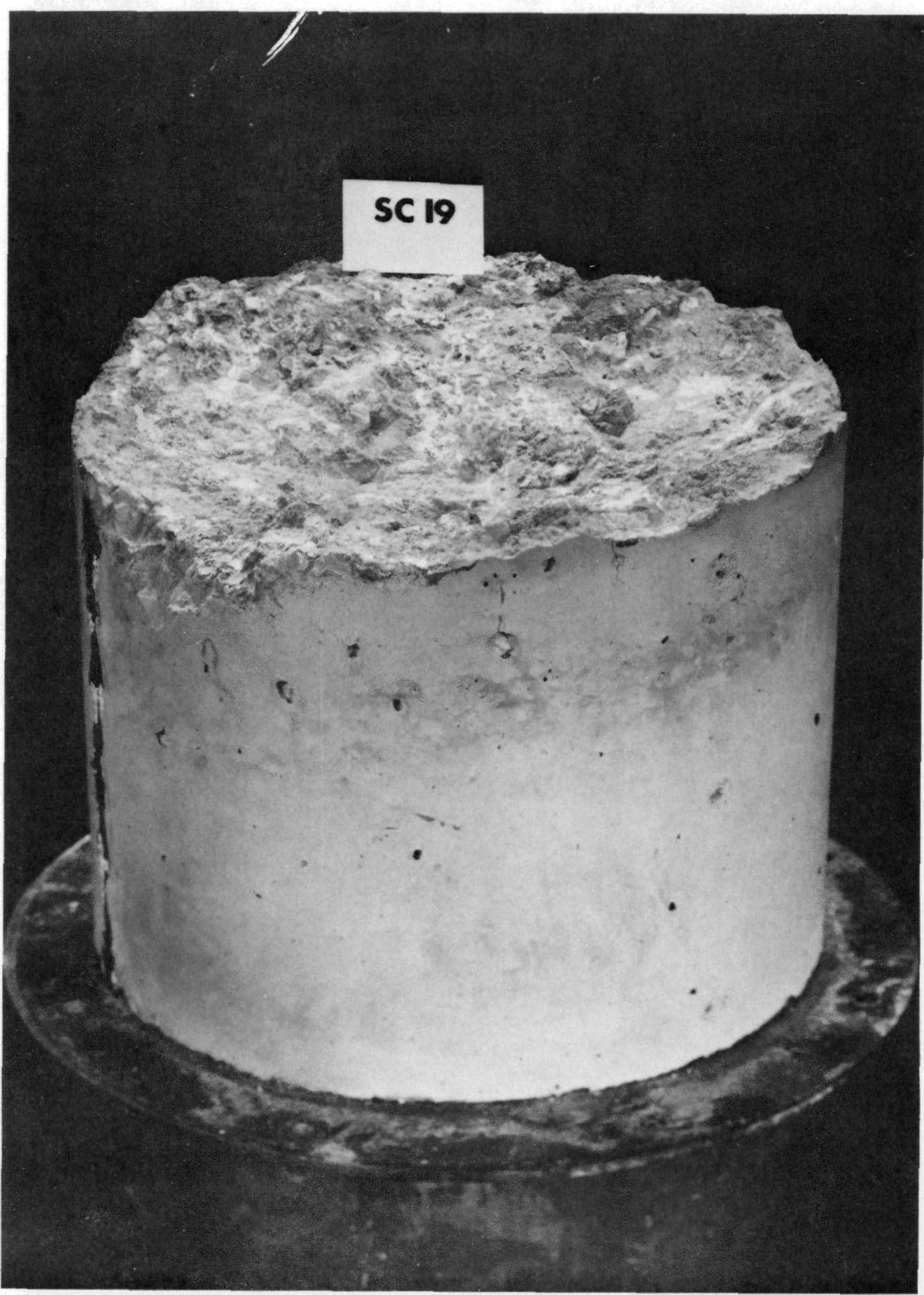

FIGURE 40. Concrete from Test SC-19 After Inspection.

Neg 7803251-1cn 
test was intended to provide further data relevant to the effects of low temperature on overa 11 reaction rates and penetration extents.

During the test, no significant abnormal response was noted from the thermocouple, save the test insulation $T / C$ which indicated a broken thermocouple response. The sodium thermocouples tracked the thermal transient during the pour and re-heat portions of the test. Reheat took 45 minutes to increase sodium temperatures from the minimum at $404^{\circ} \mathrm{C}\left(760^{\circ} \mathrm{F}\right)$ to the test temperature of $510^{\circ} \mathrm{C}\left(950^{\circ} \mathrm{F}\right)$. Sodium pool temperatures remained close to the target temperature during the rest of the test. One minor $\left(11^{\circ} \mathrm{C} 20^{\circ} \mathrm{F}\right)$ long-time constant temperature increase was noted at four hours into the test; the cause was not determined. Both hydrogen concentration and pressure indicated increases in response to the increased temperature level.

Concrete thermocouple responses were very smooth. A decrease in the rate of temperature rise was observed as the local temperature passed through the water release range from 98 to $120^{\circ} \mathrm{C}\left(200\right.$ to $\left.250^{\circ} \mathrm{F}\right)$. The rest of the response curves were very conduction-like.

The rest of the recorded data was similarly well-behaved, without any noticeable detail, or observable deviations from a smooth response. Figures 41 and 42 summarize the principal temperature, hydrogen, and pressure responses recorded during the test.

Post-test inspection revealed a hard hydroscopic crust on top of the concrete surface. Figure 43 shows the surface appearance after the sodium reservoir was removed. The crust was found to extend from approximately 6 to $13 \mathrm{~mm}$ ( $1 / 4$ to $1 / 2 \mathrm{in.})$ above the original concrete surface. The crust appeared to be composed principally of sodium hydroxide. The cask was removed from the concrete specimen and cracks were observed several inches below the surface, as seen in Figure 44. The sodium or sodium hydroxide was observed to have penetrated along the cask wall $2.5 \mathrm{~cm}$ ( 1 in.) deep and at one location to a $5.1-\mathrm{cm}(2-$ in.) depth. However, the extent of radial erosion or attack was less than $1.5 \mathrm{~mm}(1 / 16-i n$.$) .$ 


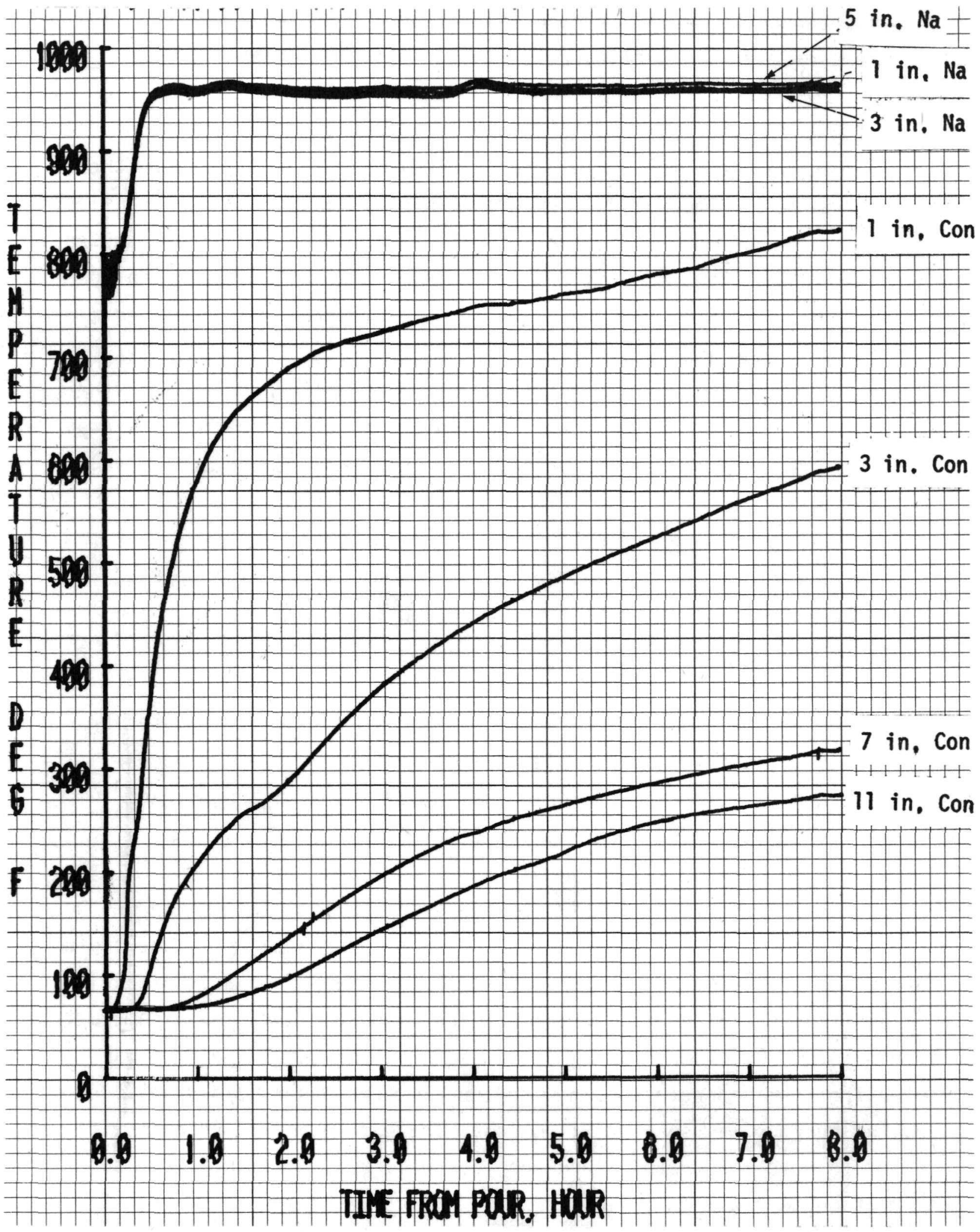

FIGURE 41. SC-20 System Temperatures. 


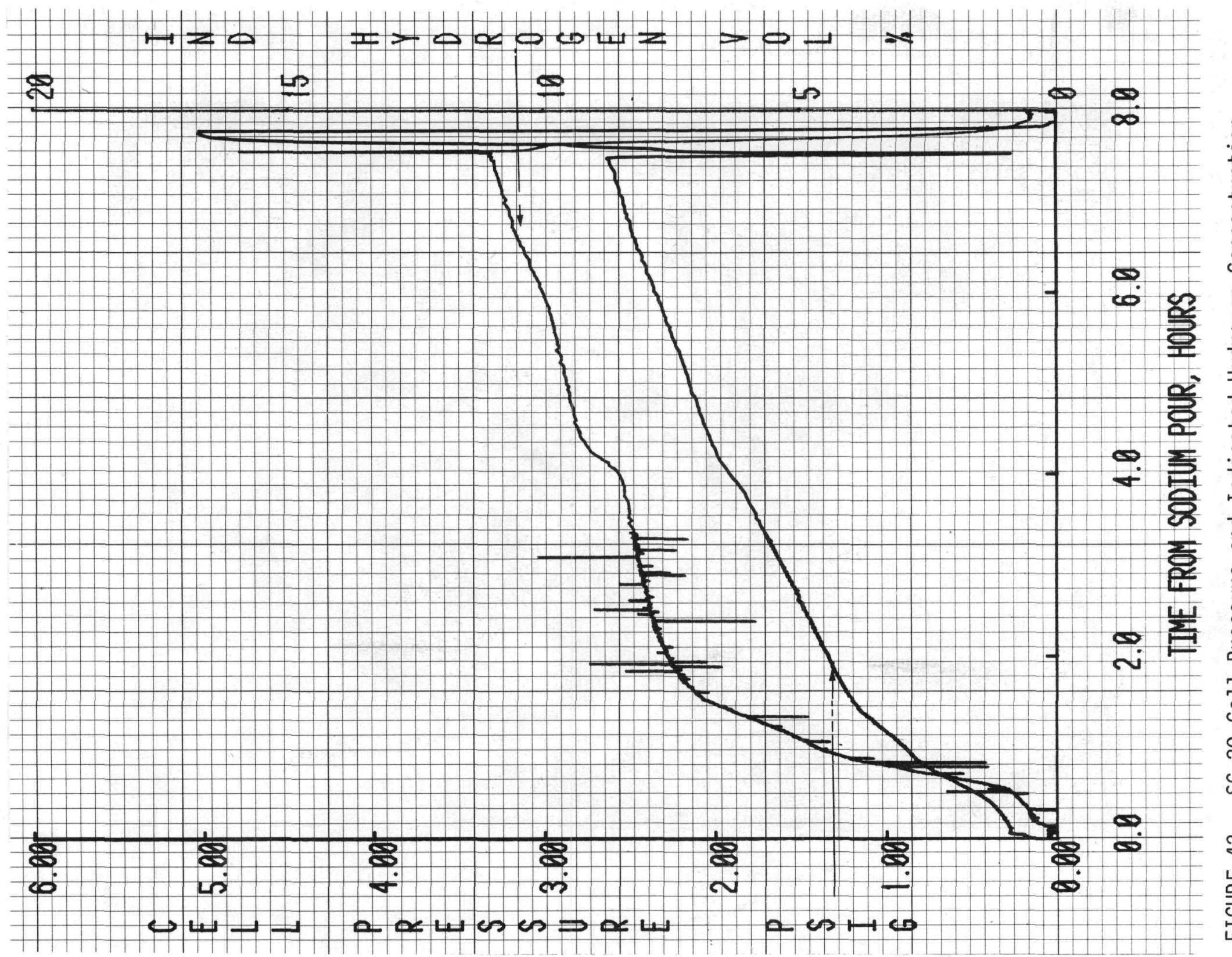




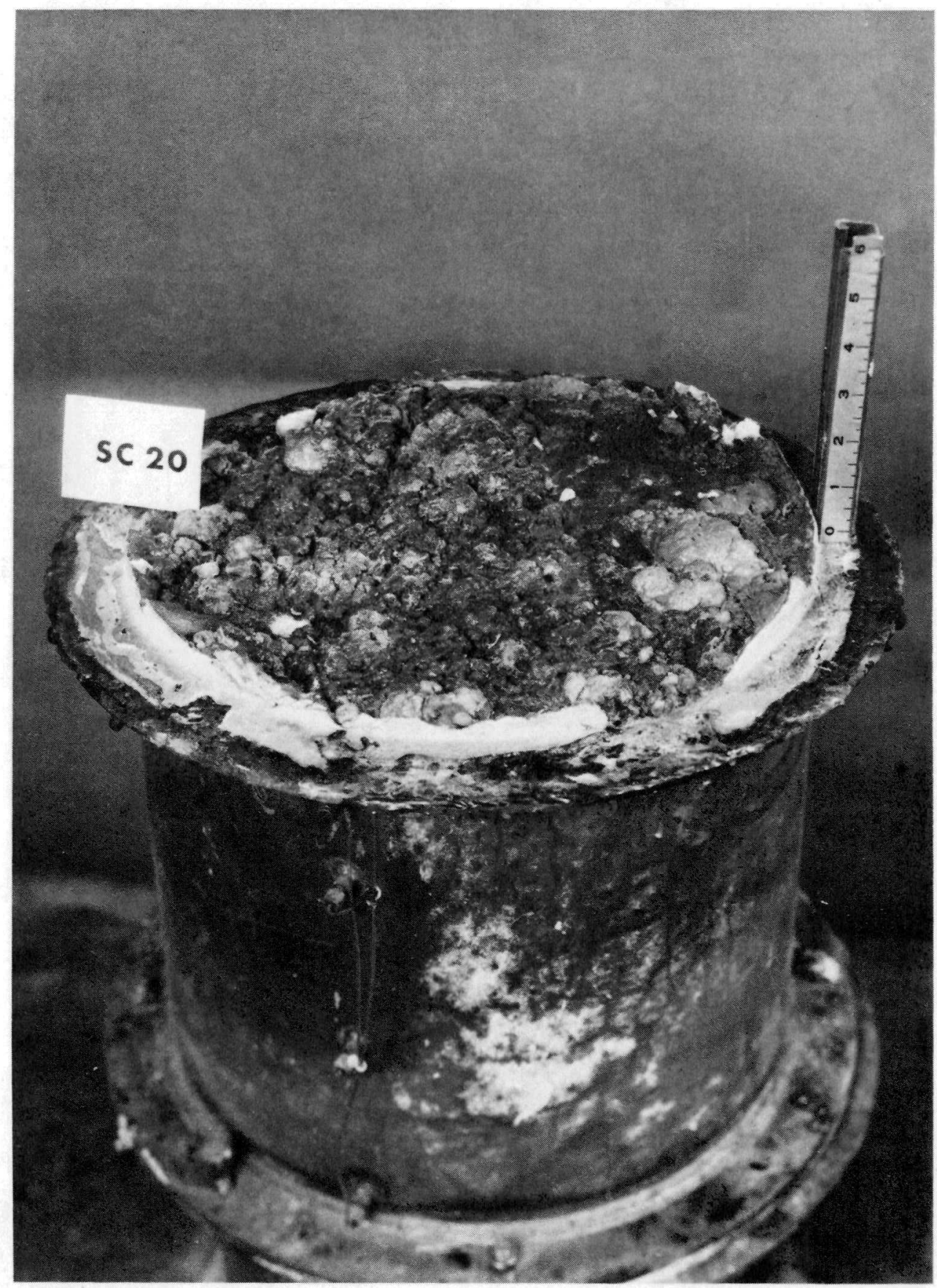

FIGURE 43. Surface of Test SC-20 Concrete Section After Test.

Neg 7804306-28cn 


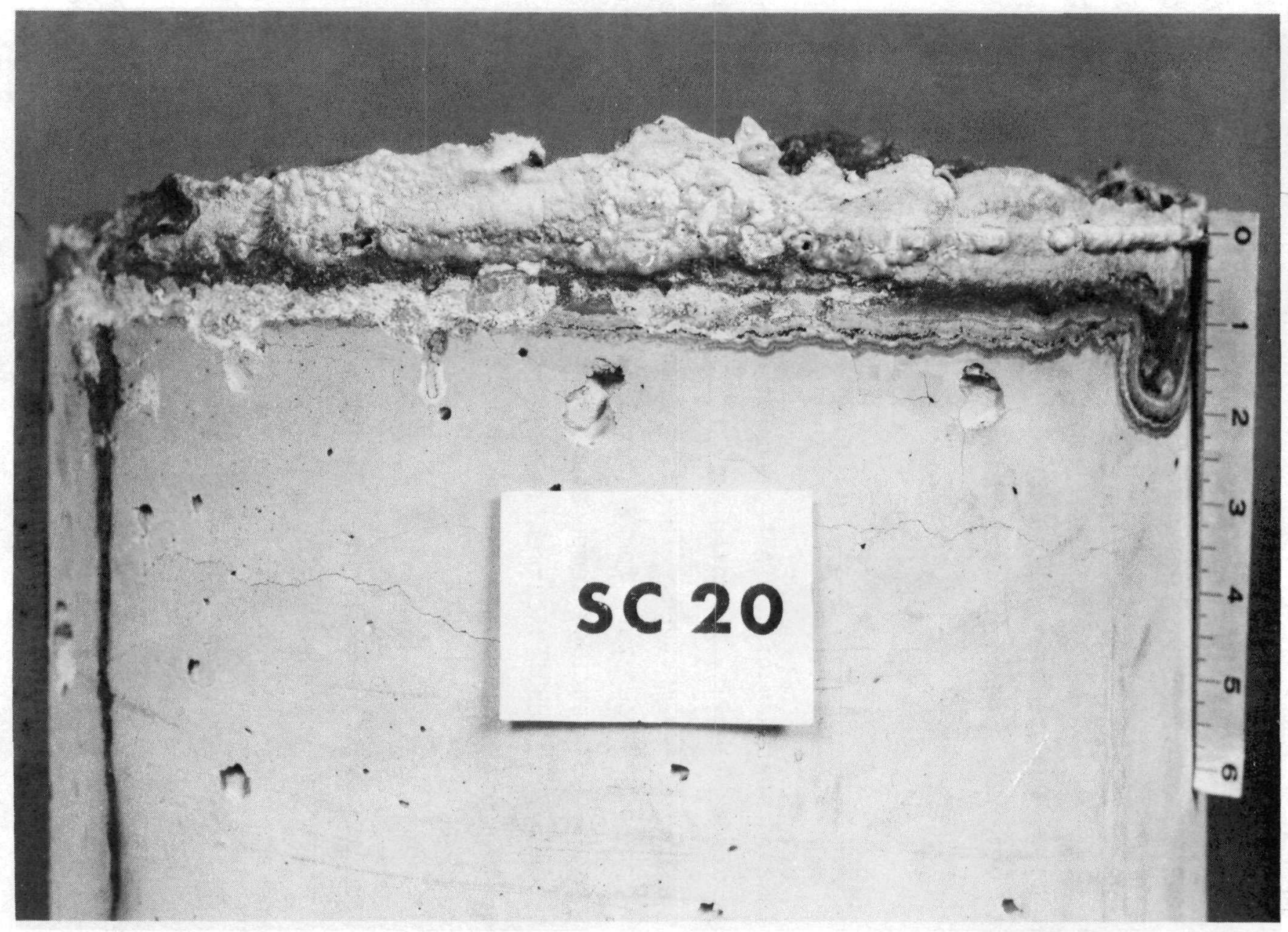

FIGURE 44. Side View of Test SC-20 Concrete Test Section After Removal of Cask. Neg 7804306-2cn 
The surface layer adhered very tenaciously to the concrete surface, and in order to observe the interface, the concrete specimen was broken intentionally in several steps. Figure 45 shows the interface and concrete after the first piece was broken and removed. The rulers' "0" marks were aligned with the original concrete surface. The extent of the reaction penetration was less than $6 \mathrm{~mm}(1 / 4 \mathrm{in}$.$) . Ignoring the very local penetration between$ the concrete and the cask wall, no penetration was noted deeper than $6 \mathrm{~mm}$ (1/4 in.). Several cracks were noted, as seen in the photograph. Little discoloration of the specimen was observed. The concrete appeared to retain most of its original strengh, as determined by the effort required to break it for inspection.

\section{TEST DISCUSSION -- TEST SC-21}

Continued discussion of the effects of temperature and related sodium hydride/hydroxide stability prompted a test identical to test SC-20 in all respects except for temperature. The test temperature was held at the $677^{\circ} \mathrm{C}\left(1250^{\circ} \mathrm{F}\right)$ pour temperature for 8 hours. This test was expected to bound any "threshold" reaction temperature (between the $510^{\circ} \mathrm{C}\left(950^{\circ} \mathrm{F}\right)$ previous test and $677^{\circ} \mathrm{C}\left(1250^{\circ} \mathrm{F}\right)$ current test) and enable a direct comparison to be made between basalt and limestone (test SC-19) under identical conditions.

The pour at the start of the test went smoothly. The 2.5-cm (1-in.) sodium thermocouple responded in the usual manner, but did not maintain the target temperature for more than a few minutes. The $7.6-\mathrm{cm}(3-\mathrm{in}$.) thermocouple was protected by a 6-mm (1/4-in.) SS sheath, and showed a very smooth response in the region of $677^{\circ} \mathrm{C}\left(1250^{\circ} \mathrm{F}\right)$ for the entire test. The thermocouple at the 12.7-cm (5-in.) level showed erratic response, with temperatures generally well below $649^{\circ} \mathrm{C}\left(1200^{\circ} \mathrm{F}\right)$. Post-test inspection showed the 12.7-cm (5-in.) thermocouple to have failed, and inspection of the data suggests that failure occurred shortly after the pour, such that data recorded on this channel is suspect. The behavior of the $2.5-\mathrm{cm}(1-\mathrm{in}$. level thermocouple showed a somewhat more detailed steady response, perhaps 


\section{•}

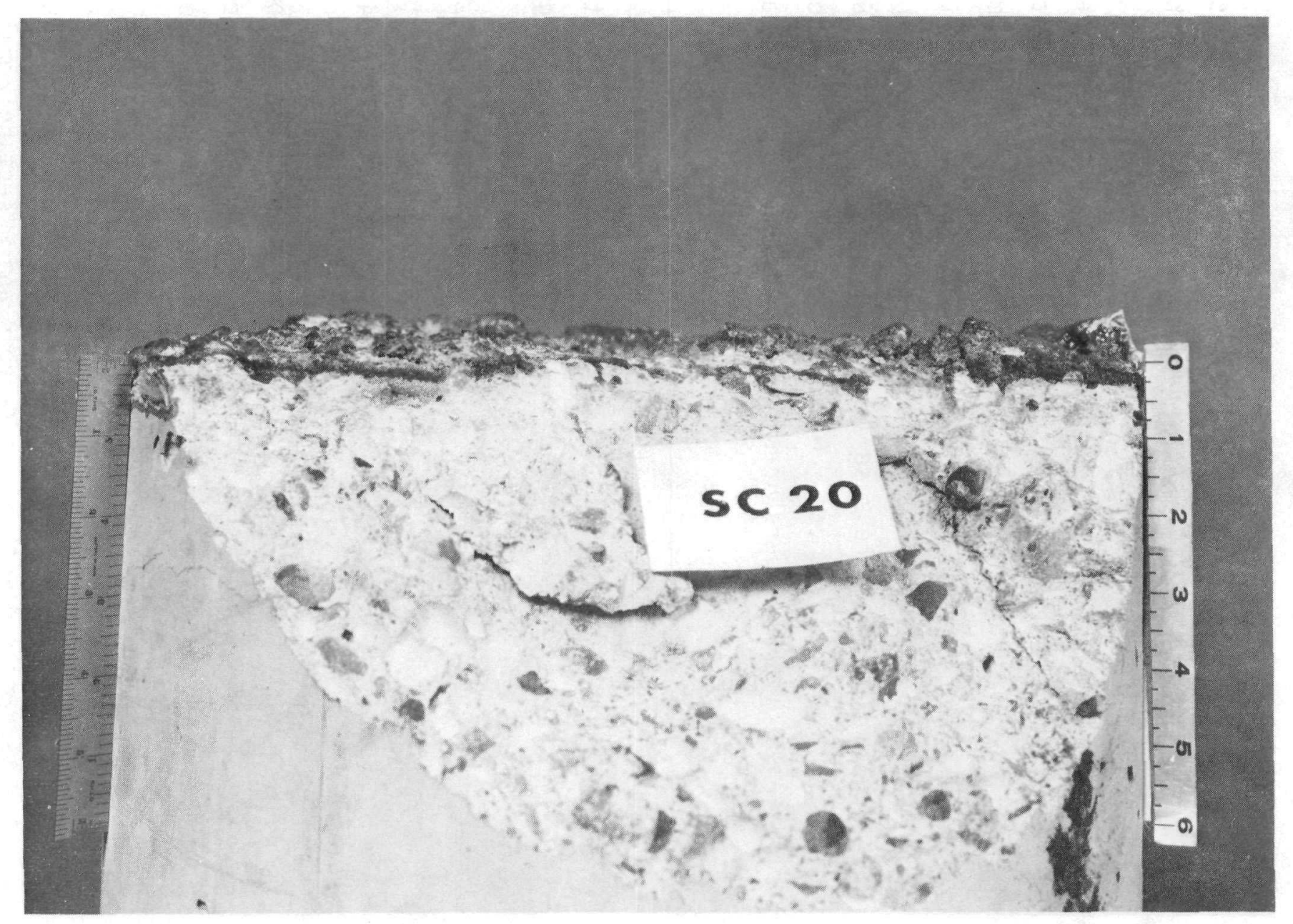

FIGURE 45. Partial Section View of Concrete Specimen from Test SC-20. 
indicating that the junction was located, or reformed, in a region partially thermally isolated from active chemical reactions.

The thermocouple at the 2.5-cm (1-in.) concrete level showed a usual heat conduction response for approximately two hours, at which time the response became more erratic. Substantial increases in the indicated temperature were noted at four and six hours into the test. The increase noted at six hours drove temperatures above the poo 1 temperature indicated by the $7.6-\mathrm{cm}(3-i n$.$) sodium thermocouple, indicating that an exothermic$ reaction was taking place. The thermocouples at the $7.6,17.8$ and $27.9-\mathrm{cm}$ (3, 7 and 11-in.) locations showed smooth heat conduction reponses, which reflected isotherms due to water release in the vicinity of 93 and $316^{\circ} \mathrm{C}$ $\left(200\right.$ and $600^{\circ} \mathrm{F}$ ) as generally observed. Other system temperatures recorded showed no notable features. Temperatures measurements noted are summarized in Figure 46 .

Both hydrogen concentration and cell pressure curves were very smooth. Both reflected the exponential approach to a near-asymptotic value noted for previous tests. There were no discontinuities or changes in slope suggesting responses to events indicated by the sodium or the $2.5-\mathrm{cm}(1-\mathrm{in}$.$) con-$ crete thermocouples. This suggests that any events indicated by these thermocouple data were local in nature and of insufficient energy content to affect overall system response. These data are summarized in Figure 47.

Post-test inspection revealed a hard convoluted mass in the bottom of the sodium reservoir section. The $12.7-\mathrm{cm}(5-\mathrm{in}$.) sodium thermocouple was observed to have been completely severed at the approximate location of the initial sodium level. The $2.5-\mathrm{cm}$ (1-in.) thermocouple was damaged during removal procedures and no assessment of its condition was made. The 7.6-cm (3-in.) sheathed thermocouple appeared to be unharmed. A section of the reaction product mass remained with the reservoir and a section remained with the concrete when the test article was disassembled, as shown in Figures 48 and 49. 


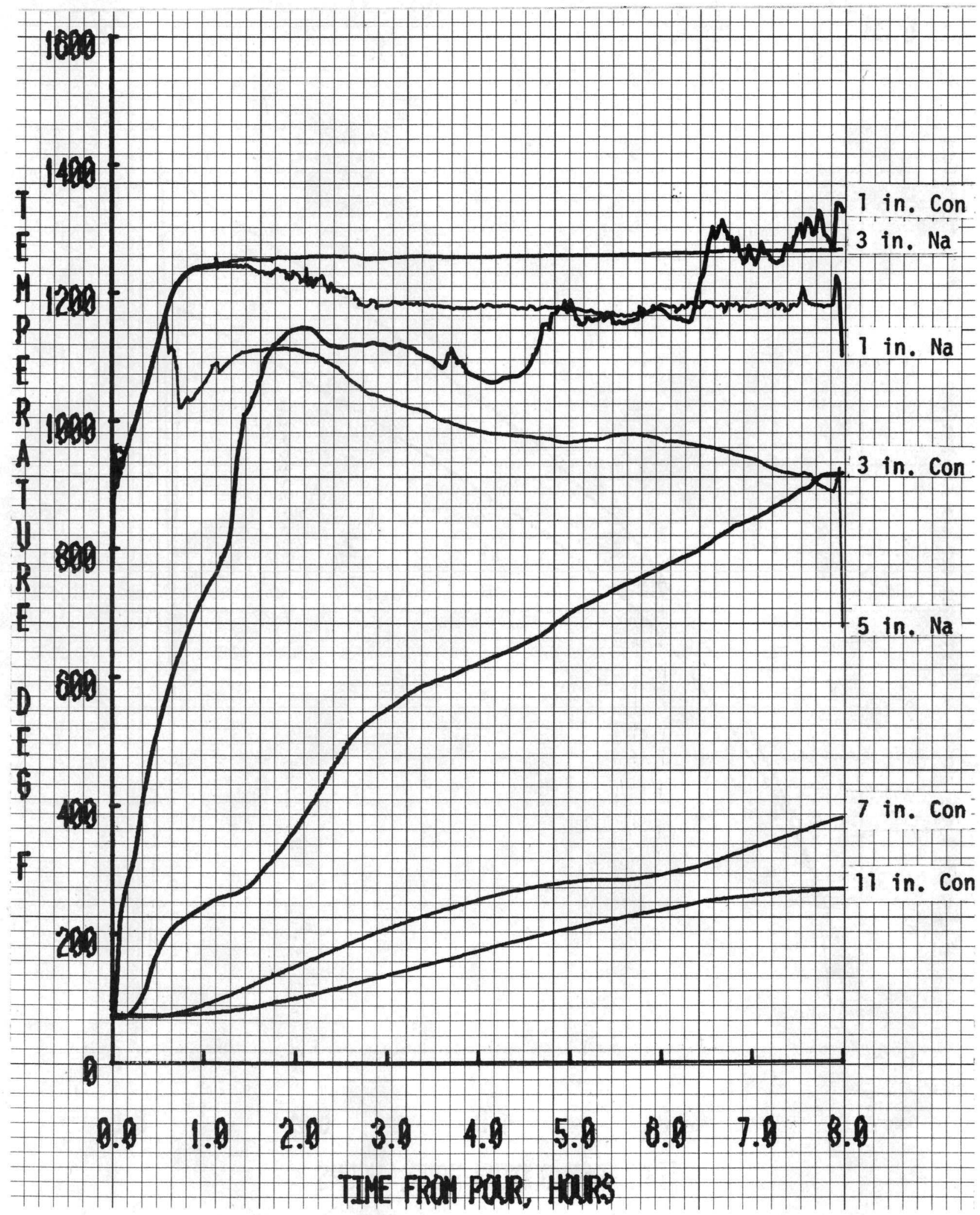

FIGURE 46. SC-21 System Temperatures. 


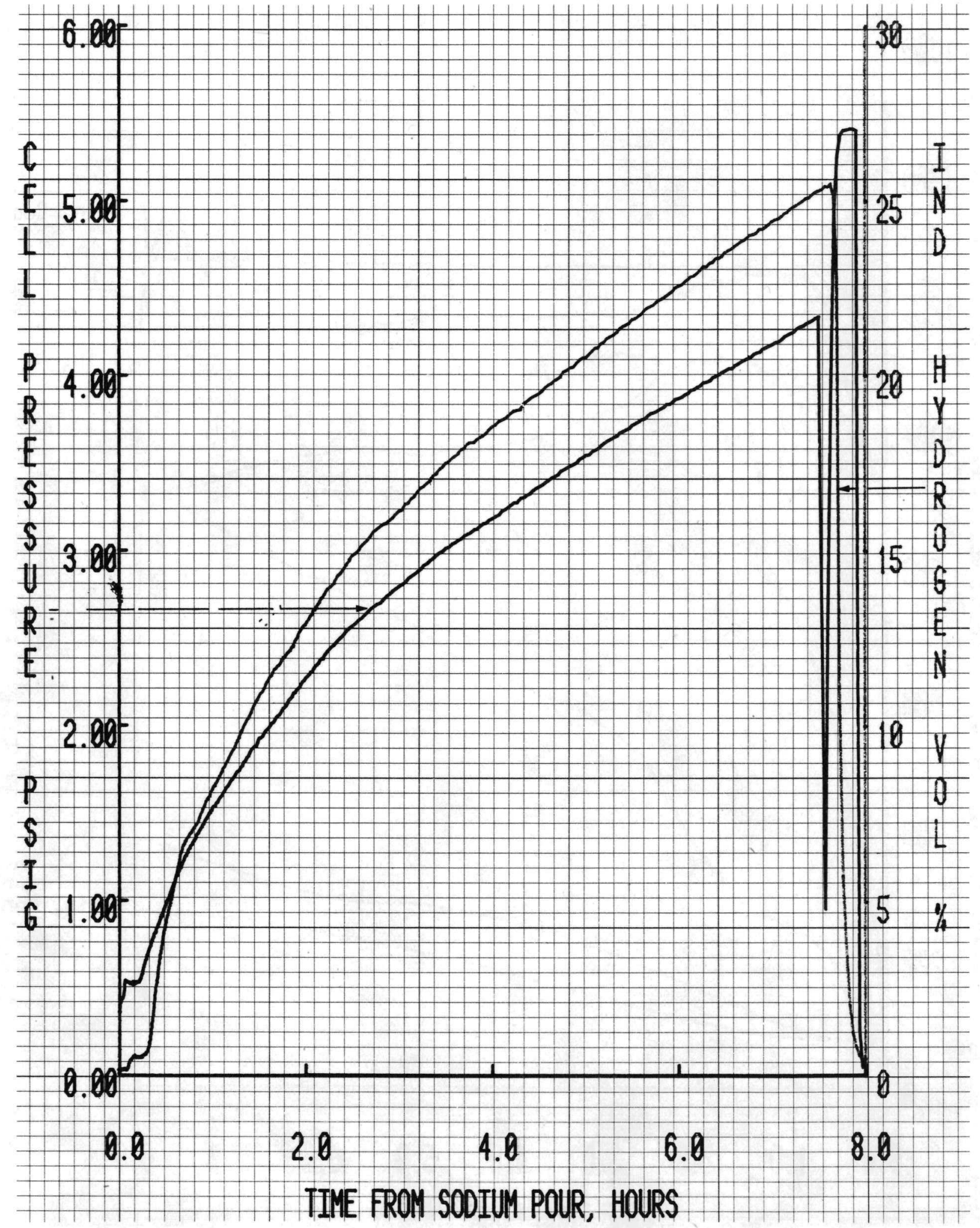

FIGURE 47. SC-21 Cell Pressure and Indicated Hydrogen Concentration. 


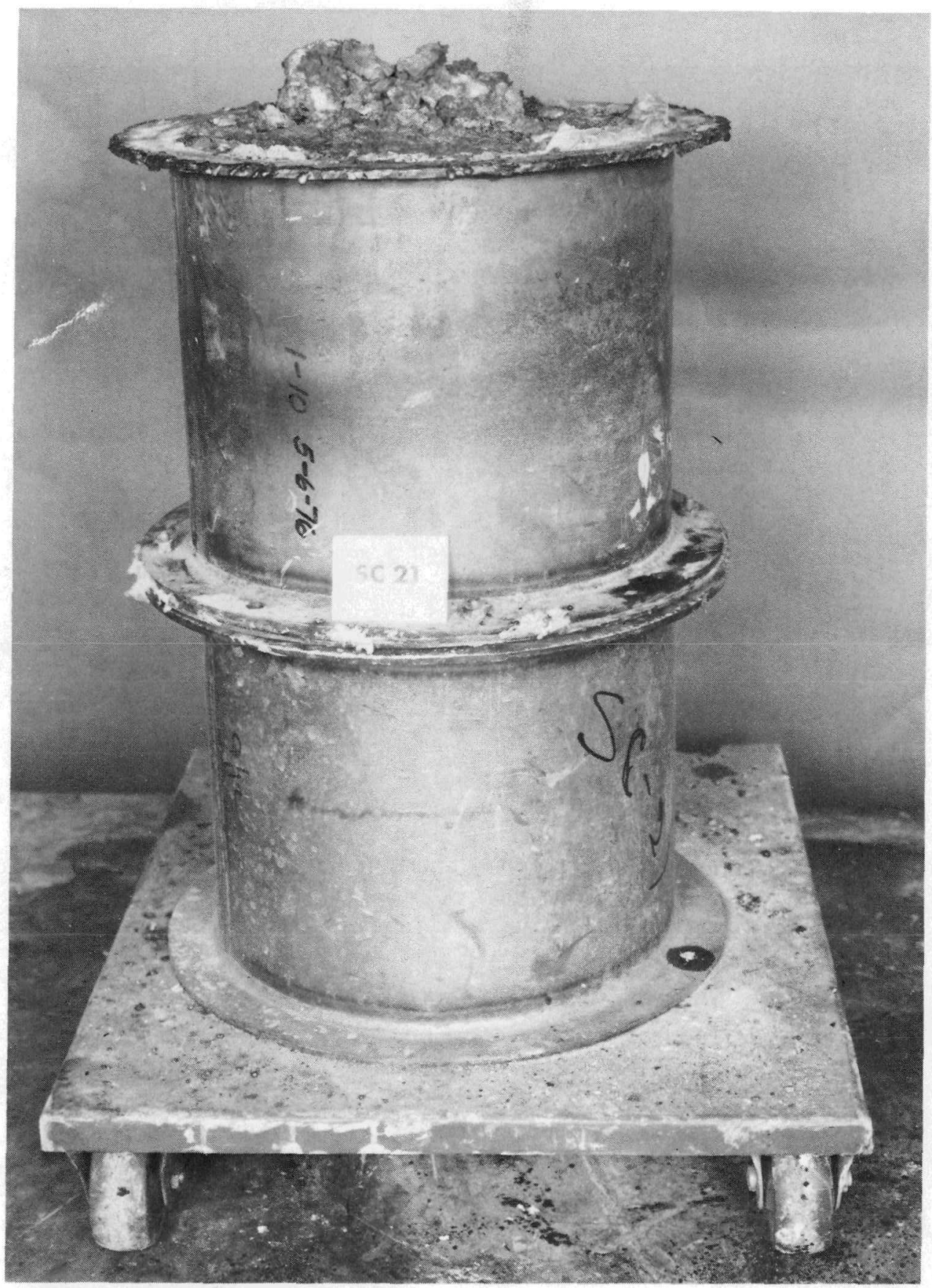

FIGURE 48. SC-21 Test Article After Removal of Sodium Section. Neg 7804306-16cn 


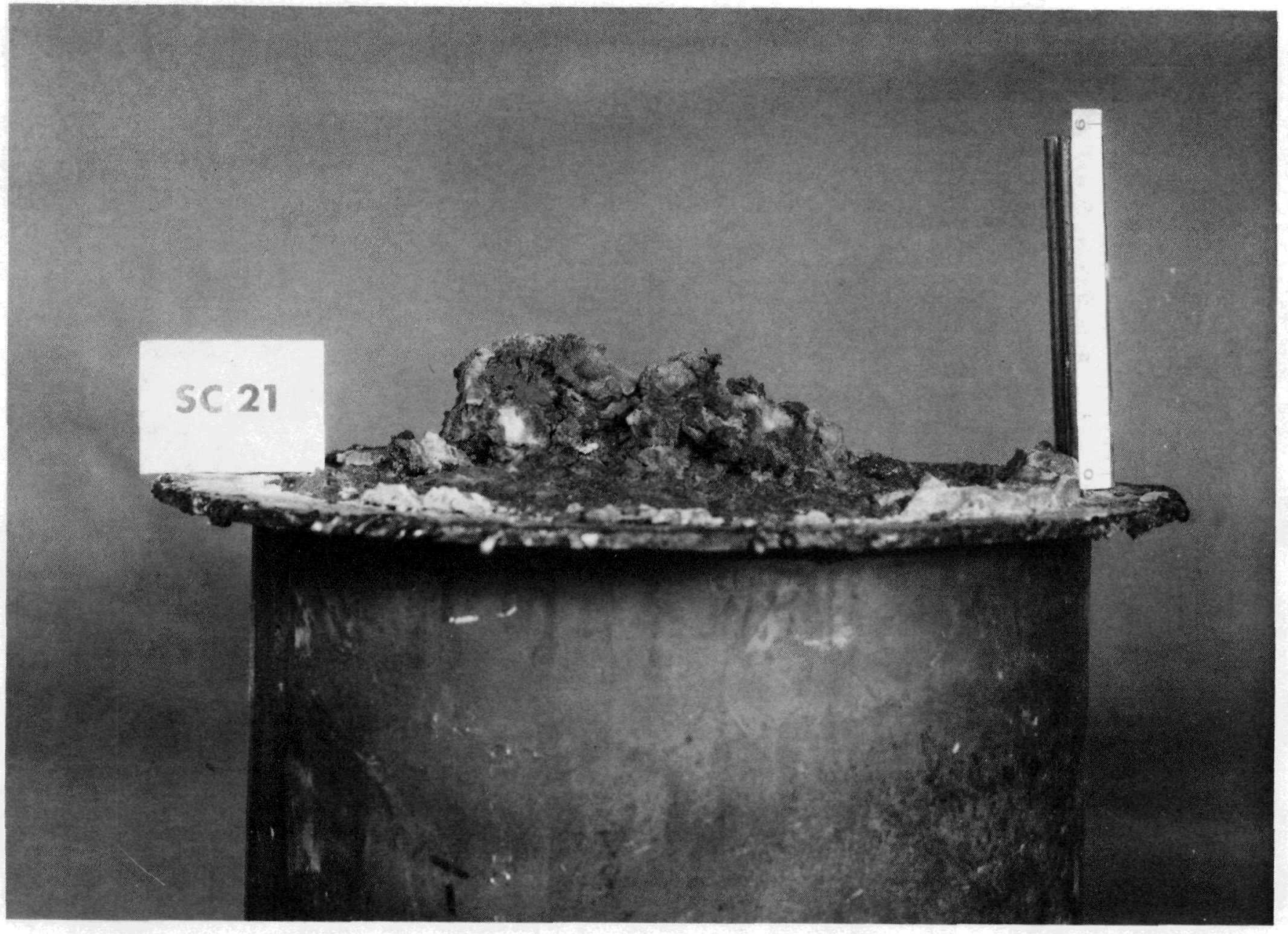

FIGURE 49. Detail of the Reaction Product Mass from Test SC-21. Neg 7804306-27cn 
The brown reaction product mass on the concrete surface adhered tenaciously to the remaining concrete. The specimen was found to have been attacked primarily in the area of the mound of reaction product noted in the center of the specimen. The maximum penetration depth noted was $6.4 \mathrm{~cm}$ (2-1/2 in.) and an average penetration depth of 2.5-cm (1 in.) was observed. The circumferential boundary of the test article was not significantly chemically attacked, but retained little strength. Figure 50 shows a side view of the specimen just after removal of the steel cask surrounding it. Substantial cracking can be seen in the region of the 12.7-cm (5-in.) depth. Figure 51 shows a slightly rotated view of the same region after the reaction product mass was chiselled away. The substantial cracking observed on the right side of the specimen can be seen to follow the cracks observed in the previous photograph. By means of comparison, the penetration observed for this test at $677^{\circ} \mathrm{C}\left(1250^{\circ} \mathrm{F}\right)$ was substantially greater than observed at $510^{\circ} \mathrm{C}\left(950^{\circ} \mathrm{F}\right)$ but less than observed at $871^{\circ} \mathrm{C}\left(1600^{\circ} \mathrm{F}\right)$.

\section{J. TEST DISCUSSION -- TEST SC-22}

Test SC-17 experienced difficulties during the pour which compromised the intention of the test. Therefore, the test was re-run, using a new specimen. Test conditions included $22.6 \mathrm{~kg}(50 \mathrm{lb})$ of sodium at $871^{\circ} \mathrm{C}$ $\left(1600^{\circ} \mathrm{F}\right)$. The basalt sample was maintained at temperature for 24 hours, at which time it was decanted as before.

The target temperature of $871^{\circ} \mathrm{C}\left(1600^{\circ} \mathrm{F}\right.$ ) (seen in Figure 52) was achieved in one hour, but heater failures allowed that level to be maintained for only one additional hour. A $816^{\circ} \mathrm{C}\left(1500^{\circ} \mathrm{F}\right)$ temperature was held to 12 hours into the test, at which time the system slowly cooled to $732^{\circ} \mathrm{C}\left(1350^{\circ} \mathrm{F}\right)$ by the end of the test. The sodium thermocouples a 11 indicated essentially the same readings, with no detail noted other than that attributed to heater operation.

The concrete thermocouple at the $2.5-\mathrm{cm}(1-\mathrm{in}$.$) level showed a rapid$ rise to $732^{\circ} \mathrm{C}\left(1350^{\circ} \mathrm{F}\right)$ in one hour, then reached $816^{\circ} \mathrm{C}\left(1500^{\circ} \mathrm{F}\right)$ at almost the 


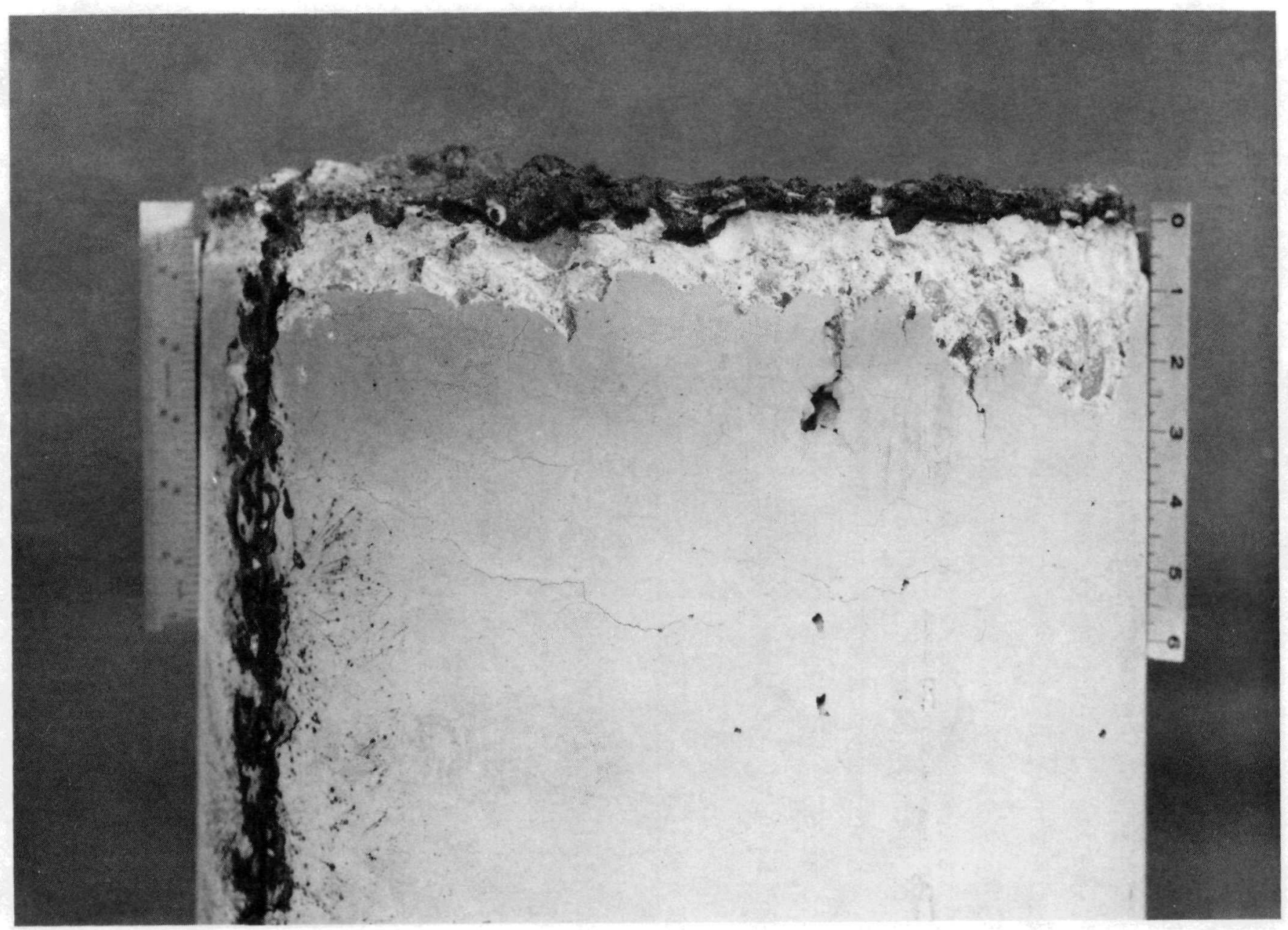

FIGURE 50. Side View of the Test Specimen from Test SC-21. Neg 7804306-25cn 


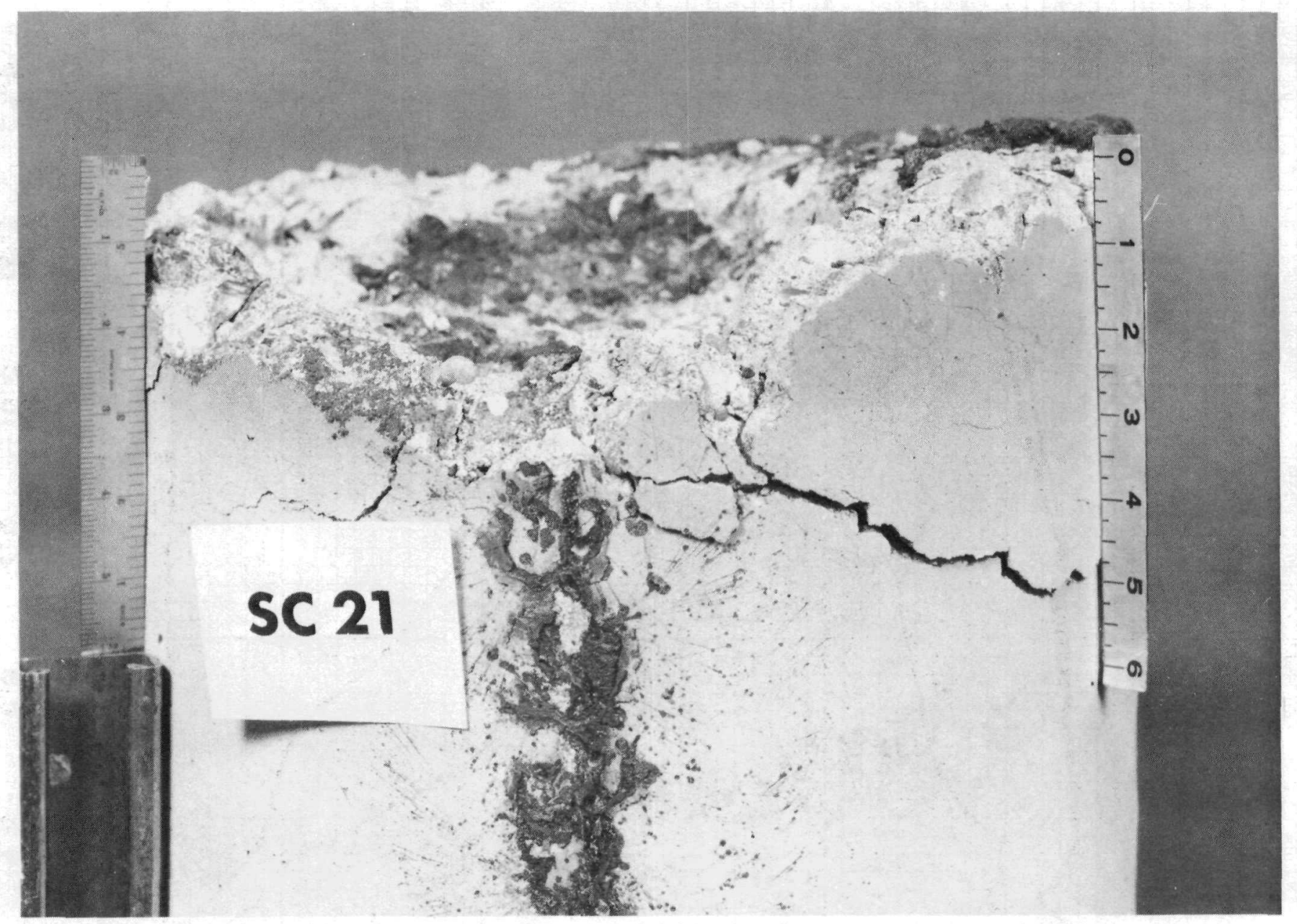

FIGURE 51. Detailing the Observed Penetration and Showing Substantial Cracking of the Specimen. Neg 7804306-8cn 


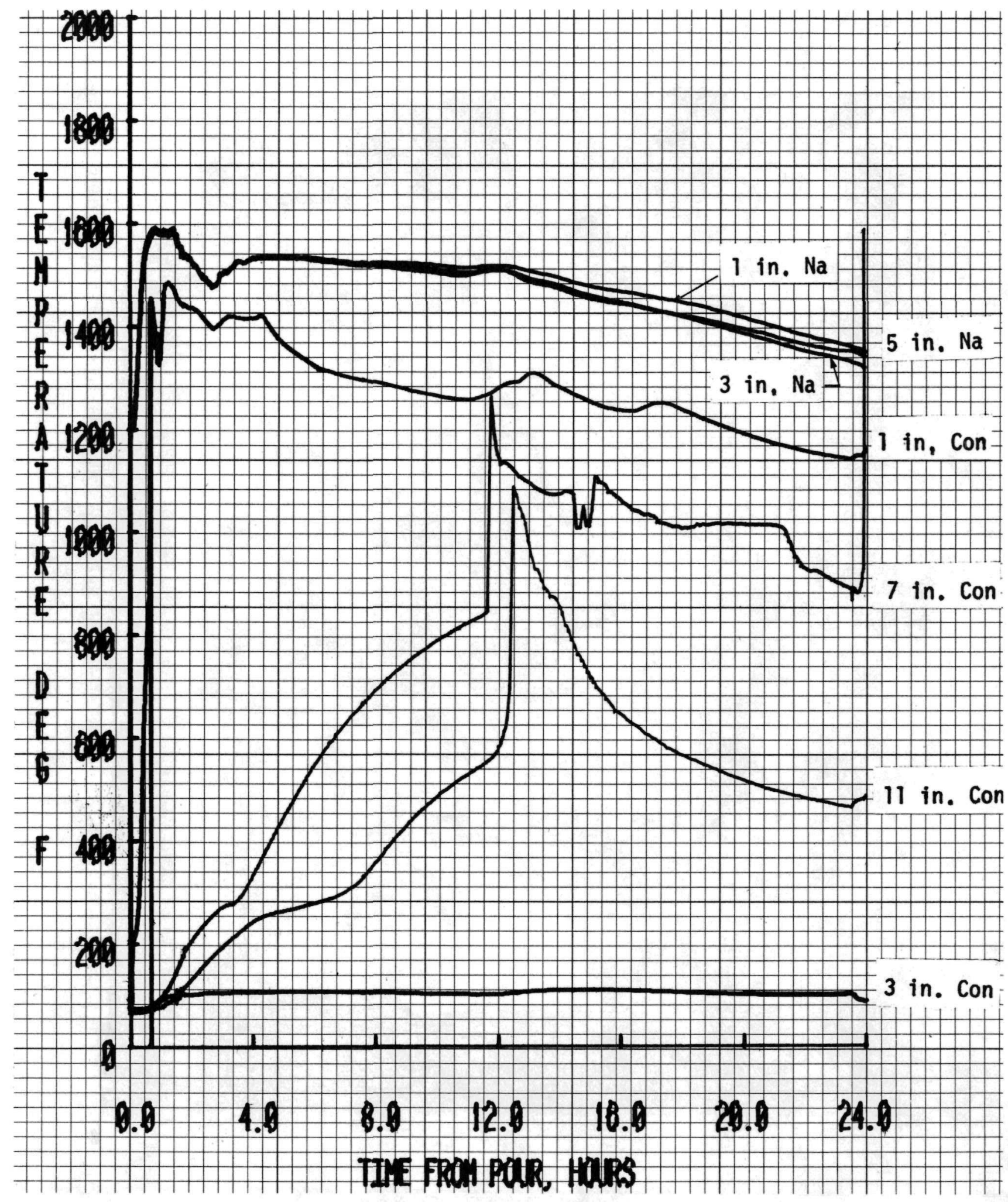

FIGURE 52. SC-22 System Temperatures. 
same time heater failures occurred. Some of the detail observed at that thermocouple location reflected observations made based on the sodium thermocouple data, therefore suggesting that the $2.5-\mathrm{cm}(1-\mathrm{in}$.$) concrete thermo-$ couple was exposed to the pool. The 7.6-cm (3-in.) concrete thermocouple proved faulty and gave no data. The $17.8-\mathrm{cm}(7-$ in.) concrete thermocouple showed a usual conduction response until 11 hours, at which time a sharp, discontinuous rise of $278^{\circ} \mathrm{C}\left(500^{\circ} \mathrm{F}\right)$ was observed, indicating sodium penetration. Similar behavior of the 27.9-cm (11-in.) thermocouple was noted 12 hours into the test. At 12 hours, the cell atmosphere thermocouples reflected an increase in the cell temperature, as did the cell surface temperatures. Both cell pressure and hydrogen concentration responded in a similar manner at 12 hours (Figure 53).

Post-test inspection revealed the severely distorted test specimen shown in Figure 54. Both $\mathrm{fl}$ anges of the concrete specimen were distorted, as was the cask surrounding the concrete. The lower plate was distorted and expansion of reaction products fractured one 8-mm (5/16-in.) bolt and pulled the head of a second through the 3-mm (1/8-in.) lower plate.

Several forms of reaction products were observed in the reservoir. The appearance of the residue (Figure 55) was the same as noted from tests SC-15 and SC-16. A large piece of unreacted concrete adhered to the bulk of the reaction product mass as the residue was removed from the specimen, as shown in Figure 56. The reaction appeared to have penetrated between the cask wall and concrete surface, as suggested by results of tests SC-15 and 16 previously.

Figure 57 shows the specimen after an attempt was made to remove the cask. As can be seen in the photograph, the remaining concrete cleaved into two sections. The sodium penetrated primarily down one section of the wall. The general appearance of the penetrated area was that of the volume left when a cylinder of smaller diameter rests inside a larger cylinder with contact at one spot on the circumference. The sodium penetrated completely through the specimen at the area of "maximum clearance." Discounting the 


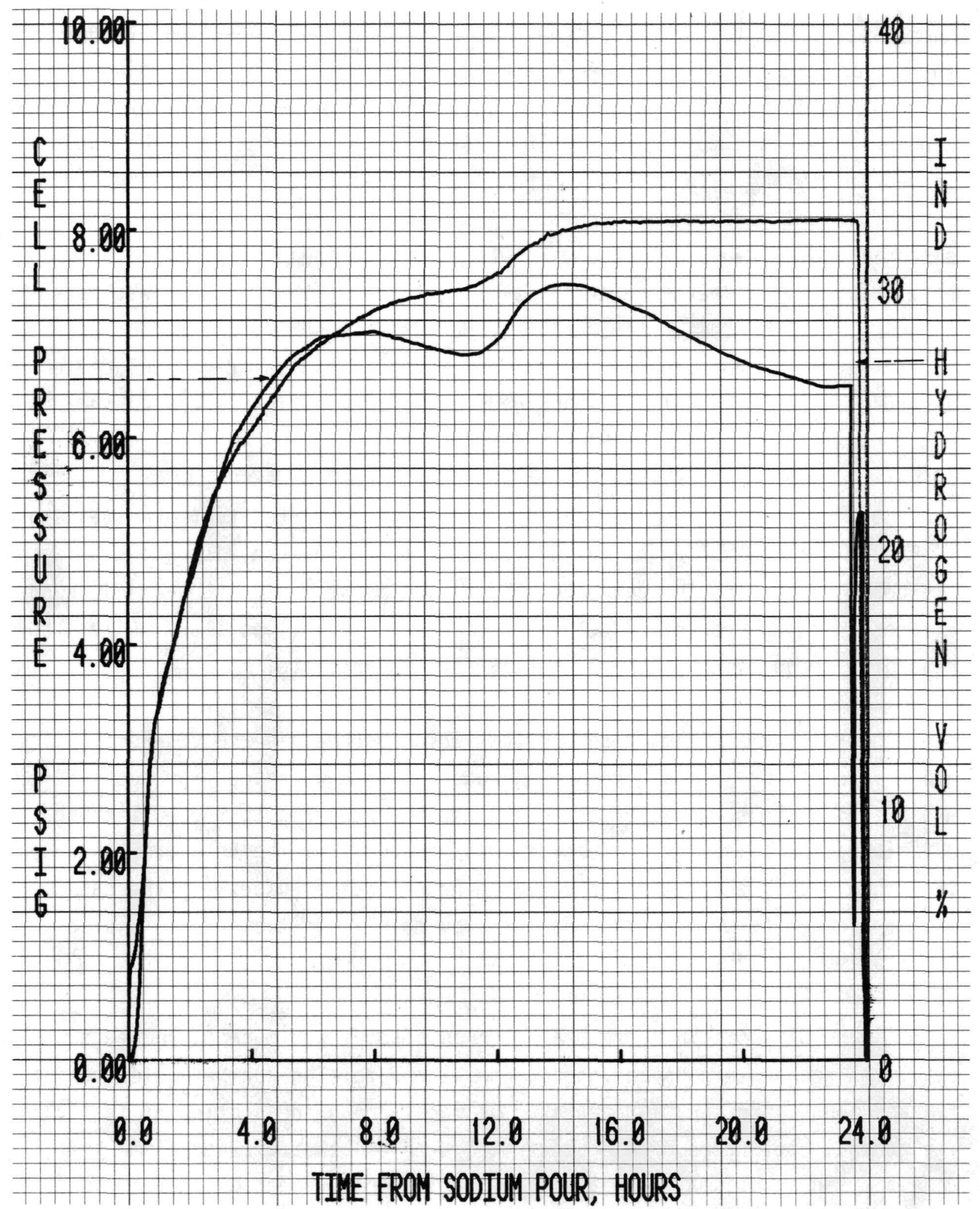

FIGURE 53. SC-22 Cell Pressure and Indicated Hydrogen Concentration. 


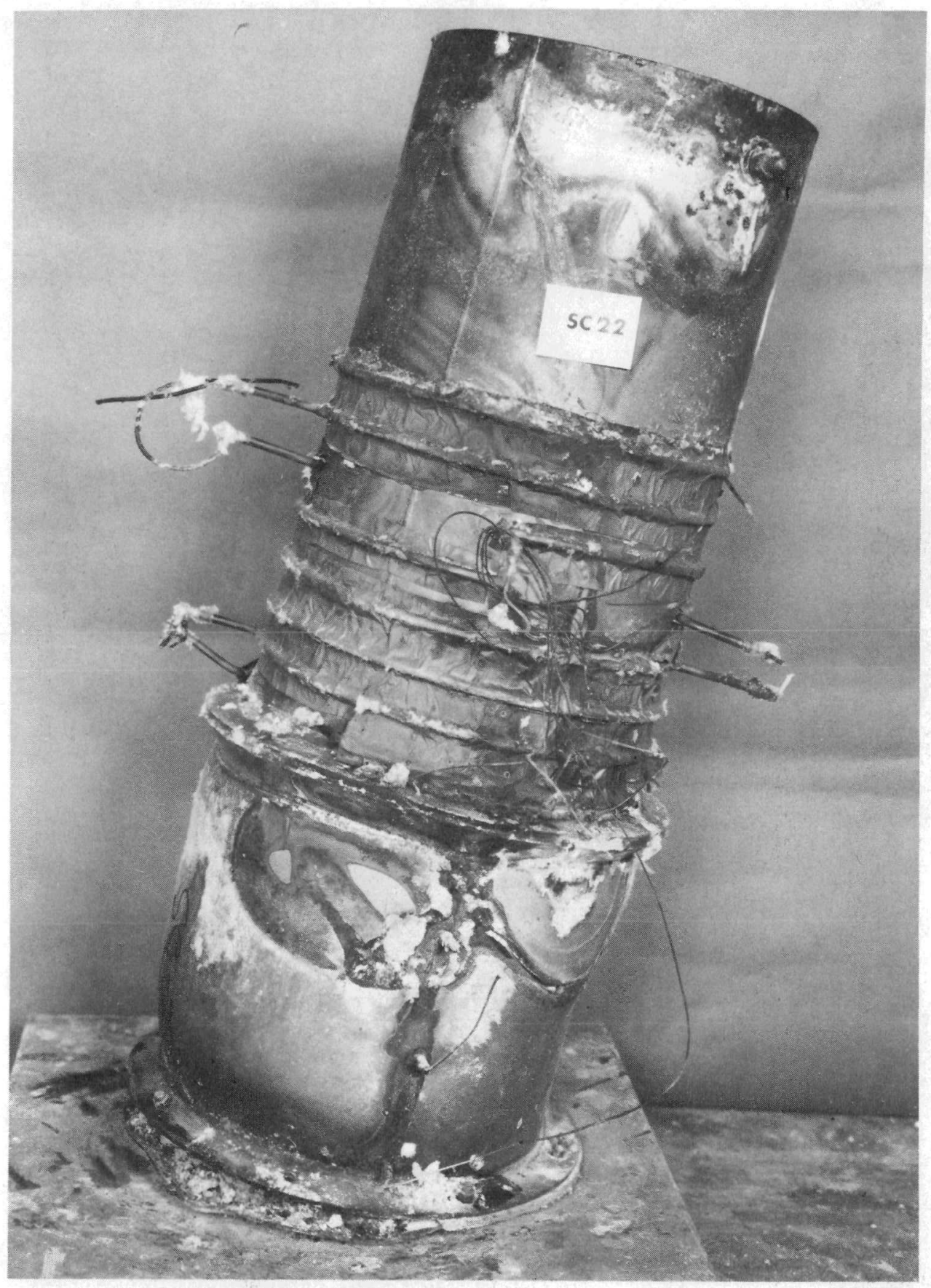

FIGURE 54. General View of the Complete Test Assembly After Removal from the Test Vesse1. Neg 7804306-16cn 


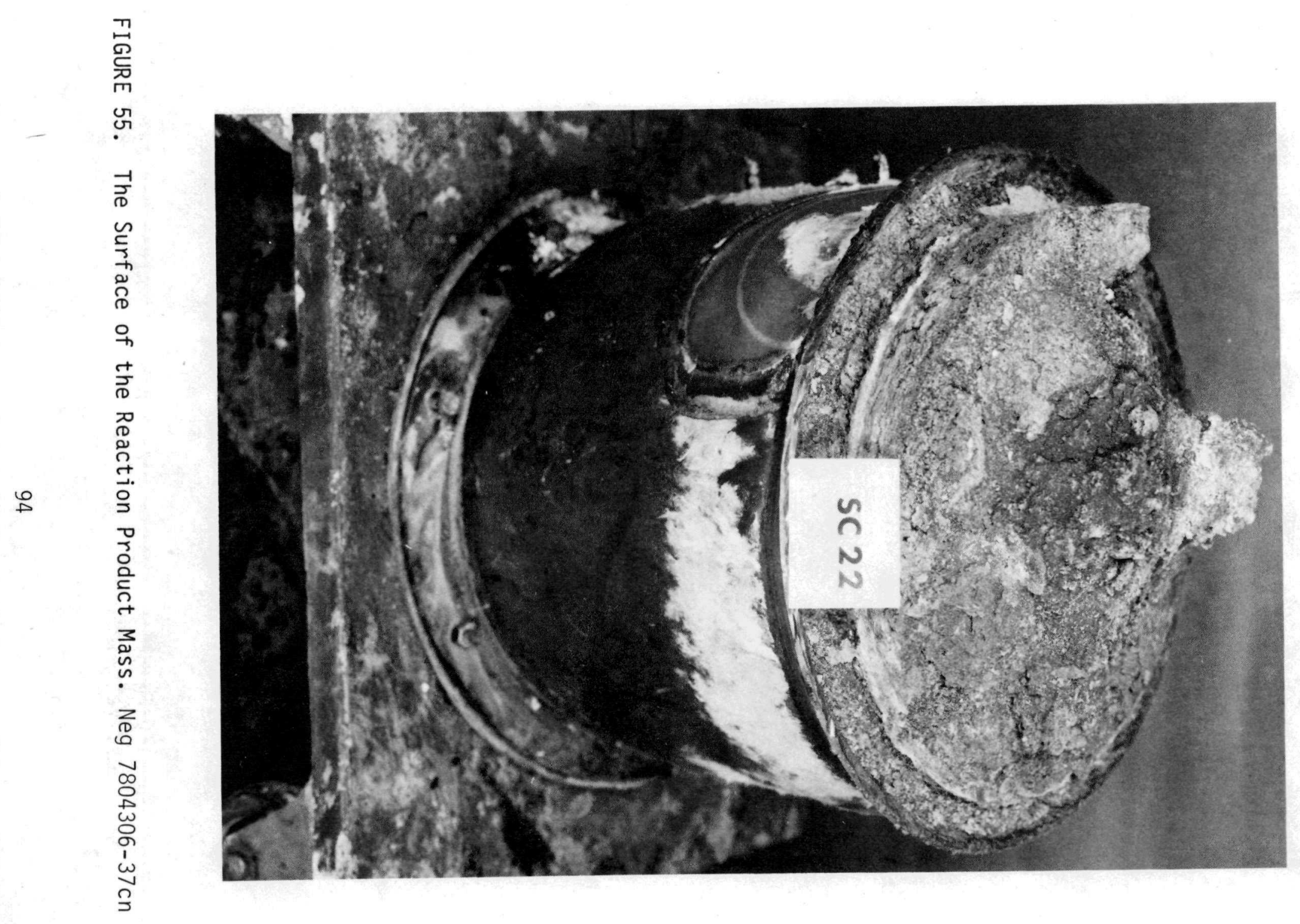

0 . 


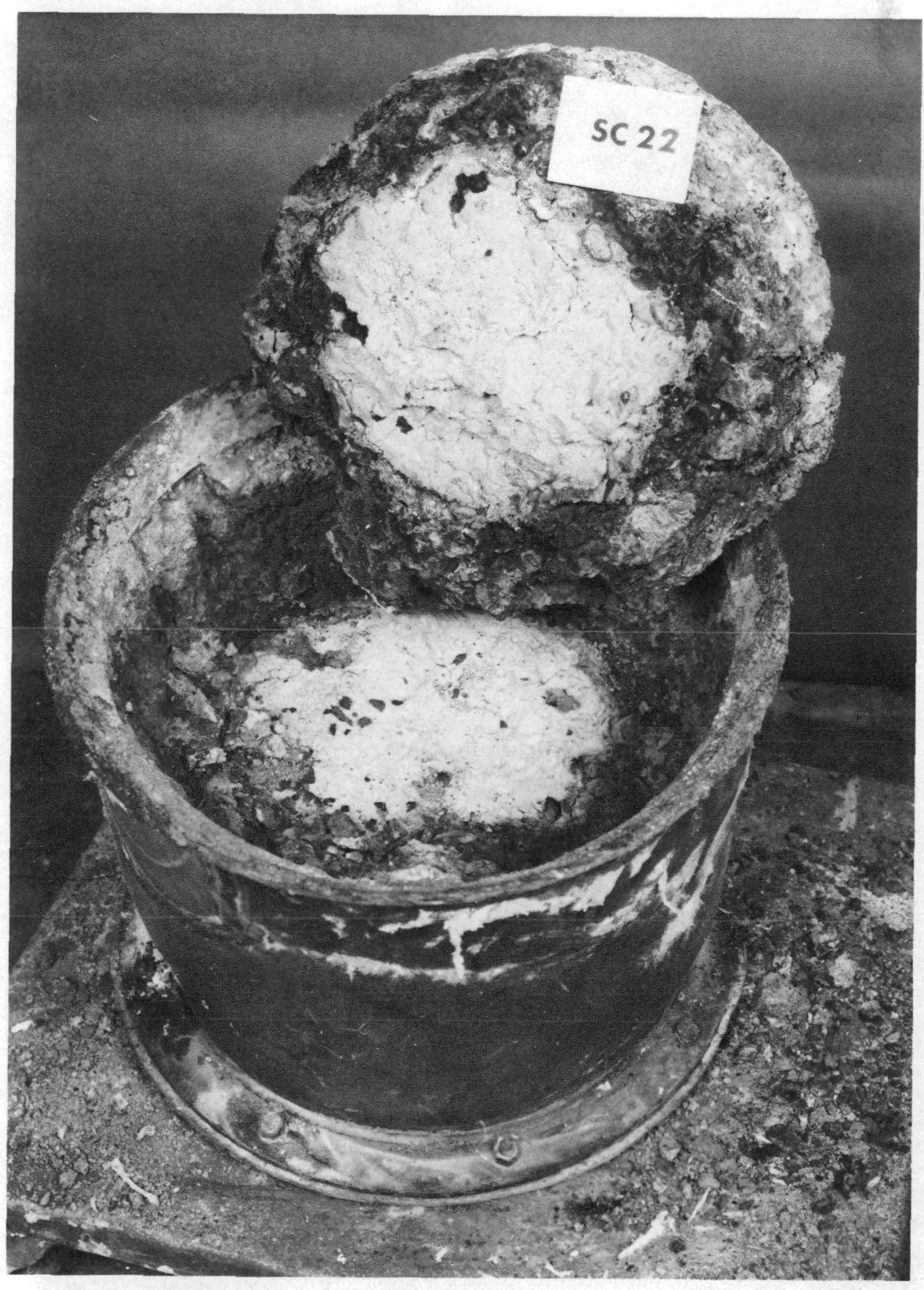

FIGURE 56. The Bottom of the Reaction Product Mass Showing a Section of Unreacted Concrete. Neg 7804306-3cn 


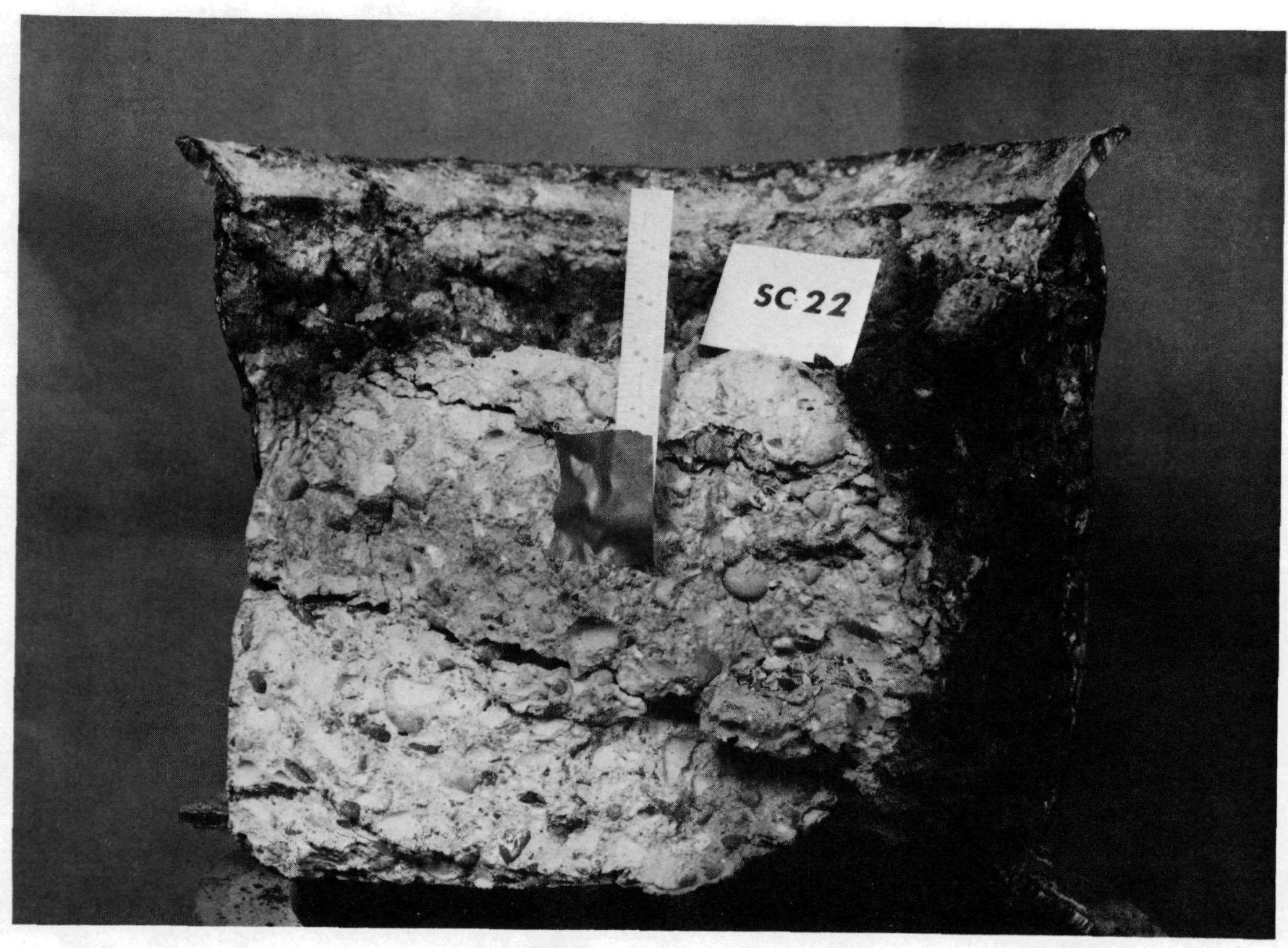

FIGURE 57. A Cross-Section of the Concrete Section of Test SC-22. Neg 7804306-12cn

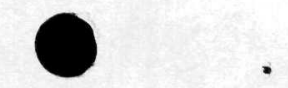


effects of the sidewall penetration, the bulk concrete surface was penetrated to a depth of 6.4 to $7.6 \mathrm{~cm}(2.5$ to $3 \mathrm{in.})$. The piece of chemically unreacted concrete found adhering to the reaction product was $13-\mathrm{mm}(1 / 2-\mathrm{in}$.) thick, representing the apparent range of penetration. Including the chunk as unreacted concrete gives a depth of $6.4 \mathrm{~cm}(21 / 2 \mathrm{in.})$. Accounting for it as reacted concrete gives a bulk penetration of $7.6 \mathrm{~cm}$ ( $3 \mathrm{in.}$ ). 
$\bullet$

98 


\section{SUMMARY OF OBSERVED PENETRATIONS}

Previous paragraphs described the penetrations observed for each of the tests. Those penetrations were obtained from both direct visual observations and from photographs of the test articles taken during the disassembly and inspection.

The photographs provided the most convenient means for evaluating the average penetration. The average depth of penetration was estimated during inspection. The camera was then set up with the lens axis at the plane of average penetration. The camera was carefully arranged to minimize either distortion or foreshortening of the plane at the estimated average depth. Rulers were included to allow direct scaling from the photograph.

Photographs were taken from several angles around the specimen. The average penetration was determined for each view and the results weighted according to a degree of confidence associated with each view. Some views had little significance if other views showed details such as large cavities hidden in one particular photograph.

The results of these estimates are summarized in Tables 11 and 12 . The average penetration estimates are accurate to within $3 \mathrm{~mm}$ ( $1 / 8 \mathrm{in}$.) for penetrations less than $5.1 \mathrm{~cm}$ (2 in.) and about $6 \mathrm{~mm}$ (1/4 in.) for penetration greater than $5.1 \mathrm{~cm}$ (2 in.). Maximum penetrations were measured during inspection and are accurate to $3 \mathrm{~mm}(1 / 8 \mathrm{in.})$ in general.

In order to estimate the longer term penetration depths, the basalt data obtained were curve-fitted to a functional form:

$$
x=a_{1}\left(1-e^{-a_{2} t}\right)
$$




\section{TABLE 11}

SUMMARY OF AVERAGE PENETRATIONS

\begin{tabular}{|c|c|c|c|c|c|c|}
\hline $\begin{array}{c}\text { Test } \\
\text { Number }\end{array}$ & $\begin{array}{l}\text { Time } \\
(\mathrm{hr})\end{array}$ & $\begin{array}{l}\text { Temp } \\
(\mathrm{O} C)\end{array}$ & $\begin{array}{c}\text { ature } \\
\text { (OF) }\end{array}$ & $\begin{array}{l}\text { Aver } \\
\text { Penet } \\
(\mathrm{cm})\end{array}$ & $\begin{array}{l}\text { ge } \\
\text { (in.) } \\
\text { (ion }\end{array}$ & Concrete \\
\hline 13 & $24+2$ & 871 & 1600 & 4.4 & 1.75 & Limestone $+\mathrm{NaOH}$ \\
\hline 14 & 24 & 871 & 1600 & 5.7 & 2.25 & Limestone $+\mathrm{NaOH}$ \\
\hline 15 & 2 & 871 & 1600 & 3.2 & 1.25 & Basalt \\
\hline 16 & 8 & 871 & 1600 & 7.0 & 2.75 & Basalt \\
\hline 17 & 24 & 871 & 1600 & 5.7 & 2.25 & Basalt \\
\hline 18 & 8 & 871 & 1600 & 2.5 & 1.0 & Limestone $+\mathrm{NaOH}$ \\
\hline 19 & 8 & 677 & 1250 & 3.8 & 1.5 & " Chunks " \\
\hline 20 & 8 & 510 & 950 & 0.6 & 0.25 & Basalt $+\mathrm{NaOH}$ \\
\hline 21 & 8 & 677 & 1250 & 2.5 & 1.0 & Basalt $+\mathrm{NaOH}$ \\
\hline 22 & 24 & 871 & 1600 & $6.4-7.6$ & $2.5-3.0$ & Basalt \\
\hline
\end{tabular}


TABLE 12

SUMMARY OF MAXIMUM PENETRATIONS

\begin{tabular}{|c|c|c|c|c|c|c|}
\hline $\begin{array}{l}\text { Test } \\
\text { Number }\end{array}$ & $\begin{array}{l}\text { Time } \\
\text { (hr) }\end{array}$ & $\begin{array}{l}\text { Temp } \\
\left({ }^{\circ} \mathrm{C}\right)\end{array}$ & $\begin{array}{l}\text { ature } \\
(\mathrm{OF})\end{array}$ & $\begin{array}{c}\text { M } \\
\text { Pen } \\
(\mathrm{cm}) \\
\end{array}$ & $\begin{array}{l}\text { ion } \\
\text { (in.) } \\
\text { ion }\end{array}$ & Concrete \\
\hline 13 & $24+2$ & 871 & 1600 & 7.6 & 3 & Limestone $+\mathrm{NaOH}$ \\
\hline 14 & 24 & 871 & 1600 & 8.4 & 3.3 & $"$ \\
\hline 15 & 2 & 871 & 1600 & 15.2 & 6 & Basalt \\
\hline 16 & 8 & 871 & 1600 & 22.9 & 9 & $"$ \\
\hline 17 & 24 & 871 & 1600 & 6.4 & 2.5 & $"$ \\
\hline 18 & 8 & 871 & 1600 & 4.4 & 1.75 & Limestone $+\mathrm{NaOH}$ \\
\hline 19 & 8 & 677 & 1250 & 5.7 & 2.25 & " Chunks \\
\hline 20 & 8 & 510 & 950 & 0.6 & 0.25 & $\mathrm{Basalt}+\mathrm{NaOH}$ \\
\hline 21 & 8 & 677 & 1250 & 6.4 & 2.5 & $"$ \\
\hline 22 & 24 & 871 & 1600 & 30.5 & 12 & Basalt \\
\hline
\end{tabular}


This function was arrived at by assuming the following:

- In the absence of effects such as spalling, reaction due to early water release, or retardation due to reaction product accumulation, the rate of reaction was assumed constant so that

$$
\frac{\mathrm{dX}}{\mathrm{dt}}_{\text {basic }}=\mathrm{C}_{1} \text {, a constant. }
$$

- The retardation effects of reaction-produced accumulation were assumed to be linear, i.e., a 1-in. layer retards the bulk reaction rate twice as effectively as a $1 / 2-i n$. layer, so that:

$$
\frac{d x}{d t} \underset{\text { product }}{ }=-c_{2} x \text {, }
$$

where $C_{2}$ is a constant and the accumulation of products is directly proportional to the total reaction, $x$.

- The short time effects caused by spaliing, etc., can be ignored for purposes of determining the long term penetration. This assumption holds for long term, since the short term increases in penetration result in a greater accumulation in reaction products, providing a feedback which is negative.

These three assumptions produce a differential equation for reaction rate (i.e., penetration depth) of the form

$$
\frac{d x}{d t}=c_{1}-c_{2} x
$$

which has the solution:

$$
x=a_{1}+a_{3} e^{-a_{2} t} .
$$


The boundary condition at $t=0, x=0$ provides for $a_{1}=-a_{3}$ and the condition that $X$ is always positive (concrete is consumed) provides that $a_{3}$ is negative. Hence, the solution can be rewritten as

$$
x=a_{1}\left(1-e^{-a_{2} t}\right)
$$

The basalt data were fitted to this function form using the method of differential corrections, and plotted as shown on Figure 58 . The coefficients and the standard error of measurement $\left(s=r_{j}^{2} / n\right)$ are given in Table 13. Also shown on the figure and in the table are the results of previous tests with magnetite and limestone. In addition, the tests with sodium hydroxide are included on the figure for comparisons.

No attempt has been made to provide a more detailed model of the penetration kinetics. The current model appears reasonable in light of the horizontal data thus far obtained. There are insufficient data to provide any real rate-law to the vertical data ${ }^{(1)}$, particularly due to the inherent differences of the formation of an inhibiting reaction product layer.

Better definition of the characteristics of the penetration rate/time dependence will require tests performed on much longer time scales (on the order of 100 hours).

Earlier efforts, described in the literature review ${ }^{(1)}$, indicated the equation for the specific reaction rate to be:

$$
R / A=0.0125 t^{-0.75}
$$

Integrating this equation and substituting the $1 \mathrm{ft}^{2}$ surface area of this test series gives, for the penetration,

$$
x=0.6 t^{0.25}
$$

The curve generated by this expression is also shown on Figure 58 . 


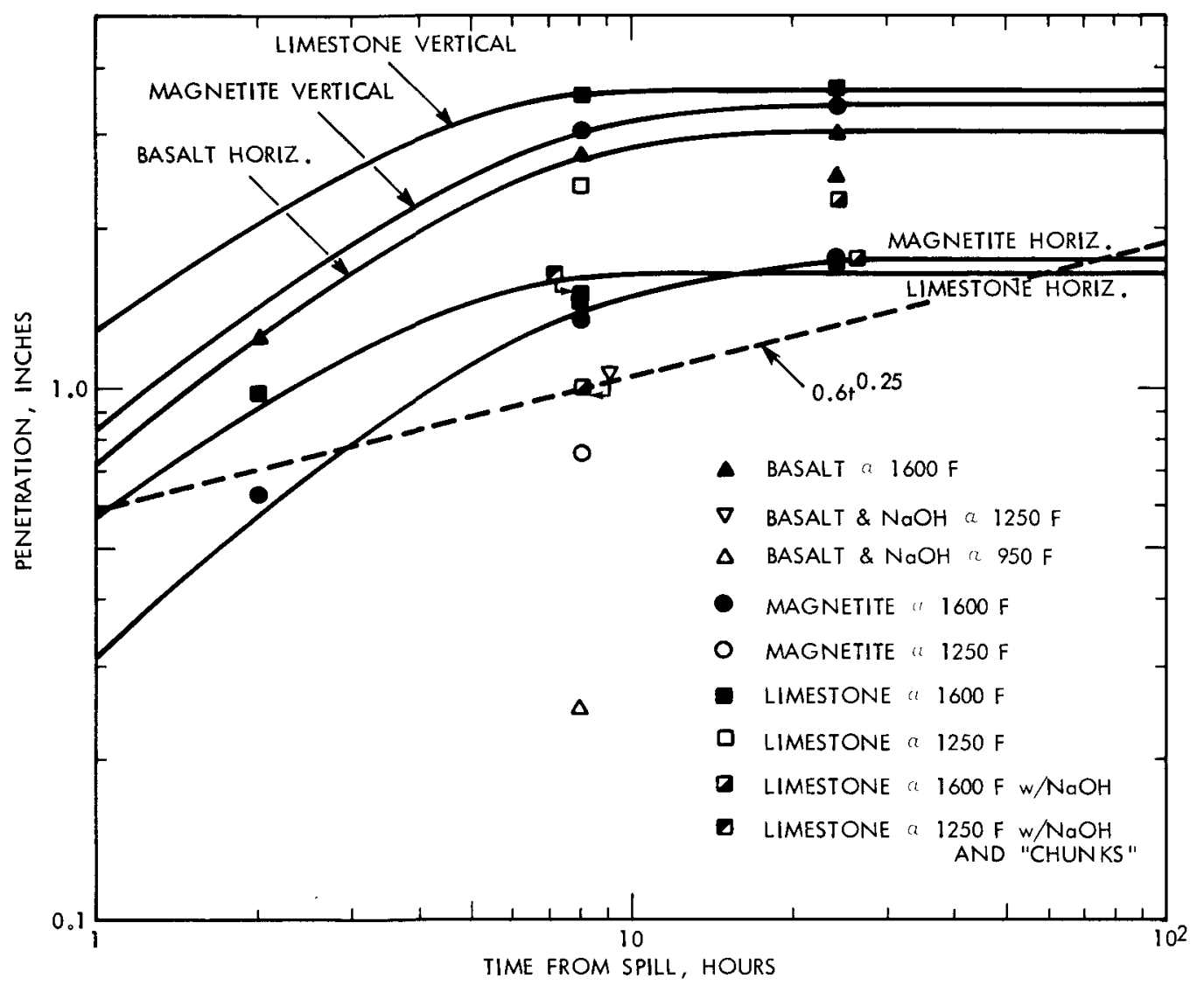

HEDL 7908-173.1

FIGURE 58. Sodium Hydroxide Penetration into Concrete. 
TABLE 13

\section{CURVE FIT* PARAMETERS FOR \\ PENETRATION DEPTH DATA}

\begin{tabular}{|c|c|c|c|c|c|}
\hline $\begin{array}{c}\text { Concrete } \\
\text { Type } \\
\end{array}$ & Orientation & $\begin{array}{c}\text { Number } \\
\text { of } \\
\text { Points } \\
\end{array}$ & $a_{1}$ & a2 & $s$ \\
\hline Magnetite ${ }^{+}$ & Horizontal & 3 & 1.754 & .1968 & .047 \\
\hline Limestone $^{+}$ & Horizontal & 3 & 1.638 & .4247 & .078 \\
\hline Magnetite ${ }^{+}$ & Vertical & 2 & 3.39 & .283 & $10^{-12}$ \\
\hline Limestone $^{+}$ & Vertical & 2 & 3.61 & .448 & $10^{-12}$ \\
\hline Basalt & Horizontal & 3 & 3.05 & .267 & .077 \\
\hline \multicolumn{6}{|c|}{ * Curve fit to $x=a_{1}(1-\exp -2 t)$} \\
\hline \multicolumn{6}{|c|}{$a_{1}$ in inches } \\
\hline$a_{2}$ in $h r^{-1}$ & & & & & \\
\hline
\end{tabular}

+Ref erence 1 . 
•

.

106

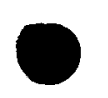




\section{RELEASE OF GASEOUS REACTION PRODUCTS}

On-line analyses for three gaseous reaction products were performed. These included hydrogen, oxygen, and water vapor. Strictly speaking, oxygen is not a product of the reaction, but on-line monitoring was maintained due to the safety aspects related to hydrogen accumulation.

Detection methods for these gases were covered in a previous section of this report.

Several points are worth noting immediately.

- Due to the lengthy sample lines and occasionally cool environment of those lines relative to reaction cell temperatures, little weight was $\mathrm{placed}$ on the water vapor readings. The indicators did demonstrate, however, that the moisture content of the cell atmosphere decreased during the test period.

- Sensitivity of the hydrogen meter was dependent, in part, on cell pressure, temperature, oxygen content, etc.

Data pertinent to the evaluation of released gases included the cell volume, $14.2 \mathrm{~m}^{3}\left(500 \mathrm{ft}^{3}\right)$, the ce 11 pressure, and temperature readings. These data, along with the gas concentrations (in mole or volume concentrations) provide, using the ideal gas law, an estimate of the gas released during the monitored period.

The amount of hydrogen accumulated in the cell was estimated in two ways. First, the total number of moles of gas in the cell was calculated at both the start of the test and at the time immediately prior to the purge. The difference between the gas volumes at these times is attributed to hydrogen accumulation. Second, the molar gas content of the cell prior to the purge was multiplied by the hydrogen concentration indicated by instrumentation. This second figure was generally higher than the first, indicating that cell leakage was important, particularly for tests SC-14 and SC-15. 
Review of the data showed that hydrogen was the only gas released in sufficient quantity to be of detailed interest. Tables 14 and 15 summarize the basic cell environmental data and the hydrogen accumulated during the monitored time (test time less $1 / 2$ hour). Figure 59 is a sumary of the calculated hydrogen release as a function of test time. Included on the figure is a flaired line indicating the hydrogen released from the basalt tests.

Table 15 also compares the hydrogen detected in the cell with the total hydrogen content (as water) in the original $1 \mathrm{ft}^{3}$ concrete samples. 
TABLE 14

ESTIMATE OF HYDROGEN RELEASE DATA

\begin{tabular}{|c|c|c|c|c|c|c|}
\hline \multirow{2}{*}{$\begin{array}{l}\text { Test } \\
\text { Number }\end{array}$} & \multicolumn{2}{|c|}{$\begin{array}{l}\text { Mean Cell } \\
\text { Temperature (OF) }\end{array}$} & \multicolumn{2}{|c|}{$\begin{array}{c}\text { Cell Pressure } \\
\text { (psig) }\end{array}$} & \multicolumn{2}{|c|}{$\begin{array}{c}\mathrm{H}_{2} \text { Concentration } \\
(\text { vol } \%)\end{array}$} \\
\hline & $t_{0}$ & $t_{f}-30 \mathrm{~min}$ & Peak & $t_{f}-30 \min$ & Peak & $t_{f}-30 \mathrm{~min}$ \\
\hline SC -13 & $N A$ & $N A$ & 7.8 & 3.2 & & \\
\hline 14 & 84 & 94 & 1.74 & 0.98 & 33.8 & 33.0 \\
\hline 15 & 61 & 128 & 3.2 & 3.2 & 16.9 & 16.9 \\
\hline 16 & 64 & 105 & 8.4 & 8.4 & 29.4 & 29.4 \\
\hline 17 & 71 & 111 & 8.5 & 9.1 & 30.3 & 29.7 \\
\hline 18 & 74 & 113 & 6.2 & 6.2 & 25.8 & 25.8 \\
\hline 19 & 70 & 93 & 6.1 & 6.1 & 22.0 & 22.0 \\
\hline 20 & 70 & 83 & 2.6 & 2.6 & 11.1 & 11.1 \\
\hline 21 & 72 & 95 & 4.4 & 4.4 & 25.5 & 25.5 \\
\hline 22 & 73 & 106 & 7.5 & 6.5 & 32.1 & 32.4 \\
\hline
\end{tabular}




\section{TABLE 15}

\section{CELL HYDROGEN CONTENT}

Test Start Finish Number \#moles \#moles

13

14

15

16

17

18

19

20

21

22
NA

NA

1.32

1.42

1.90

1.94

1.70

1.75

1.48

1.60

1.75

$\frac{\begin{array}{c}\mathrm{H}_{2} \\ \text { moles }\end{array}}{N A} \frac{\% \quad \begin{array}{c}\mathrm{H}_{2} \\ \mathrm{~N}_{f} \# \text { moles }\end{array}}{N A}$

0.06

0.44

0.11

0.24

0.56

0.58

0.44

0.39

0.16

0.41

0.57
Est imated $\mathrm{H}_{2}$ Released

$\% \mathrm{H}_{2}$ Released $/ \mathrm{H}_{2}$ in Original Specimen Min Max

$\begin{array}{rl}6.1 & 44.6 \\ 11.1 & 24.3 \\ 59.7 & 56.7 \\ 58.7 & 65.8 \\ 42.5 & 44.6 \\ 46.6 & 39.5 \\ 16.2 & 19.2 \\ 31.4 & 41.5 \\ 36.5 & 57.7\end{array}$




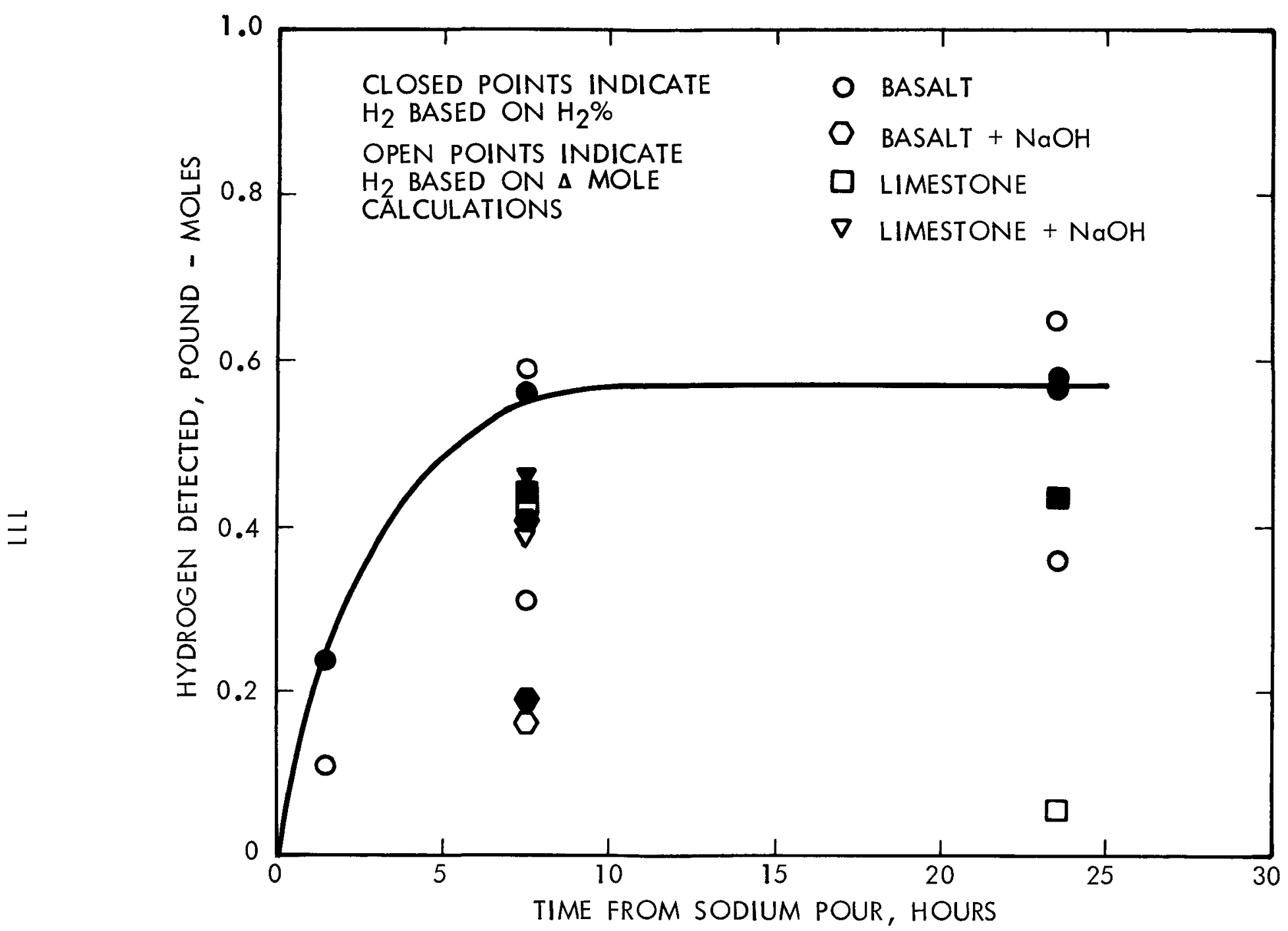

FIGURE 59. Hydrogen Released Data.

HEDL $7908-173.3$ 


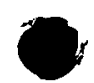

,

n

1

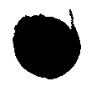

112 


\section{REFERENCES}

1. J. A. Hassberger, Intermediate Scale Sodium-Concrete Reaction Tests, HEDL-TME 77-99, Hanford Engineering Development Laboratory, Richland, WA, April 1973.

2. C. T. Nelson, "Sodium-Concrete Reaction Experiments," TR-095-900-001, Atomics International, February 25, 1972.

3. J. A. Hassberger, R. K. Hilliard, and L. D. Muhlestein, SodiumConcrete Reaction Tests, HEDL-TME 74-36, Hanford Engineering Development Laboratory, Rich land, WA, June 1974.

4. R. E. Witkowski, and R. G. Charles, "A Preliminary Chemical Investigation of Sodium-Concrete Reactions by Differential Thermal Analysis, " presented at the International Conference on Liquid Metal Technology in Energy Production, Champion, PA, May 1976.

5. R. K. Hilliard, "Sodium-Concrete Reactions Liner Response, and Sodium Fire Extingu ishment," HEDL-SA-983, paper presented in "Status of Safety Technology for Radiological Consequence Assessment of Postulated Accidents in LMFBR," ERDA-56, July 1975.

6. C. C. Addison, M. G. Barker, and R. J. Fulham, "Reactions of Liquid Sodium with Transition Metal Oxides, Part III," J. Chem. Soc (A), p. $4483,1965$.

7. C. C. Addison, M. G. Barker, R. M. Lintonbon, and R. J. Fulham, "Reactions of Liquid Sodium with Transition Metal 0xides, Part III," J. Chem. Soc $(A)$, p. 2457, 1969.

8. R. G. Charles, and P. H. Biggs, "Thermomagnetic Analys is and Calorimetric Studies of the Reaction of Ferric 0xide and Liquid Sodium," in Chemical Aspects of Corrosion and Mass Transfer in Liquid Sodium, S. Jansson, Ed., The Metallurgical Society of AIME, New York, p. 381, 1973.

9. R. G. Charles, "Differential Thermal Analysis as a Means for Studying Chemical Reactions in Liquid Sodium," Trans. Am. Nuclear Soc. 19, p. 107,1974 .

10. R. G. Char les, and P. G. Haver lock, "Magnetic Susceptibility Measurements for Following Reactions in Liquid Sodium," Trans. Am. Nuclear Soc. 12(1), p. 122,1969.

11. J. A. Hassberger, et a1., "Reactions of Sodium with Various Concretes and Concrete Materials," HEDL-SA-1118, paper presented at the Safety Technology Meeting for the Nuclear Regulatory Commission on Inherent Retention, Bethesda, MA, September 27, 1976. 
12. R. E. Witkowski, et al., "A Chemical Investigation of Sodium-Concrete Reactions," Report Number 77-8B6-NACON-R1, Westinghouse Research Laboratories, Pittsburgh, PA 15235.

13. S. A. Meacham, "The Interactions of Tennessee Limestone Aggregate Concrete with Liquid Sodium," WARD-D-0141, December 1976.

14. J. K. Fink, et a 1., "Interactions of Refractories and Reactor Materials with Sodium," Trans. Am. Nucl. Soc., June 1976.

15. D. L. King, et a1., "Sodium Interaction with Limestone Conrete Test Reports," Trans. Am. Nuc 1. Soc., p. 528, 1977.

16. J. E. Smaardyk, et a 1., "Large Scale Sodium Interactions with Concrete," Trans. Am. Nuc 1. Soc., p. 528, 1977.

17. D. L. King, et al., "Large Scale Sodium Test Facility at Sandia Laboratories," PAHR Information Exchange, Argonne National Laboratory, November 1977. 


$$
\text { UC }-79
$$$$
\text { UC-79a (24) }
$$$$
\text { UC-79b (37) }
$$$$
\text { UC }-79 p \quad(35)
$$$$
\text { Argonne National Laboratory (FBR/TMC) }
$$$$
9700 \text { South Cass Avenue }
$$$$
\text { Argonne, IL } 60439
$$

DOE/FFTFPO

Director

DOE / RRT HQ (2)

MaiT Stop B-107

Washington, DC 20545

HEDL (38)

$\begin{array}{lr}\text { GR Armstrong } & W / C-79 \\ \text { JM Atwood } & W / C-45 \\ \text { JW Barreca } & W / 221 T \\ \text { FJ Carvo } & W / 221 T \\ \text { RP Colbum } & W / 221 T \\ \text { VW Cook } & W / 221 T \\ \text { JA Hassberger } & \text { (2) W/E-19 } \\ \text { RK Hilliard } & W / 221 T \\ \text { AR Hinckley } & W / 221 T \\ \text { DL Jeppson } & W / 221 T \\ \text { JD McCormack } & W / 221 T \\ \text { MW McCormick } & W / 221 T \\ \text { GT McDonald } & W / 221 T \\ \text { SE Myers } & W / 221 T \\ \text { LD Muhlestein } & \text { (2) W/221T }\end{array}$

GW Oblisk

RK Owen

BA Parker

RD Peak

RE Peterson

CT Schaede 1

ER Selle

DE Simpson

RM Steele

DD Stepnewski

AE Waltar

RW Wi erman

BV Winkle

WH Yunker

Central Files

Publ Services
$W / 221 T$

$W / 221 T$

$W / 221 T$

$W / C-75$

$W / C-80$

W/A-46

$W / 221 T$

W/E-14

$W / 221 T$

$w / C-75$

$W / C-79$

$W / 221 T$

W/B-14

$W / C-53$

(5) $W / C-110$
(2) $W / C-115$

Distr-1 